\title{
Smoking and dose-dependent early effects of nicotine on bone mechanical properties and histology
}

\author{
Daniel Shaw Porter \\ West Virginia University
}

Follow this and additional works at: https://researchrepository.wvu.edu/etd

\section{Recommended Citation}

Porter, Daniel Shaw, "Smoking and dose-dependent early effects of nicotine on bone mechanical properties and histology" (2004). Graduate Theses, Dissertations, and Problem Reports. 1508. https://researchrepository.wvu.edu/etd/1508

This Thesis is protected by copyright and/or related rights. It has been brought to you by the The Research Repository @ WVU with permission from the rights-holder(s). You are free to use this Thesis in any way that is permitted by the copyright and related rights legislation that applies to your use. For other uses you must obtain permission from the rights-holder(s) directly, unless additional rights are indicated by a Creative Commons license in the record and/ or on the work itself. This Thesis has been accepted for inclusion in WVU Graduate Theses, Dissertations, and Problem Reports collection by an authorized administrator of The Research Repository @ WVU. For more information, please contact researchrepository@mail.wvu.edu. 
Smoking and Dose Dependent Early Effects of Nicotine on Bone Mechanical Properties and Histology

\section{Daniel Shaw Porter}

Thesis submitted to the College of Engineering and Mineral Resources at West Virginia University in partial fulfillment of the requirements for the degree of

Master of Science

in

Mechanical Engineering

Timothy Norman, Ph. D., Chair

Nilay Mukherjee, Ph. D.

Charles Stanley, Ph. D.

Department of Mechanical Engineering and Aerospace Engineering

Morgantown, West Virginia

2004

Keywords: Bone, Nicotine, Fracture Toughness, Smoking

Copyright 2004 Daniel Shaw Porter 


\section{ABSTRACT \\ Smoking And Dose Dependent Early Effects Of Nicotine On Bone Mechanical Properties And Histology}

\section{Daniel Shaw Porter}

The objective was to study the effects of nicotine and cigarette smoke on mechanical properties of cortical bone. Experiments were conducted for 5 weeks with New Zealand White Rabbits. The first experiment of 18 rabbits studied the effect of nicotine levels delivered via a nicotine patch $(5.25,10.5,21 \mathrm{ng} / \mathrm{ml})$, measured by different mechanical tests, porosity, and composition. There was no significant difference between the control and the treatment groups.

The second experiment of 26 rabbits studied the effects of nicotine delivered via a nicotine patch $(10.5 \mathrm{ng} / \mathrm{ml})$ and via a smoking chamber on fracture toughness and porosity. The rabbits exposed to the smoke for 5 weeks had significantly lower fracture toughness values when compared to the different groups (exposed to smoke for 4 weeks group, nicotine group, and the control group). This suggests that other agents besides nicotine are responsible for the weakening of bone clinically seen in smokers. 


\section{Acknowledgement}

I would like to thank Dr. Timothy Norman for giving me this chance to work in the lab and under his guidance. I would like to thank Dr. Norman and Dr. Mukherjee for their advice during this project, as well as, Dr. Stanley for his help. I would like to thank Vince Kish for all of his lab knowledge and help setting up the test experiments. I would like to thank Suzanne Smith for her time helping me with the histology, polishing of bone, and answering questions on different chemicals used. I would like to thank Nina Clovis for her help in coordinating the materials for experiments. I would like to thank Sydha Salihu for answering questions that arose during the experimental process. I would like to thanks Matt Smith for his help during the experiment. Also thanks to anyone else whom I may not have mentioned. Lastly I would like to thank my family and friends for help and encouragement. 


\section{TABLE OF CONTENTS}

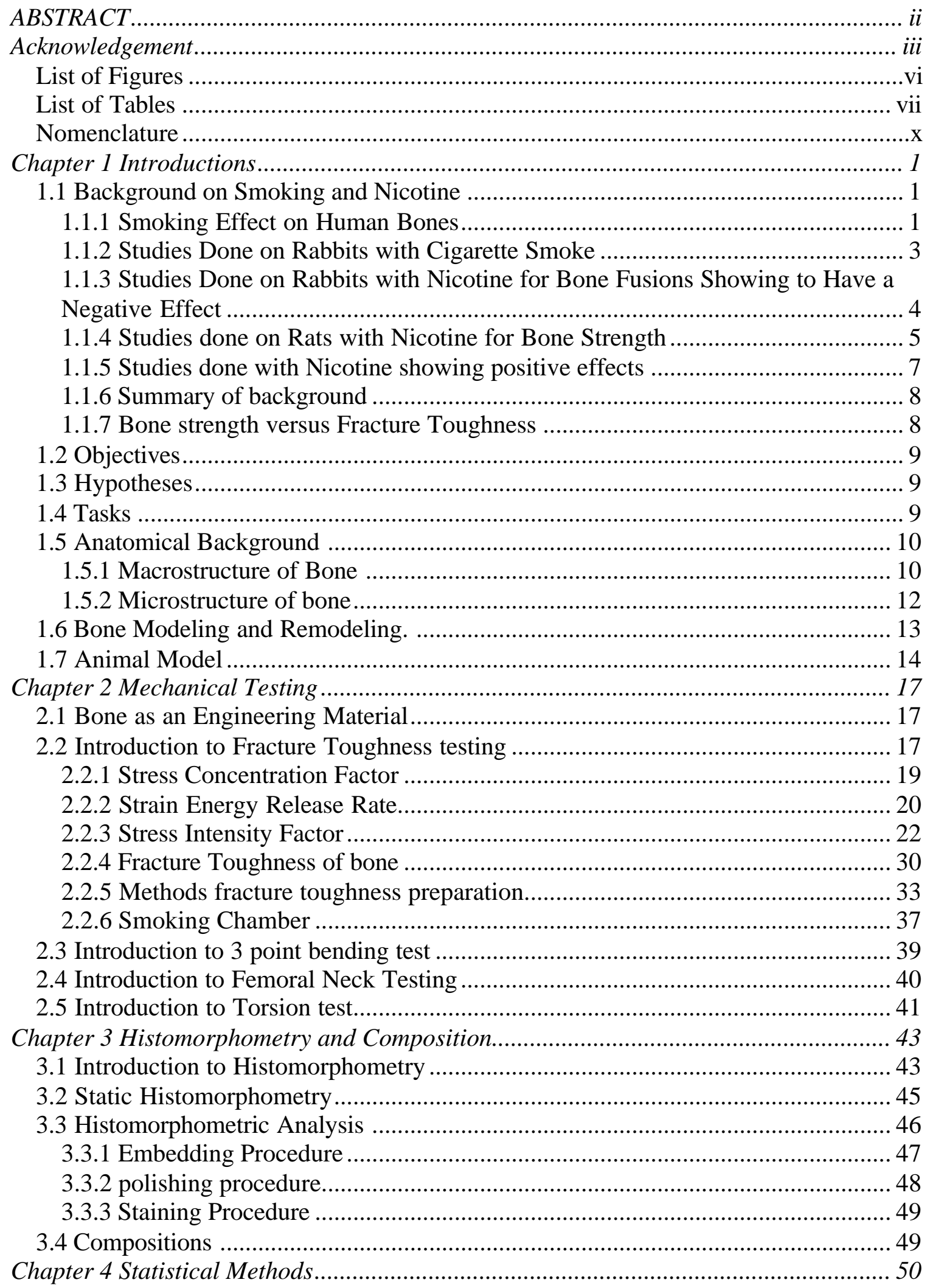




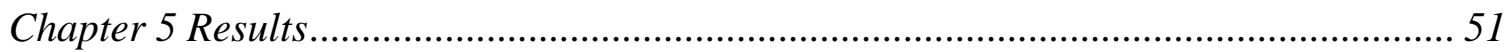

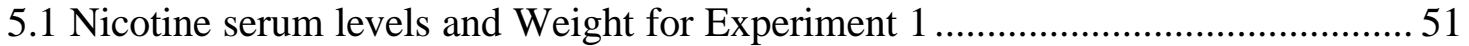

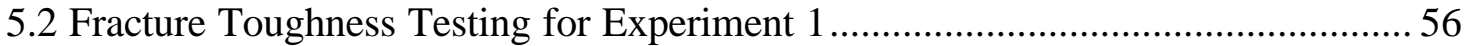

5.3 3-Point Bending Testing for Experiment 1 .................................................... 58

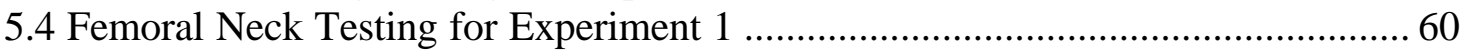

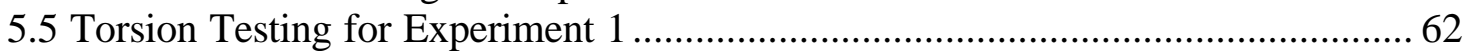

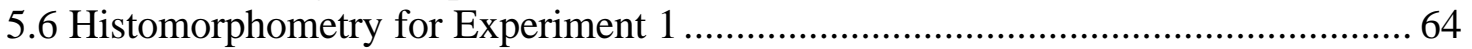

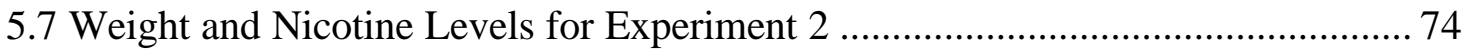

5.8 Fracture Toughness Values for Experiment 2 ................................................. 79

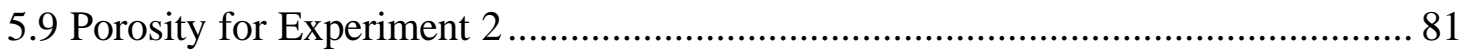

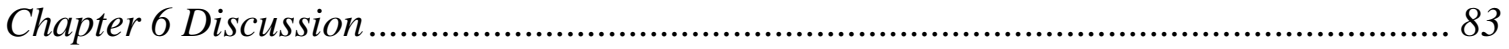

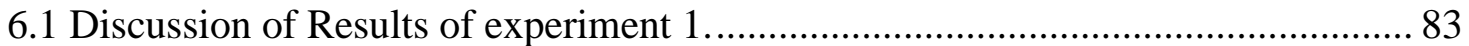

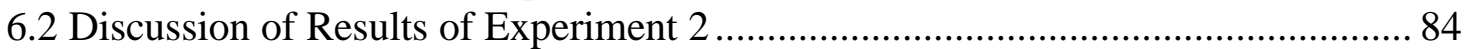

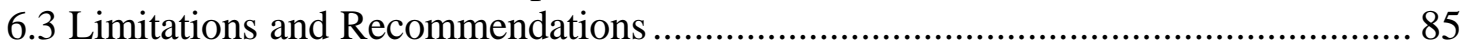

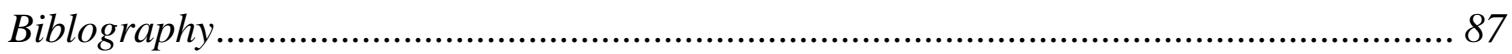

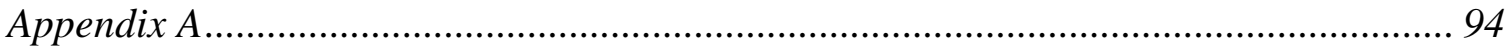

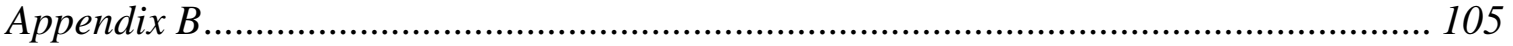




\section{List of Figures}

Figure 1.5.1 - 1: The Proximal Femur showing cortical and cancellous bone with labels added (Albright and Skinner 1987).

Figure 1.5.1 - 2: Coritcal and cancellous shown in more detail (Mow and Hayes 1991) 11

Figure 1.7 - 2: Definitions of locations and Anatomy of the Femur (Wingerd and Stein $1985)$

Figure 1.7 - 3: Definitions of locations and Anatomy of the Tibia (Wingerd and Stein 1985)

Figure $2.2-1$ : Crack growth in different type of materials (Anderson 1991) ................. 18

Figure 2.2.1 - 1: Elliptical hole in a flat plate (Anderson 1991) ................................... 19

Figure 2.2.2 -1: Cracked plate with a fixed load P (Anderson 1991) ............................ 22

Figure 2.2.3 - 1: Coordinate definition in front of the crack tip (Anderson 1991) .......... 23

Figure 2.2.3 - 2: Three different testing modes (Anderson 1991) ................................. 24

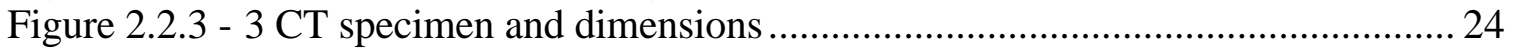

Figure 2.2.3 - 4: Regions for $\mathrm{K}_{\mathrm{IC}}$ of plain strain and stress (modification made)

(Anderson 1991) 26

Figure 2.2.3 - 5: Three different loads versus displacement curves for fracture toughness test with the 5\% secant line. (Anderson 1991) ..................................................... 28

Figure 2.2.3 - 6: Fracture toughness result with the 5\% secant line plotted ................... 29

Figure 2.2.3 - 7: ASTM notation for specimen obtained from a disks and hollow cylinders (Anderson 1991).

Figure 2.2.5 - 1: Dimensions of the fracture toughness specimen (Boresi and Schmidt

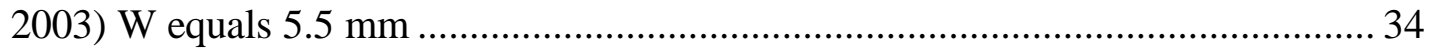

Figure 2.2.5 - 2: Location of the fracture toughness specimen on the tibia with adaptation

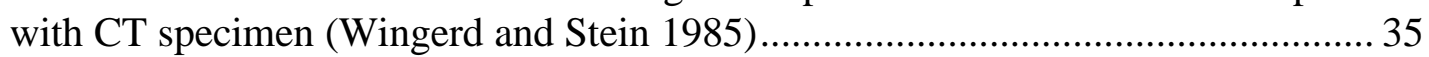

Figure 2.2.5 - 3: CT specimen made with dimension added (Vashishth 1991) ............... 36

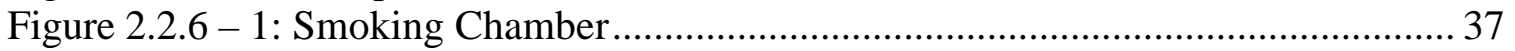

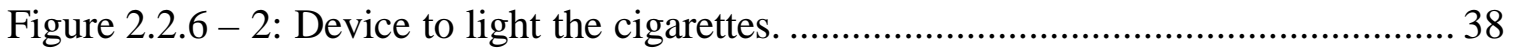

Figure $2.3-1$ : 3-point bending test set up (Akhter, Iwaniec et al. 2003) ........................ 39

Figure $2.3-2$ : Cross sectional area of the middle part of the tibia or femur (Engesaeter,

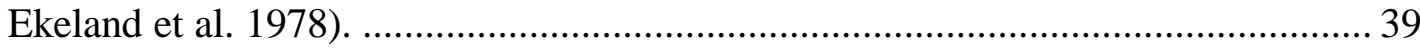

Figure $2.4-1$ : Location of where the load is applied for the femoral neck test (Smith

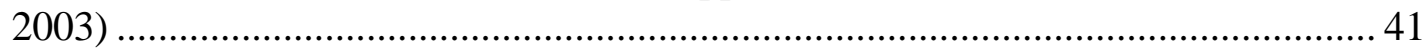

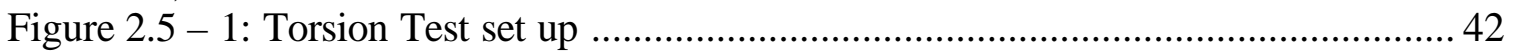

Figure 3.2 -1: Example Porosity Measurements (Wang 1995) .................................... 46

Figure $5.1-1$ : Average nicotine level for each group .............................................. 52

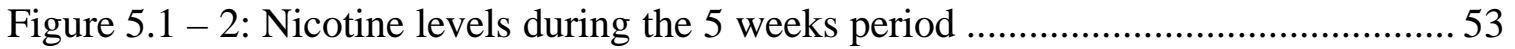

Figure 5.1 - 3: Average Weight of the rabbits during the 5-week period ....................... 54

Figure 5.1 - 4: Weight difference for each group ................................................... 55

Figure 5.1 - 5: Weight Difference for control and nicotine groups as a whole................ 55

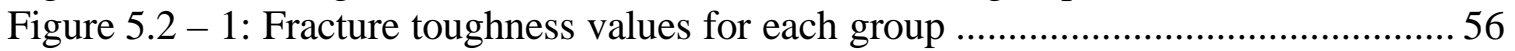

Figure 5.2 - 2: Fracture toughness of nicotine and control groups as a whole .................57

Figure $5.3-1$ : Average Bending Stress for each group .......................................... 58

Figure 5.3 -2: Bending Stress for Nicotine and control group as a whole .......................59

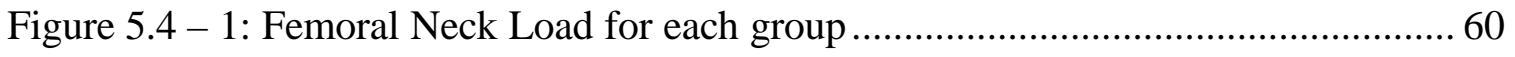




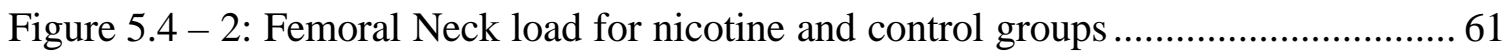

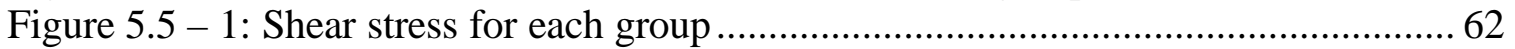

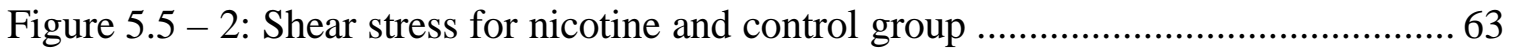

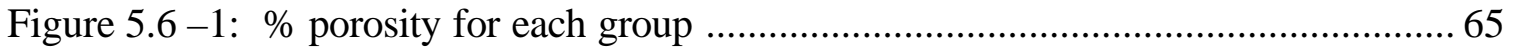

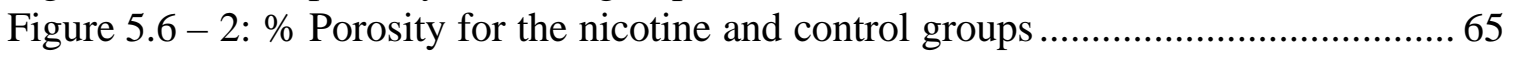

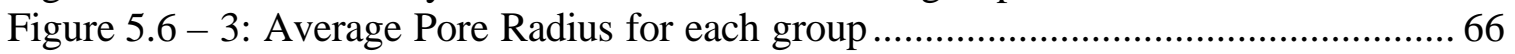

Figure 5.6 - 4: Average Pore Radius for the nicotine and control group ......................... 66

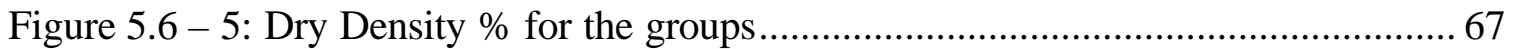

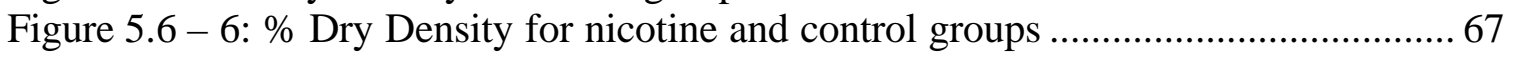

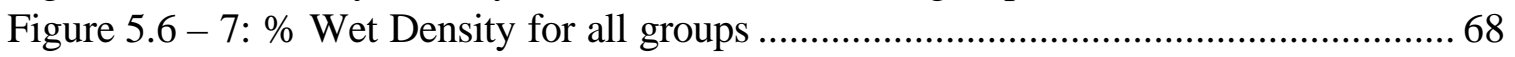

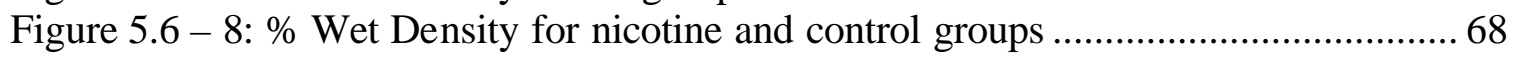

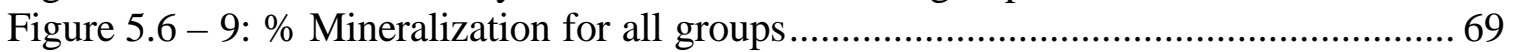

Figure 5.6-10: \% Mineralization for nicotine and control groups ................................69

Figure 5.6 - 11: \% Organic Wt. Dry for all groups ................................................... 70

Figure 5.6 - 12: \% Organic Dry for nicotine and control groups ................................. 70

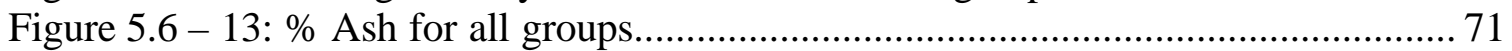

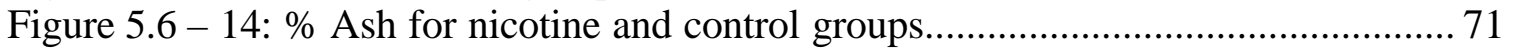

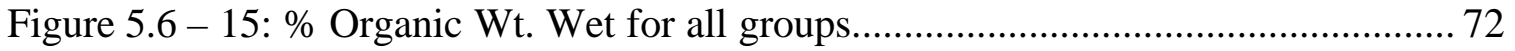

Figure 5.6 - 16: \% Organic Wt. Wet for nicotine and control groups............................ 72

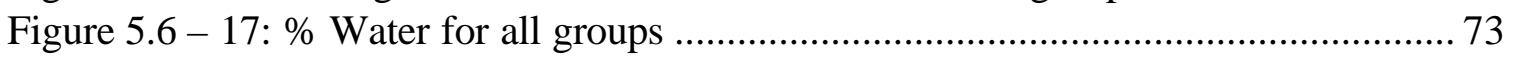

Figure 5.6 - 18: \% Water for nicotine and control groups ........................................ 73

Figure 5.7 - 1: Average nicotine level seen in each group during the 5 week period....... 75

Figure 5.7 - 2: Nicotine levels during the 5 weeks period ......................................... 76

Figure $5.7-3$ : Average Weight of the rabbits during the 5-week period ...................... 77

Figure $5.8-1$ : Fracture toughness values for each group ............................................ 79

Figure 5.9 - 1: Average $\%$ porosity for each group .................................................... 81

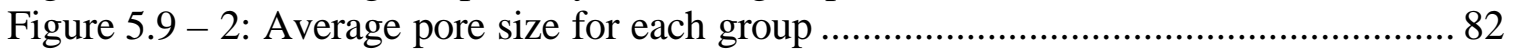

\section{List of Tables}

Table 2.2.4 - 1: Different variable effect on fracture toughness.

Table 2.2.4 - 2: Stress Concentration Factors for the Literature for the Tibia (Yeni 1998)

Table 5.1- 1: Values for figure 5.1-1 and $\mathrm{p}$ values for each group ................................52

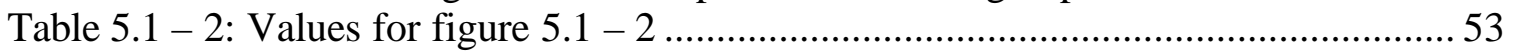

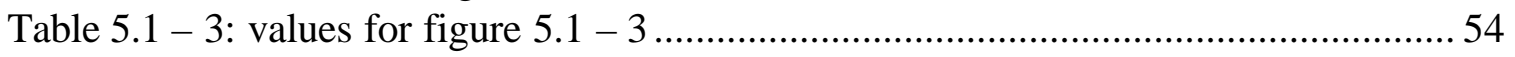

Table 5.1 - 4: Values for figures $5.1-4$ and $\mathrm{p}$ values for each group .......................... 55

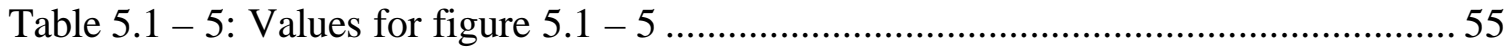

Table $5.2-1$ : Value for figure $5.2-1$ and $\mathrm{p}$ value for each group ................................56

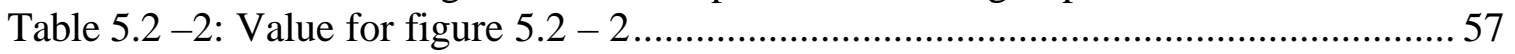

Table 5.2 - 3: Dimension for fracture toughness specimens groups ..............................57

Table 5.3-1: Values for figure 5.3 -1 and $p$ value for each group ...............................58

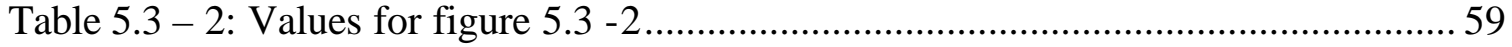

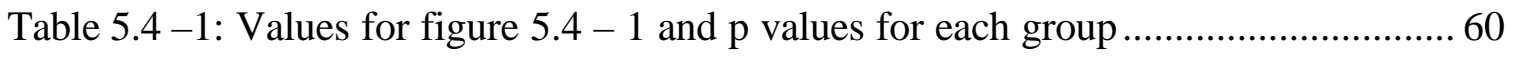

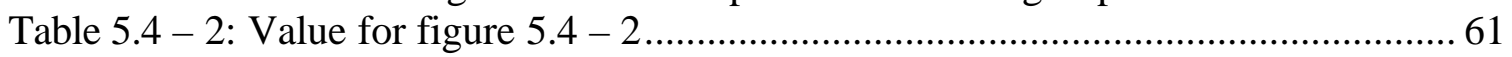

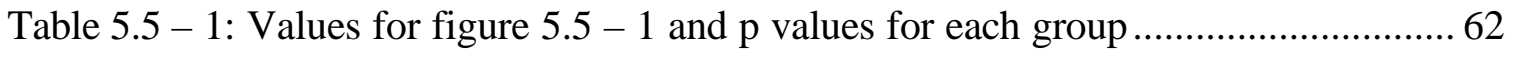


Table $5.5-2$ : Values for figure $5.5-2$ 63

Table 5.6 - 1: Values for figures 5.6 - 1 and $p$ values for each group .............................6 65

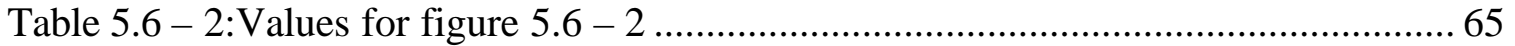

Table 5.6 - 3: Values for figures 5.6 - 3 and $p$ values for each group ........................... 66

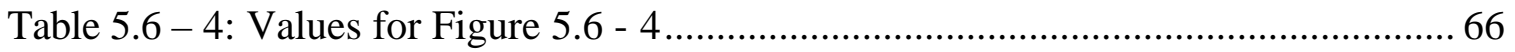

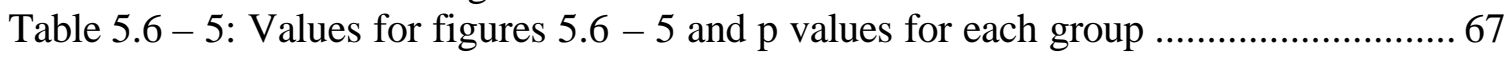

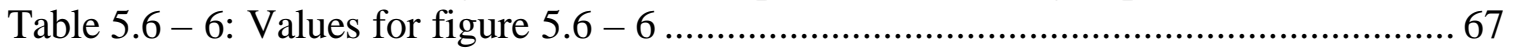

Table 5.6 - 7: Values for figures $5.6-7$ and $p$ values for each group ............................ 68

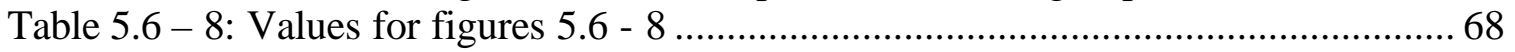

Table 5.6 - 9: Values for figures $5.6-9$ and $p$ values for each group ............................69

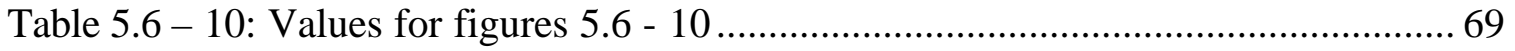

Table 5.6 - 11: Values for figures $5.6-11$ and $p$ values for each group ........................ 70

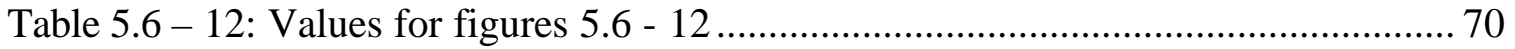

Table 5.6 - 13: Values for figures 5.6 - 13 and p values for each group ....................... 71

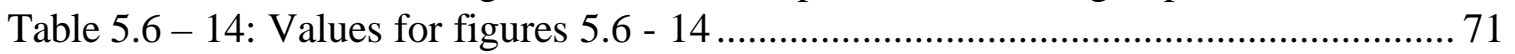

Table 5.6 - 15: Values for figures 5.6 - 15 and $\mathrm{p}$ values for each group ....................... 72

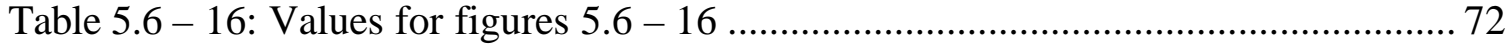

Table 5.6 - 17: Values for figures $5.6-17$ and $\mathrm{p}$ values for each group ....................... 73

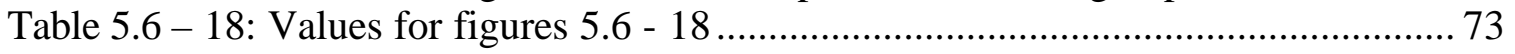

Table 5.7 - 1: Value for figure $5.7-1$ and $\mathrm{p}$ values for each group ............................ 75

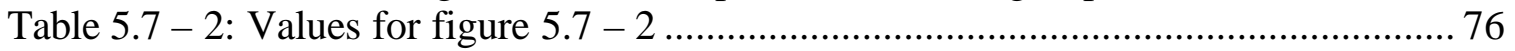

Table 5.7 - 3: Values for figure $5.7-3$ and $p$ values for each group ............................ 77

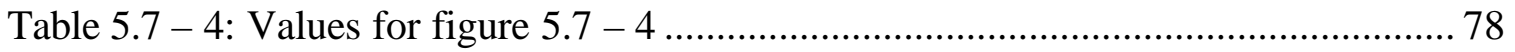

Table 5.8 -1: Values for figure 5.8 - 1 and $\mathrm{p}$ values for each group ............................. 79

Table 5.8 - 2: Dimension for fracture toughness specimen for each group ..................... 80

Table $5.9-1$ : Values for figure $5.9-1$ and $\mathrm{p}$ values for each group ............................ 81

Table 5.9 - 2: Values for figure $5.9-2$ and $\mathrm{p}$ values for each group ............................. 82

Table A1-a: Weight and Nicotine measurements for every Experiment 1 .................... 94

Table A1-b: Weight and Nicotine measurements for every rabbit in Experiment 1 .......95

Table A1-c: Weight and Nicotine measurements for every rabbit in Experiment 1 ...... 95

Table A2-a: Fracture toughness measurement and values for each rabbit in Experiment 1

96

Table A2-b: Fracture toughness measurement and values for each rabbit in Experiment 1

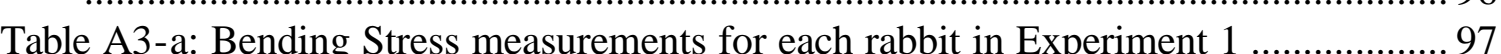

Table A3-b: Bending Stress measurements for each rabbit in Experiment 1 ................. 97

Table A3-c: Bending Stress measurements for each rabbit in Experiment 1 .................98

Table A4-a: Femoral Neck Load for each measurement in Experiment 1 ......................98

Table A5-a: Shear Stress Measurements for each rabbit in Experiment 1 ..................... 99

Table A5-b: Shear Stress Measurements for each rabbit in Experiment 1 ..................... 99

Table A5-c: Shear Stress Measurements for each rabbit in Experiment 1 .................... 100

Table A6-a: Volume 1 Measurements for each rabbit in Experiment 1 ........................ 100

Table A6-b: Volume 2 Measurements and Average Measurement for each rabbit in

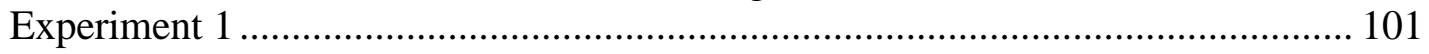

Table A6-c: Wet Wt. Measurements for each rabbit in Experiment 1 .......................... 101

Table A6-d: Defatted Wt. Measurements for each rabbit in Experiment 1 .................. 102 
Table A6-e: Dry Wt. 1 \& 2 Measurements for each rabbit in Experiment 1................ 102

Table A6-f: Ash Wt. Measurements for each rabbit in Experiment 1 ......................... 103

Table A6-g: Composition. Measurements for each rabbit in Experiment 1 ................. 103

Table A7-a: Porosity and radius size measurement for each rabbit in Experiment 1 .... 104

Table B1-a: Weight and Nicotine measurements for every rabbit in Experiment 2..... 105

Table B1-b: Weight and Nicotine measurements for every rabbit in Experiment 2 ..... 106

Table B1-c: Weight and Nicotine measurements for every rabbit in Experiment 2...... 107

Table B2-a: Fracture toughness measurement and values for each rabbit in Experiment 2

Table B2-b: Fracture toughness measurement and values for each rabbit in Experiment 2

Table B3-a: Porosity for Experiment 2 


\section{Nomenclature}

General:

ASTM: American Society of Testing Mechanics

a: $\quad$ major axis

a: $\quad$ crack length

A: $\quad$ Crack Area

AW: $\quad$ Ash Weight

AvPoRd: Average Pore Radius

b: $\quad$ minor axis

B: $\quad$ Thickness

BMU: $\quad$ Bone Multicelluar Unit

BMD: $\quad$ Bone Mineral Density

BMC: $\quad$ Bone Mineral Content

C: Control

C: $\quad$ dimensionless constant that depends on geometry and mode of

loading

$\mathrm{C}$ : compliance

CDC: $\quad$ Center of Disease Control

${ }^{\circ} \mathrm{C}$ : Celsius

CT: $\quad$ Compact Tension

DW: $\quad$ Dry Weight

EPFM Elastic plastic fracture mechanics

F: $\quad$ work done by external force

Fx: $\quad$ Fracture

Fem: $\quad$ Fem(ur)(oral)

$\mathrm{F}$ : work done by external force

$\mathrm{f}_{\mathrm{ij}}$ : dimensionless function

$\mathrm{f}(\mathrm{a} / \mathrm{W})$ : dimensionless function

g: $\quad$ gram

G: $\quad$ Strain energy release rate

$\mathrm{G}_{\mathrm{C}}$ : $\quad$ Critical Strain energy release rate

Hn.Cn.Ar: Haversian Canal Area

$\mathrm{K}$ : $\quad$ stress intensity factor

$\mathrm{K}_{\mathrm{C}}$ : $\quad$ Critical stress intensity factor

$\mathrm{K}_{\mathrm{I}}$ : $\quad$ Mode 1 opening

$\mathrm{K}_{\mathrm{II}}$ : $\quad$ Mode 2 sliding

$\mathrm{K}_{\mathrm{III}}$ : $\quad$ Mode 3 tearing

kg: $\quad$ Kilogram

IP: moment of polar inertia

I: moment of inertia

LEFM: $\quad$ Liner elastic fracture mechanics

M: $\quad$ Moment

MMA: methymethacrlate

min: $\quad$ Minute

ml: $\quad$ Milliliter 


\begin{tabular}{|c|c|}
\hline $\mathrm{mm}:$ & millimeters \\
\hline mg: & Milligram \\
\hline $\mathrm{N}:$ & Nicotine \\
\hline ng: & NanoGram \\
\hline n: & number \\
\hline OVX: & Ovariectomized \\
\hline P: & load \\
\hline pa: & pascal \\
\hline $\mathrm{P}_{\mathrm{Q}}:$ & Critical Load \\
\hline Pr.Po.Ar: & Primary Pore Area \\
\hline Po: & Porosity \\
\hline PTH: & parathyroid hormone \\
\hline psi: & pound per square inch \\
\hline rpm: & rotation per minute \\
\hline r: & radius \\
\hline s: & Second \\
\hline Sham: & Surgery was done but nothing extra was added to the surgery \\
\hline $\mathrm{T}:$ & Torque \\
\hline $\mathrm{t}:$ & thickness \\
\hline TrAr: & Total Bone Area \\
\hline V.Cn.Ar: & Volksmann Canal Area \\
\hline $\mathrm{U}:$ & Strain energy \\
\hline $\mathrm{V}:$ & Volume \\
\hline W: & length from center of drilled hole to the end of the CT specimen \\
\hline see figure & $5-1$ \\
\hline WW: & Wet Weight \\
\hline ?s: & energy to break a bond \\
\hline ?p: & plastic work \\
\hline $\mathrm{t}:$ & shear stress \\
\hline$?:$ & radius of curvature \\
\hline$?:$ & potential energy \\
\hline $\mathrm{U}:$ & strain energy stored in the body \\
\hline$?:$ & displacement \\
\hline$\mu g:$ & Microgram \\
\hline$\sigma:$ & Stress (pa) \\
\hline$\sigma_{\mathrm{A}}:$ & Stress at point $\mathrm{A}$ \\
\hline $\mathrm{S}_{\mathrm{ij}}:$ & stress tensor \\
\hline $\mathrm{S}_{\text {nom: }}$ & Stress nominal \\
\hline $\begin{array}{l}\text { S ys: } \\
\text { ?. }\end{array}$ & $\begin{array}{l}\text { Yield Stress } \\
\text { angle }\end{array}$ \\
\hline
\end{tabular}




\section{Chapter 1 Introductions}

\subsection{Background on Smoking and Nicotine}

About 50 million of the United States adult population smokes. Some risks due to smoking for bone include the increased risk of osteoporosis; increase injuries and stress fractures during basic training, and lower fusion rates of bone healing. According to the CDC postmenopausal women who currently smoke have lower bone density than do women who do not smoke. Also women who currently smoke have an increased risk for hip fracture compared with nonsmoking women. A cigarette has over 4,000 chemicals contained in it. Nicotine is the most well known of these chemicals, however cigarettes have 60 known carcinogens. Nicotine is the agent that causes the addiction to the cigarette. The average smoker takes in 1 to $2 \mathrm{mg}$ of nicotine per cigarette. Nicotine can act as both a stimulant and sedative. Many clinical studies have looked at the effect of smoking on bone.

\subsubsection{Smoking Effect on Human Bones}

In clinical studies done on the effect of smoking on human bones found that smoking has a negative effect on bone mineral density, and that the cessation of smoking can help recover from the negatives effect of smoking but not completely. Most patients who showed symptoms of osteoporosis before the age of 65 were smokers (Daniell 1972). Gerdhem has found that smoking has negative effect on bone mass independent of difference in weight, but no differences in bone mass were found between former smokers and non-smokers (Gerdhem and Obrant 2002). Daniell, in another study, found results similar to Gerdhem in that smoking has negative effect on bone mass independent 
of weight for younger women 40-49, but in older women age 60-69 he found that weight also had an effect on bone mass in that non-obese women had less bone mass than obese women (Daniell 1976). Cornuz and Baron also found that smoking cessation reduces the risk of hip fractures (Cornuz, Feskanich et al. 1999; Baron, Farahmand et al. 2001).

Ortego-Centeno (Ortego-Centeno, Munoz-Torres et al. 1997) found that smoking by healthy young males is associated with decreased bone mass. Heavy smokers (greater than 20 cigarettes per day) had lower BMD in all skeletal sites compared to nonsmokers. In meta-analysis done by Ward (Ward and Klesges 2001), studies show smoking increased the risk of vertebral fracture by $13 \%$ in woman, and $32 \%$ in men; and hip fracture by $31 \%$ in woman, and $40 \%$ in men, however the cessation of smoking partially reverses these risks. In another meta-analysis done by Law (Law and Hackshaw 1997), studies found that smoking has no effect on premenopausal women, but postmenopausal women have $.2 \%$ increase of bone mass loss per year due to smoking. One out of eight hip fractures in women are attributable to smoking. In former smokers these effects of bone density and risk fracture were less than current smokers but more than people who never smoked.

Smoking has also been shown to increase the risk of injury and stress fractures. In the army, many injuries happen during basic training. People who smoke 1-10 cigarettes per day have increased risk of injury, while those who smoke more than 10 cigarettes per day have a higher chance of injury compared to those who do not smoke during basic training(Reynolds, Heckel et al. 1994). Lappe (Lappe, Stegman et al. 2001) and Friedl (Friedl, Nuovo et al. 1992) found that female army recruits that had developed stress fractures were more likely to report current smoking or past smoking habits. 
Of 160 patients with hind foot fusions, smokers had a higher rate of non- unions than did non-smokers (18.6\% to 7.1\%) (Ishikawa, Murphy et al. 2002) (Ishikawa 2002). The rate of non- unions for former smokers was lower than current smokers, but higher than people who never smoked.

\subsubsection{Studies Done on Rabbits with Cigarette Smoke}

Studies were done by Ueng (Ueng, Lin et al. 1999) on rabbit tibia to see if cigarette smoke had an effect on bone mineral density (BMD) and torsional strength. The cigarette smoke was delivered via a smoking chamber for 7 minutes every 30mins for 8 hours a day. An operation was done to lengthen the rabbits' right tibia by $5 \mathrm{~mm}$. Ueng found that BMD of the smoke inhalation group was significantly lower than the control group at 4, 5, and 6 weeks after the operation. Ueng also found that the torsion strength in the smoking group was significantly lower than the control group. Ueng (Ueng, Lee et al. 1997) performed another study which found that torsion strength in healing rabbit tibia was lower for the smoking group at 4 weeks $(\mathrm{P}<.01), 6$ weeks $(\mathrm{p}<.01)$ and 8 weeks $(\mathrm{p}<.05)$. A histology study was done which found that new bone formations were higher in the non-smoking inhalation rabbits than those in the smoke inhalation group. These results suggest that smoking delays minerization during the bone healing process. These studies thus far, show that smoking has an impact on bone mass, increased risk to fractures, and delayed bone fusions, however they do not tell which chemicals contained in cigarettes may be responsible for this impact. 


\subsubsection{Studies Done on Rabbits with Nicotine for Bone Fusions Showing to Have a Negative Effect}

All of the studies listed in this section had nicotine delivered via ostmotic minipumps. Many studies have been done to show the effect of nicotine on fusion rates. Silcox (Silcox, Daftari et al. 1995) used New Zealand White rabbits for spinal fusions and found that the nicotine group had a lower fusion rate than the control group. The average nicotine serum levels for the nicotine group was $88.8 \mathrm{ng} / \mathrm{ml}$, and the median was $74.1 \mathrm{ng} / \mathrm{ml}$. The rabbits' weights did not change over time for either group.

In 1998, another study done by Silcox found the effects of nicotine can be overcome with an osteoinductive bone growth factor in an animal model (Silcox, Boden et al. 1998). A dosage of $4.5 / \mu \mathrm{g} / \mathrm{kg} / \mathrm{minute}$ was used to achieve a dosage of 10-70 ng.ml of nicotine serum level, which is the same as smoking 20 to 30 cigarettes a day.

Daftari (Daftari, Whitesides et al. 1994) found that nicotine inhibits, but does not prevent, the revascularation of cancellous bone grafts. For Daftari study a dosage of 6 $\mathrm{ug} / \mathrm{kg} / \mathrm{min}$ was used to achieve the dosage of $10-70 \mathrm{ng} / \mathrm{ml}$. Also no difference in weight was seen between the two groups after 4 weeks. Riebel (Riebel, Boden et al. 1995), did another study that also showed similar results as Daftari.

Raikin (Raikin, Landsman et al. 1998) found in long bone fracture healing that the nicotine group had a $17.2 \%$ lower in callus formation between the control groups, and an increase in non unions in the nicotine group. A 3-point bending test showed the nicotine group to be $26 \%$ weaker than control group. The dose given to the rabbit was 6.0

$\mathrm{ng} / \mathrm{kg} / \mathrm{minute}$. The nicotine serum level average for the 8 weeks was $61 \mathrm{ng} / \mathrm{ml}$. The 
nicotine rabbit in this group gained less weight then the control group but it was not significant at $\mathrm{p}=.065$.

Wing (Wing, Fisher et al. 2000), showed that rabbits exposed to nicotine but had been weaned prior to fusion had higher fusion rates than those who had not been weaned, but lower than those who had not been exposed to nicotine. The biomechanical properties between the groups had no significant differences. The nicotine serum level seen during the study was $32 \mathrm{ng} / \mathrm{ml}$.

\subsubsection{Studies done on Rats with Nicotine for Bone Strength}

A number of studies have been done to see if nicotine is the main agent for causing weakened bone strength by using rats that are subjected to different nicotine doses in healthy bone. It has been shown in rats that nicotine has little or no effect on bone strength, no matter the amount of time, the way the nicotine was distributed, age of the rat, or if the rats were ovariectomized or not.

Fung's (Fung, Mendlik et al. 1998; Fung, Iwaniec et al. 1999) study showed that was no differences were found in histomorphomertic end-points, bone mineral density, bone mineral content and vertebral strength of 7-month-old rats. Fung did find a decrease of the serum 25-hydroxyvitamin D by $30 \%$ for a $2 \& 3$ months period. The nicotine was delivered via ostmotic minipumps for both the 2 and 3 months study. For the 2-month study the average nicotine serum level was $33.1 \mathrm{ng} / \mathrm{ml}$ for the $3.0 \mathrm{mg} / \mathrm{kg} /$ day group and $55.6 \mathrm{ng} / \mathrm{ml}$ for the $4.5 \mathrm{mg} / \mathrm{kg} /$ day group. The average nicotine serum levels for

the 3 month study was 60 for the $3 \mathrm{mg} / \mathrm{kg} /$ day and 85 for the $4.5 \mathrm{mg} / \mathrm{kg} / \mathrm{day}$. No significant difference was found in the body weights for the 2 or 3 months studies. 
Syversen (Syversen, Nordsletten et al. 1999) used a chamber with nicotine vapor to expose 2-month-old growing rats to nicotine and found no significant difference in ultimate bending moment, ultimate energy absorption, stiffness, or deflection between the two groups. There was no difference found in BMD between control rats or the nicotine exposed rats. This study found that rats exposed to nicotine weigh approximately $10 \%$ less then the controls.

Iwaniec (Iwaniec, Fung et al. 2000; Iwaniec, Fung et al. 2001) did a study using 7 month old rats giving them various doses of nicotine for 2 or 3 months and found that the turnover rates in cancellous or cortical tibial bone, femoral density, and bone mineral content did not change when subjected to varying nicotine doses. There was a lower femoral ultimate load and vertebral bone mineral content (BMC) in high dose nicotine group $(6.0 \mathrm{mg} / \mathrm{kg} / \mathrm{day})$ than in control rats. Not difference was detected in $25-$ hydroxyvitiamin D serum levels. Iwaniec concluded that nicotine serum level, 2.5 times greater than the average smoker had limited effects on bone. The nicotine serum level for this study is 111 for the $4.5 \mathrm{mg} / \mathrm{kg} / \mathrm{day}$ and 137 for the $6.0 \mathrm{mg} / \mathrm{kg} / \mathrm{day}$. This study also found that rats that received nicotine weighed approximately $7 \%$ less than the controls, but did not lost any weight.

Iwaniec (Iwaniec, Fung et al. 2000)in another study was looking at the effect of serum mineral and calciotropic hmormones levels, bone resorption, bone mass, and bone strength. No difference was detected in the serum mineral levels or hormone concentration for all groups. Also no differences were found in BMD, BMC or bone strength. They concluded that no difference were detect for 2 or 3 months in a growing 
rat. The body weights for each group went up over time but no difference were detected. The nicotine serum level for the 3.0 and $4.5 \mathrm{mg} / \mathrm{kg} / \mathrm{day}$ was 67 and $89 \mathrm{ng} / \mathrm{ml}$.

Akhter (Akhter, Iwaniec et al. 2003) did a study to see if nicotine affected ovariectiomized rats 8 months in age. What he found was that nicotine had no effect on BMC, BMD, or any of the structural and material strength properties in either the OVX or Sham.

\subsubsection{Studies done with Nicotine showing positive effects}

A study done by Waldum (Waldum, Nilsen et al. 1996) on the long term effect of nicotine, over 2 years, on rats showed that nicotine did not increase mortality, atherosclerorsis, or amount of tumors compared to controls. Heeschen (Heeschen, Jang et al. 2001) has shown that nicotine stimulated angiogenesis both in vitro and in vivoin animal models not involving bone.

Two studies done by France and Norman (France and Norman 2002) found the nicotine groups had higher fusions rates than control groups for rabbits. The nicotine in these studies was delivered via nicotine patch. In another study done by (France and Norman 2003) it was found that a nicotine patch of $5.25 \mathrm{mg} /$ day has a higher fusion rate then the other nicotine groups and control, however this rate was non significant. Also the biomechanical testing and radiographic evaluations showed similar results. The serum level for the $5.25 \mathrm{ng}$ patch is $7.8 \mathrm{ng} / \mathrm{ml}$. The daily average serum level for heavy smokers (10-70 ng/ml) (Benowitz and Jacob 1984; Daftari, Whitesides et al. 1994; Sipe, Buck et al. 2000). An another study done by Mukherjee (Mukherjee, France et al. 2003)found that in rabbit bone marrow derived large dose of nicotine $100 \mu \mathrm{g} / \mathrm{ml}$ significantly increases osteoblastic activity over controls. 


\subsubsection{Summary of background}

Studies in humans suggest that smoking cigarettes increases your risk for osteoprorois, stress fractures and reduces bone healing, however the cession of smoking shows a decrease in these risks. Many studies in rabbits have been done on nicotine effects on bone healing and bone strength. From the studies done with nicotine on bone strength it is shown that nicotine does not have an effect on bone strength. It is debatable if nicotine has any effect on bone healing. Most of the studies show that nicotine has a negative effect on bone healing but recent studies done by France, Norman, and Mukherjee have shown nicotine to help bone healing. In these studies the nicotine was administer via nicotine patches and the increase of osteoblastic activities, which may explain why the nicotine groups having better or equal fusion rates compared to controls.

\subsubsection{Bone strength versus Fracture Toughness}

Bone is a flawed material microscopically and usually under goes a series of loading and unloading. Another way to measurement bone quality is fracture toughness, which is the mechanical property ability to resist crack initiation and growth (Norman 1991). According to Anderson, Zipoupos and Curry (Anderson 1991; Zioupos and Currey 1998) bone strength and fracture toughness cannot be predicted from one another. To the best of my knowledge and research no one has studied the effects of nicotine and smoking on fracture toughness of bone. 


\subsection{Objectives}

The objective of this research is to study the dose dependent effect of nicotine delivered via patch and from cigarette smoke on bone's mechanical properties. The effect of nicotine and smoking on bone histology will also be investigated.

\subsection{Hypotheses}

1. Nicotine has a non-debilitating effect on bone mechanical properties where as, smoking does have a debilitating effect on bone mechanical properties.

2. The effects of nicotine and smoking on bone fracture toughness and strength can be explained by changes in bones' histomorphomety and composition.

\subsection{Tasks}

Using bone taken from rabbits exposed to nicotine via a transdermal patch and cigarette smoke, the following tasks will be performed. Two experiments were done. The first experiment compared different nicotine patch, and the second experiment compared nicotine delivered via a patch and smoke inhalation.

Task 1: Biomechanical testing including fracture toughness, femoral neck loading, 3point bending test, and torsion test for experiment 1 and fracture toughness test for experiment 2 .

Task 2: Histomophometric and compositional analysis of cortical bone from the tibia for experiment 1 and histomophometric for experiment 2.

Task 3: Statistical analysis comparing mechanical and histological properties in each test group. 


\subsection{Anatomical Background}

In this section bone biological properties will be discussed. There are four main functions of bone. The first two are mechanical support and protection of vital structures, but bone is also responsible for Hematopoiesis, which is the production of red blood cells, and Mineral Homeostasis, which is the bodies' primary place to store calcium. Bone is a living organ, which has the ability to adjust to new loads and repair itself after damage by constantly removing and restoring bone through resorption of old bone and formation of new bone.

\subsubsection{Macrostructure of Bone}

Macrostructure of bone is made up of two main type of bone, cancellous and cortical bone. Cancellous bone is found at the ends of most long bones and in short bone it fills most of the bone, an example of short bone is the spine. Cancellous bone or trabeculear bone is spongy bone with many cavities surrounded by cortical bone as shown in figure 1.5.1 - 1. Cortical bone or compact bone is very dense, is mainly bone matrix with canals, which are called haversian canals as shown in figure 1.5.1 - 2. 


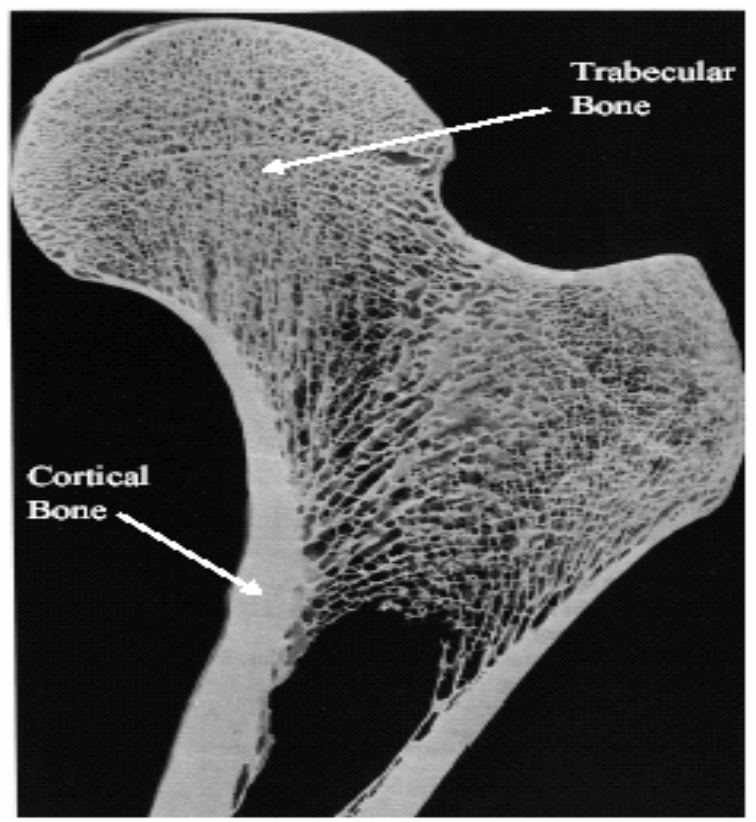

Figure 1.5.1 - 1: The Proximal Femur showing cortical and cancellous bone with labels added (Albright and Skinner 1987)

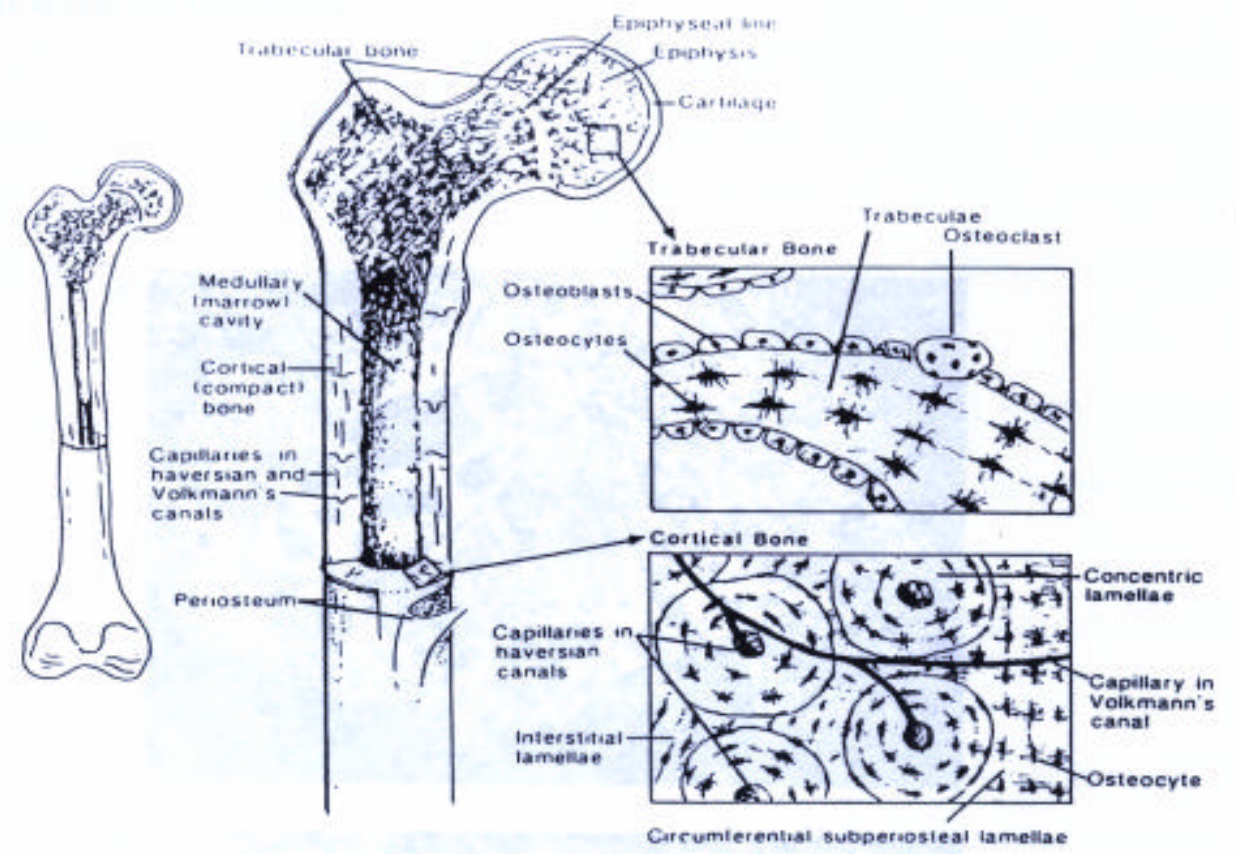

Figure 1.5.1 - 2: Coritcal and cancellous shown in more detail (Mow and Hayes 1991) 


\subsubsection{Microstructure of bone}

Mature bone matrix is normally made up of about $35 \%$ organic and $65 \%$ inorganic materials. Of the organic material about $90 \%$ of it is type 1 collagen. Collagen gives the bone its flexibility, and strength in tension. The $65 \%$ of the inorganic material is called hydroxyapatite, which has the molecular formula $3 \mathrm{Ca}\left(\mathrm{PO}_{4}\right) \bullet \mathrm{Ca}(\mathrm{OH})_{2}$. This mineral gives the matrix toughness in compressive strength and stiffness.

Microstructure of bone also is made up of 2 main types of bone, lamellar and woven bone. According to Burr and Martin, woven bone is bone that is irregular in formation, and unorganized pattern of collagen orientation (Martin and Burr 1989). Woven bone can be placed down de novo without any hard tissue already there to support it. No other type of bone can be formed de novo. In adults woven bone is usually found after a pathologic skeletal process. Main function of woven bone is for skeletal repair and defense. The most common example of woven bone in adults is callus found in bone fractures (Burr and Martin 1989).

Primary lamellar bone requires a surface to be deposited upon, unlike woven, which does not. Primary lamellar is found in both cancellous and cortical bone. This bone collagen orientation is arranged in a circular pattern around the inner (endosteal) and outer (periosteal) circumference of whole bone. This primary lamellar bone can be very dense. Primary lamellar bone is bone found in the first generation of bone, before bone undergoes remodeling. When the bone is the product of bone resorption or remodeling it is called secondary lamellar bone. 


\subsection{Bone Modeling and Remodeling.}

Secondary lamellar bone comes from remodeling of bone by Basic Multicellur Unit (BMU). First, a signal is needed to begin bone remodeling. According to Albright and Skinner, this is done by the parathyroid hormone $(\mathrm{PTH})$, which is emitted from the parathyroid gland (Albright and Skinner 1987). When blood calcium levels get too low the secretion of PTH happens. This stimulates osteoclast (see figure 1.5.2 - 2) activity. Osteoclast is a cell that is responsible for removing or absorption of bone. After the osteoclast is done there is lag time between removal and new formation of bone. Because of the lag time and reversal in formation a cement line forms. According to Wang cement lines are less stiff than bone, which allow them to arrest crack propagation (Burr, Schaffler et al. 1988; Wang 1995). After a short period of time bone formation begins by osteoblast (see figure 1.5.2 - 2). Osteoblasts are much smaller than osteoclasts, and do not refill the canal completely. Once an osteoblast is surrounded by bone matrix it becomes an osteocyte (see figure 1.5.1 - 2). Osteocytes are thought to be signaling cells in bone, and detect mechanical stimulation. The remaining osteoblast become cell lining for the haverisan canal. The haversian canal is surround by the secondary bone that is lamellar in nature. The entire secondary osteon is about 200 to $300 \mu \mathrm{m}$ in diameter. Cells seen around the center of the haversian canal are osteocytes and are in circular patten to ensure maximum supply of nutrients to more bone tissue.

The resoprtion and formation of normal bone is usually in balance. Both cortical and cancellous bone under-goes remodeling. Bone remodeling starts at about the seventh week of embryonic life continuing till death. Bone undergoes remodeling to repair damaged bone and to adjust the bone structure for new load supports. This balance is 
important if there is too much remodeling then the bone becomes too porosis, if there is not enough remodeling then cracks can grow causing factures. When osteoclast become more active and osteoblast become less active or stays the same, the skeletal mass decreases thus increasing the risk for fractures.

\subsection{Animal Model}

These studies will utilize bone from a different study that investigated the effect of nicotine and cigarette smoke on spine fusion. The first group will be a study comparing the effect of different nicotine doses via patch on bone. The second test group will be the nicotine given via patches versus inhaled cigarette smoke. In this study the nicotine was administrated though a nicotine patch, (Habitrol, Parsippary, NJ) and via a chamber containing cigarette smoke. The type of cigarette used in this study was Marlboro (Phillip Morris, Richmond, VA). It has been shown that nicotine levels are higher with nicotine delivered by a patch and the concentration of nicotine stays in the blood longer (Sipe, Buck et al. 2000). The rabbits that were used are New Zealand White rabbits, which are male retired breeders, and are skeletally mature. The rabbit's age is about 24 to 29 months. These rabbits were obtained from Covance (Denver, PA).

Figure $1.7-1$ shows the rabbit skeleton. The bones used in this study were the femur, and tibia. All the bones were retrieved during dissection. Figures $1.7-2$ and $1.7-3$ show the anatomy for the femur and tibia. The proximal end is the end of the bone closest to the midpoint of the body. The mid-shaft is in the middle bone between the proximal end and the distal end. The distal end is the part of the bone closest to the ventral side or in this case near bottom. 


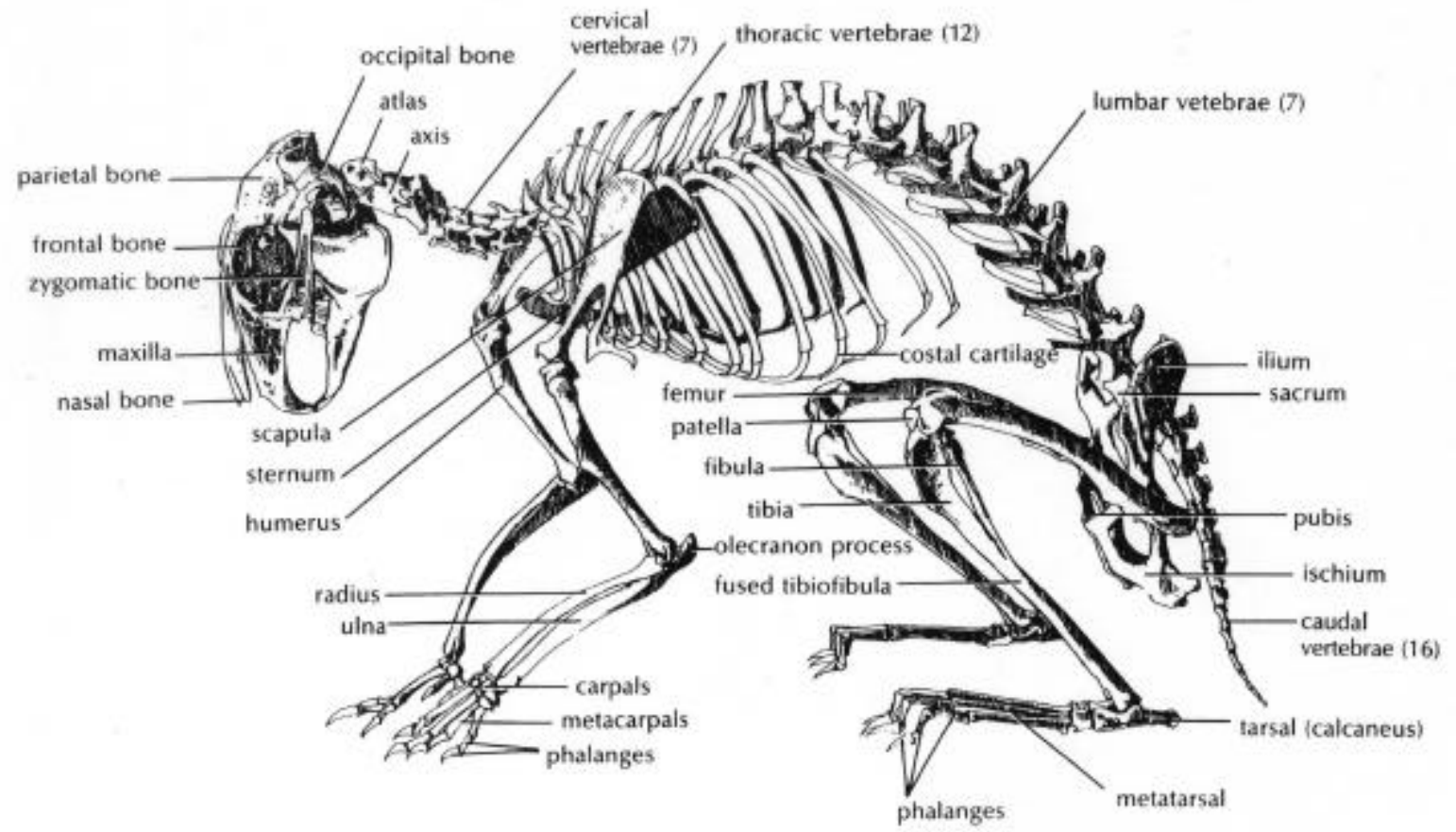

Figure 1.7 - 1: Diagram of rabbit skeleton (Wingerd and Stein 1985)

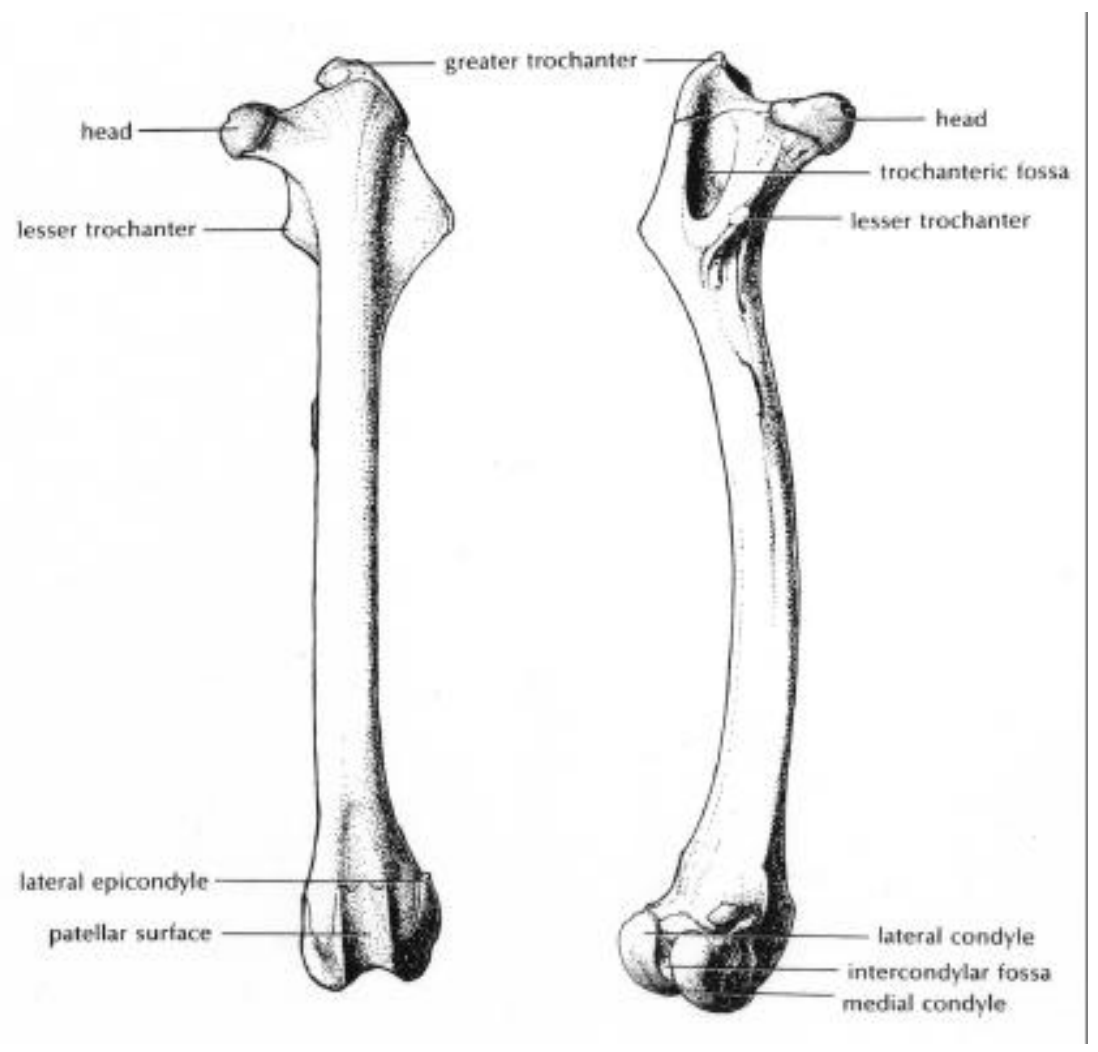

Proximal

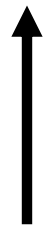

Mid-shaft

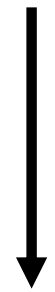

Distal

Figure 1.7 - 2: Definitions of locations and Anatomy of the Femur (Wingerd and Stein 1985) 


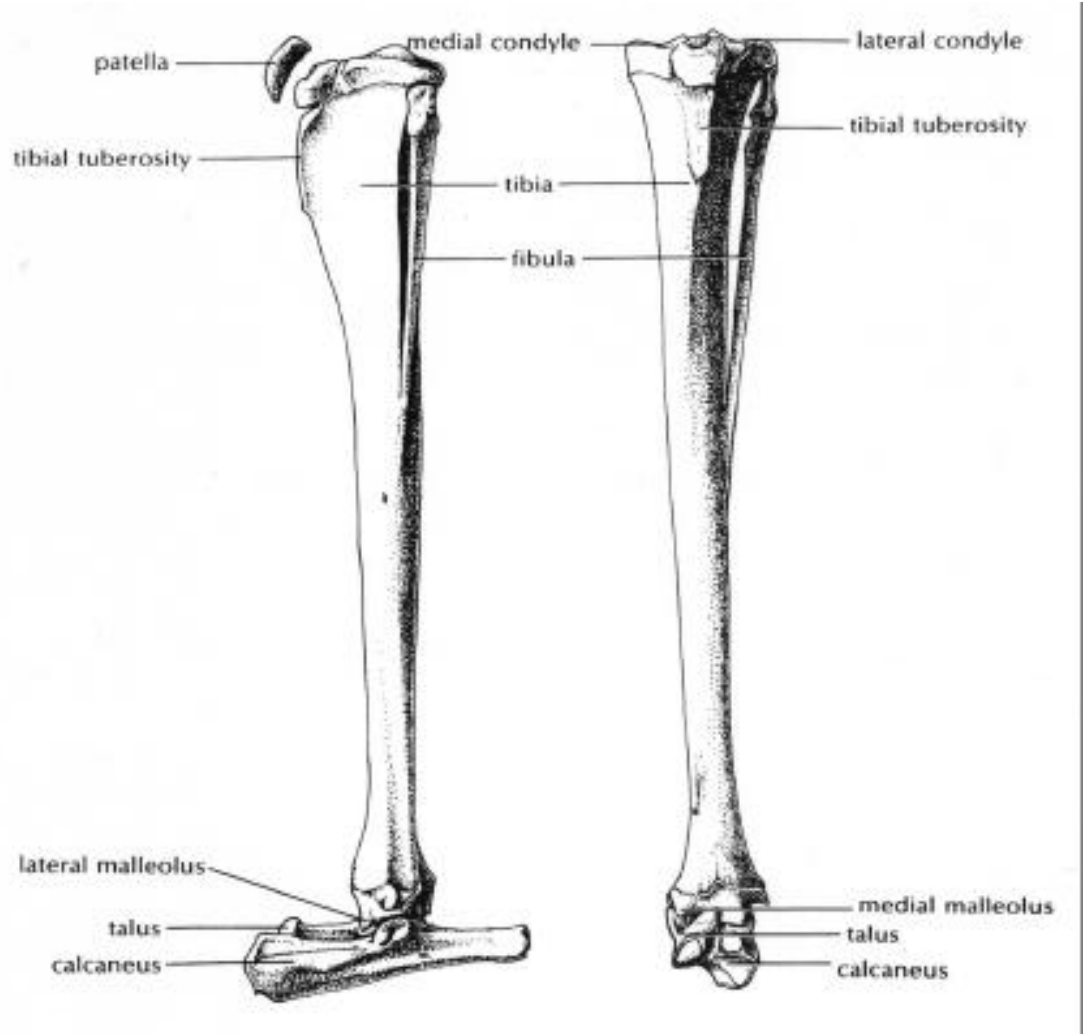

Proximal
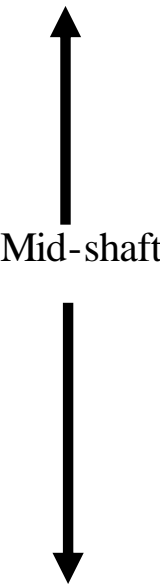

Distal

Figure 1.7 - 3: Definitions of locations and Anatomy of the Tibia (Wingerd and Stein 1985) 


\section{Chapter 2 Mechanical Testing}

\subsection{Bone as an Engineering Material}

Bone is anisotropic material. Bone is unique engineering material in that it has the ability to heal. Bone is also considered to be a composite material having fiber and matrix. The fibers are the osteons, and the remaining bone being the matrix.

\subsection{Introduction to Fracture Toughness testing}

A study done by Leonardo de Vinci with similar iron wires and found that the longer wire could not hold the same weight as the short wire. The theory was that the longer wire had a greater chance of having flaws thus weakening the material. Flaws cause higher localized the stresses. If the stress around the flaw is high enough, the material could fail well be before the ultimate strength is researched. Fracture mechanics is the study of unexpected failure in material due to preexisting flaws (Anderson 1991; Boresi and Schmidt 2003). Fracture toughness is a material property, which measures the ability to resist crack initiation and growth. Linear elastic fracture mechanics (LEFM) applies to materials that obey Hook's Law, and has a small plastic zone compared to the thickness. To ensure that LEFM theory can apply one must make sure that the plastic zone is contained and is not too large. Once the plastic zone becomes too large one must look at different theories to measure the stress at the crack tip. Elastic plastic fracture mechanics (EPFM) applies to material that shows time-independent and nonlinear behavior (plastic deformation). For most brittle materials fracture will occur at a critical stress. Most ductile materials plastic deformation will occur before fracture. In an ideally brittle material, a crack forms by breaking the atomic bonds, where $?_{\mathrm{s}}$ the amount 
of energy it is needed to break a bond (see figure 2.2 - 1a). A Quasi-brittle elastic plastic material shows both brittle and ductile behavior. The amount of work needed for a crack to grow in this material is both $?_{\mathrm{s}}$ and $?_{\mathrm{p}}$, where $?_{\mathrm{p}}$ is the plastic work (see figure $2.2-1 \mathrm{~b}$ ) and is the area right in front of the crack tip known as the plastic zone. In a real crack growth brittle material, occurs by meandering and branching. The amount of work it takes for the crack to grow is $?_{\mathrm{s}}$ (True area/Projected area) (see figure $2.2-1 \mathrm{c}$ ).

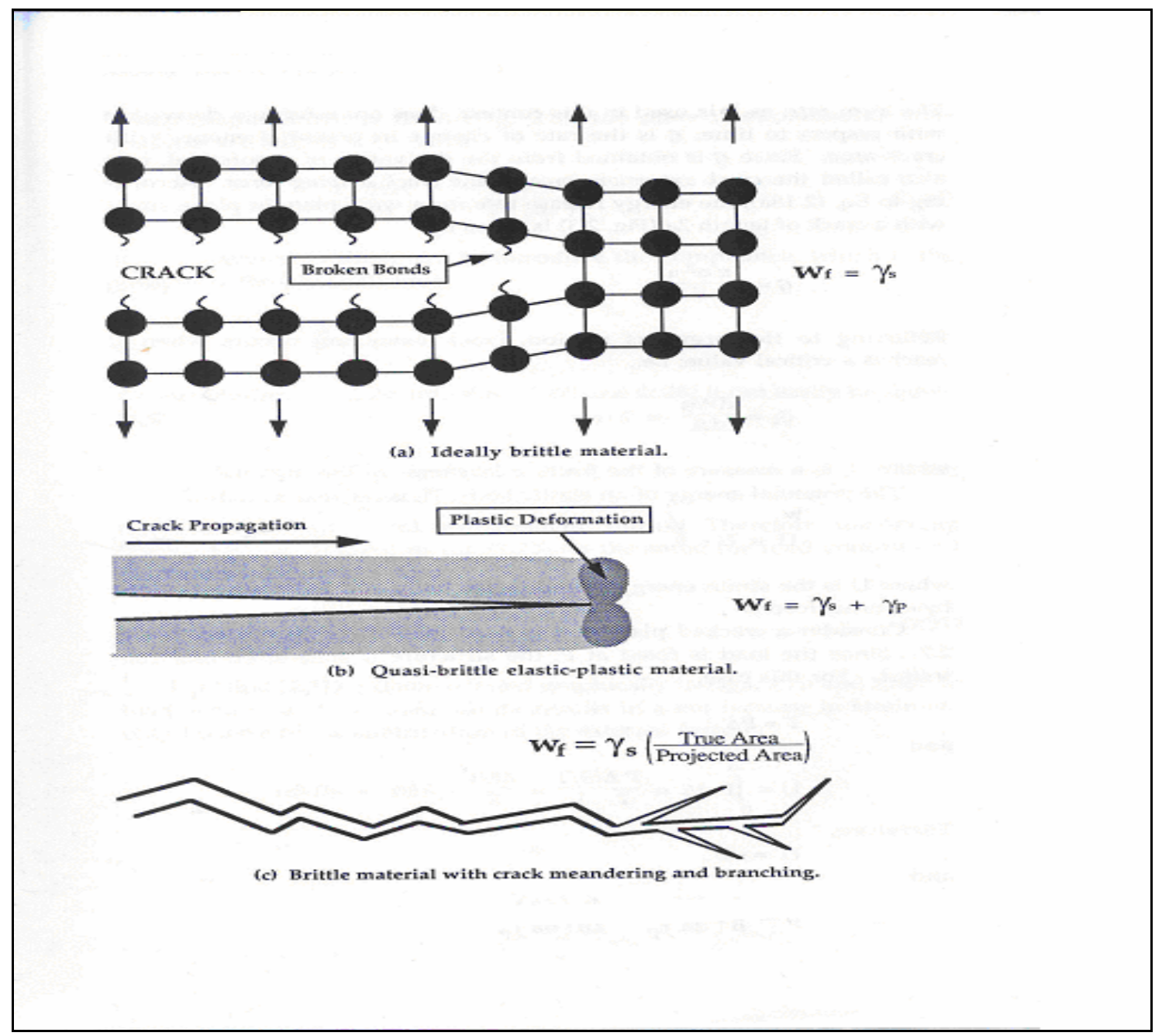

Figure 2.2 - 1: Crack growth in different type of materials (Anderson 1991) 


\subsubsection{Stress Concentration Factor}

The stress concentration factor is the elevated stress at a point divided by the remote normal stress equation 1 , and is a measure of the effect of the hole (defect) on the stress state. Stress concentration factor is found around the edge of a hole in a plate, with the hole having a finite radius (see figure 2.2.1 - 1).

$$
K=\frac{\sigma_{a}}{\sigma_{n o m}}(1)
$$

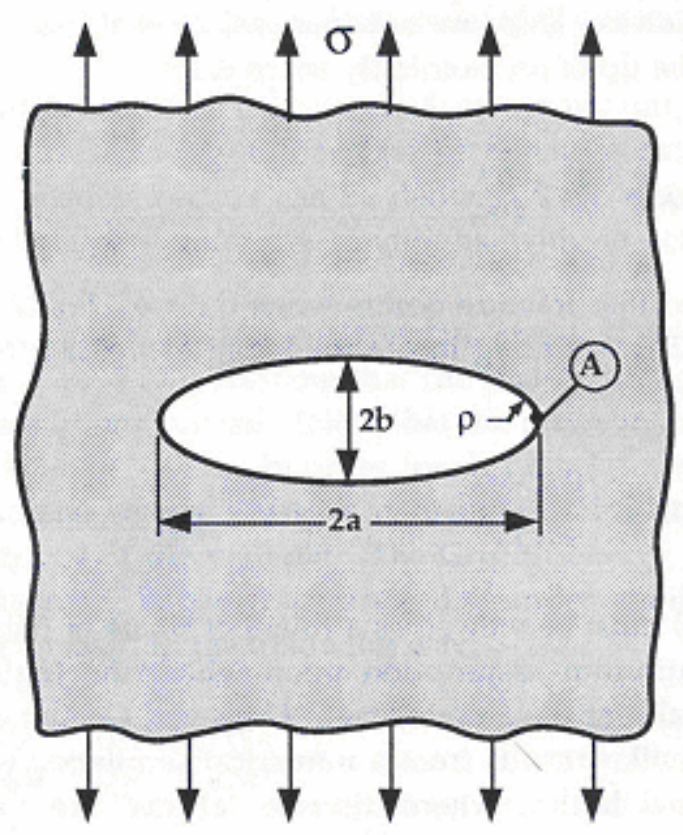

Figure 2.2.1 - 1: Elliptical hole in a flat plate (Anderson 1991)

To find the stress concentration factor around a hole at point A on figure 2.2.1 -1 in a plate the following equation is used.

$$
\sigma_{A}=\sigma\left(1+2 \sqrt{\frac{a}{\rho}}\right)
$$


Where in figure $\mathrm{s}$ is the stress applied, $\underline{a}$ is the major axis, $\underline{b}$ is the minor axis, and $\rho$ is the radius of curvature. This will give higher stress concentration at point $\mathrm{A}$.

When the radius of the hole approaches 0 thus forming a crack, the stress concentration factor will results in the stress around the crack tip to be infinite. This result is not useful because no material can withstand a stress of infinite. Therefore, this method does not give a usable number to determine the stress around the crack tip. A new method needs to be developed to determine the stress around a crack tip. The new method is fracture mechanics (fracture toughness). There are two ways to measure fracture toughness, the strain energy release rate and the stress intensity approach.

\subsubsection{Strain Energy Release Rate}

Griffith introduced the concept of strain energy release rate, G. The strain energy release rate is the amount of strain energy lost by members per unit area of the newly formed crack as the crack propagates i.e.

$$
G=-\frac{d \prod}{d A}
$$

where ? is the potential energy of an elastic body, and A is the crack area. The potential energy is defined as

$$
\Pi=U-F
$$

where $\mathrm{U}$ is the strain energy stored in the body, and F is the work done by external force. Figure 2.2.2 - 1 shows that the external work done is the load P multiplied by the displacement?

$$
F=P \Delta
$$

The strain energy is the area 


$$
U=\int_{0}^{\Delta} P d \Delta=\frac{P \Delta}{2}
$$

Thus the potential energy become

$$
\Pi=-U
$$

The strain energy release rate thus become

$$
G=\frac{1}{B} \cdot\left(\frac{d U}{d a}\right)_{P}=\frac{P}{2 B}\left(\frac{d \Delta}{d a}\right)_{P}
$$

Compliance is the inverse of the plate stiffness.

$$
C=\frac{\Delta}{P}
$$

Substituting compliance into (9) for P results in the strain energy release rate equation (10).

$$
G=\frac{P^{2}}{2 B} \cdot \frac{d C}{d a} \quad(10)
$$

Where $\mathrm{P}$ is the load, $\mathrm{B}$ is the thickness, $\mathrm{C}$ is the compliance, and $\underline{a}$ is the crack length. Rate in this content is not dependent on time but change of potential energy with crack area. Crack growth occurs when $\mathrm{G}$ reaches a critical value GC. 


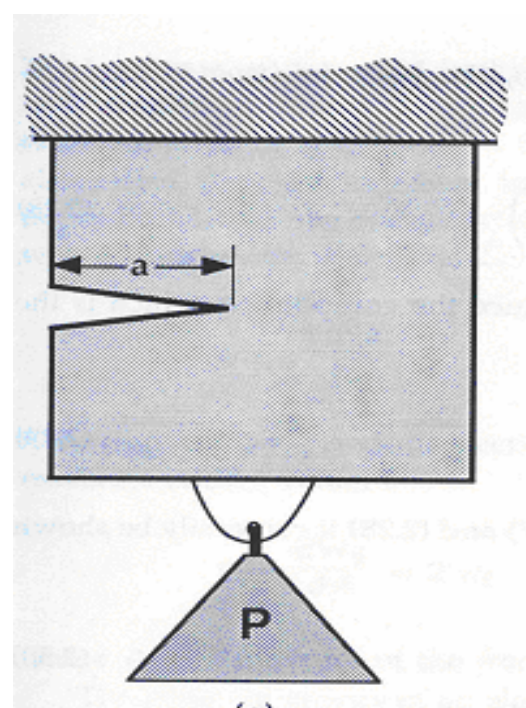

(a)

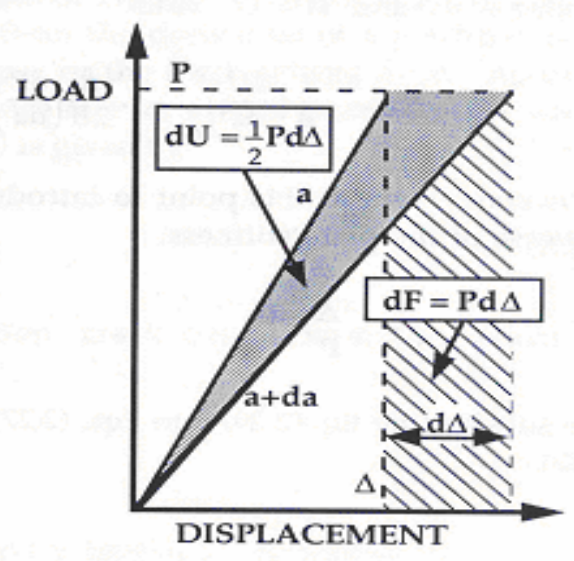

(b)

Figure 2.2.2 -1: Cracked plate with a fixed load P (Anderson 1991)

\subsubsection{Stress Intensity Factor}

The stress intensity factor is mechanical property predicts when a crack will self propagate. The higher the stress intensity factor value the higher the load is needed to get the crack to self propagate. To measure the stress intensity factor the specimen has to be in a state of plane strain.

The equation to determine the stress around the crack is

$$
\sigma_{i j}=\left(\frac{k}{\sqrt{\pi r}}\right) \cdot f_{i j}+\text { other terms }
$$

where $\mathrm{s}_{\mathrm{ij}}$ is the stress tensor, $\mathrm{r}$ and ? are defined by figure $2.2 .3-1, \mathrm{k}$ is the proportionality constant and $\mathrm{f}_{\mathrm{ij}}$ is dimensionless function. When $\mathrm{k}$ is replaced by the Stress intensity factor $\mathrm{K}$.

$$
k=\frac{K}{\sqrt{2 \pi}}(12)
$$


When $\mathrm{k}$ is placed in equation 11 it becomes equation 13 .

$$
K_{(I, I I \text { or III })}=C \cdot \sigma \sqrt{\pi a}
$$

Where $\mathrm{C}$ a is dimensionless constant that depends on geometry and mode of loading, $\sigma$ is the stress applied, and $\underline{a}$ is the crack length. As with $\mathrm{G}$ when $\mathrm{K}$ reaches its critical value, crack growth occurs and $\mathrm{K}=\mathrm{K}_{\mathrm{C}}$.

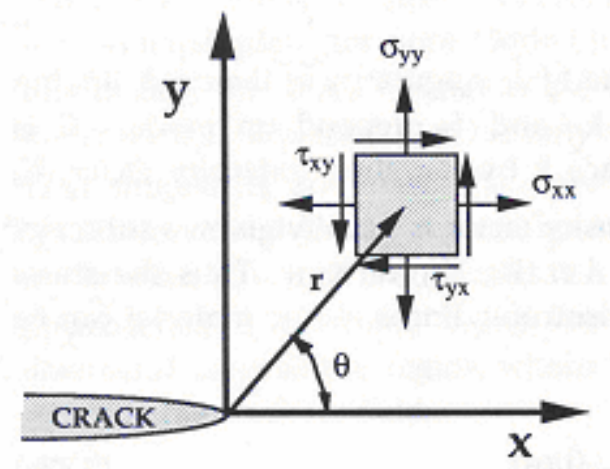

Figure 2.2.3 - 1: Coordinate definition in front of the crack tip (Anderson 1991)

The stress intense factor and the strain energy release rate can be related by the follow equation

$$
G=\frac{K^{2}}{E}
$$

There are three different type modes of crack growth, which are mode 1 (opening mode), mode 2 (sliding mode) and mode 3 (tearing mode) (figure 2.2.3 - 2). In this study we will be dealing with mode $1\left(\mathrm{~K}_{\mathrm{IC}}\right)$. 


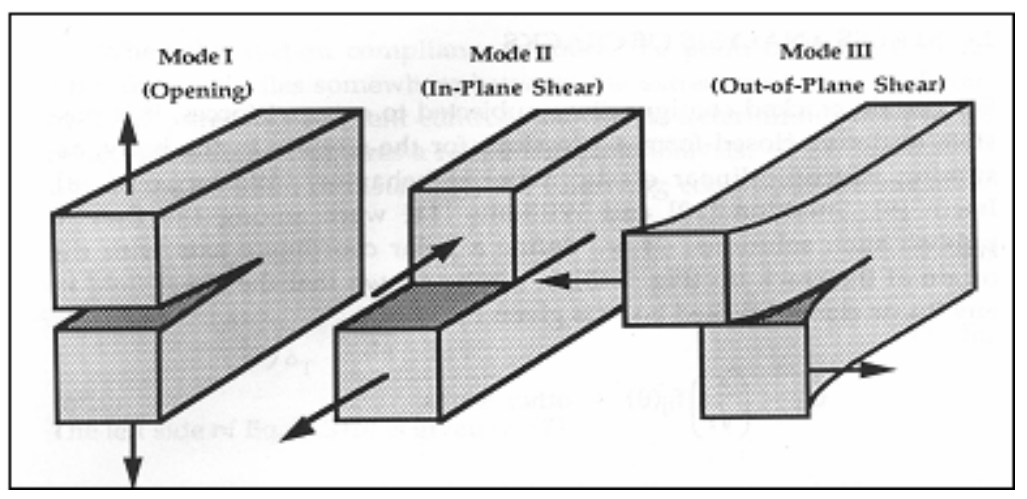

Figure 2.2.3 - 2: Three different testing modes (Anderson 1991)

The test specimen used to test for the fracture toughness in mode 1 is known as the compact tension (CT) specimen (figure 2.2.3 - 3).

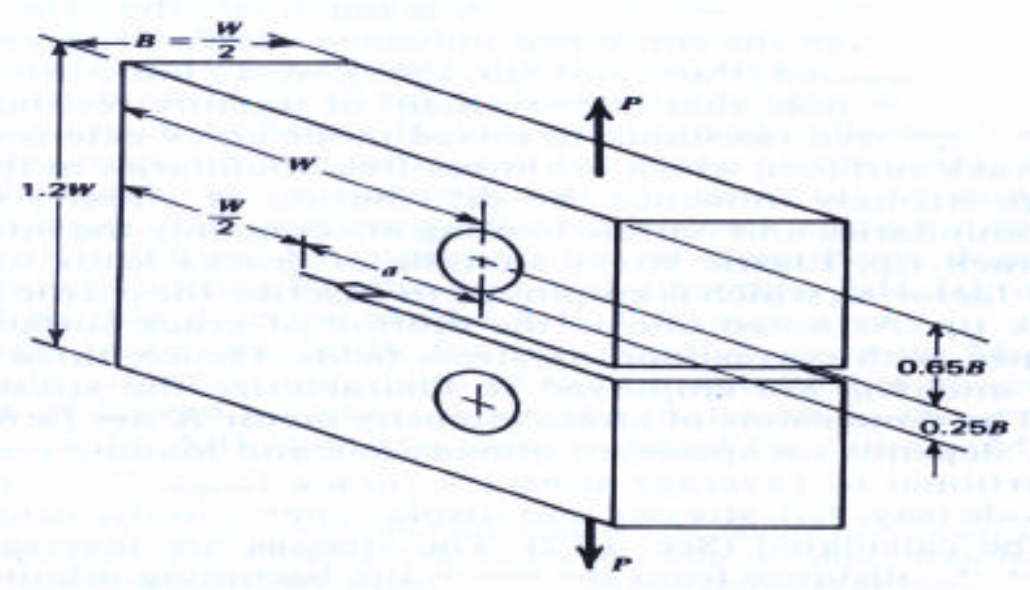

Figure 2.2.3 - 3 CT specimen and dimensions

The equation used to calculate the fracture toughness of a material in mode I crack growth is

$$
K_{I C}=\frac{P_{Q}}{B \cdot \sqrt{W}} \cdot f(a / W)
$$


where $\mathrm{P}_{\mathrm{Q}}$ is the critical load, $\mathrm{B}$ is the thickness, $\mathrm{W}$ is the length between the applied load and the end of the specimen and $\mathrm{f}(\mathrm{a} / \mathrm{W})$ is a dimensionless function of $\mathrm{a} / \mathrm{W}$. The equation for $\mathrm{f}(\mathrm{a} / \mathrm{W})$ is

$f\left(\frac{a}{W}\right)=29.6 \cdot\left(\frac{a}{W}\right)^{.5}-185.5\left(\frac{a}{W}\right)^{1.5}+655.7\left(\frac{a}{W}\right)^{2.5}-1017\left(\frac{a}{W}\right)^{3.5}+638.9\left(\frac{a}{W}\right)^{4.5}$

If $\mathrm{K}$ equals $\mathrm{K}_{\mathrm{C}}$ then the crack will propagate. Tests can be done for each material to determine the critical value for $\mathrm{K}$ known as fracture toughness, or $\mathrm{K}_{\mathrm{IC}}$, for mode $\mathrm{I}$ loading. The American Society of Testing Mechanics (ASTM) standard E-399 gives guidelines on how to make the compact tension specimen. Certain dimensions have to be meet for the test to be valid. To make a compact tension specimen, size requirement have to be met to make sure the specimen is in the plane strain regions (see figure 2.2.3-4). $\mathrm{K}$ has been shown to linearly increase with increasing width of the specimen up to a certain thickness during the Plane Stress stage 1. Once a certain thickness has been reached a transitional stage 2 begins, where $\mathrm{K}$ begins to decrease. Once the $\mathrm{K}$ begins to level off then you enter the Plane Strain stage 3 when $K$ is a constant equals $K_{I C}$. 


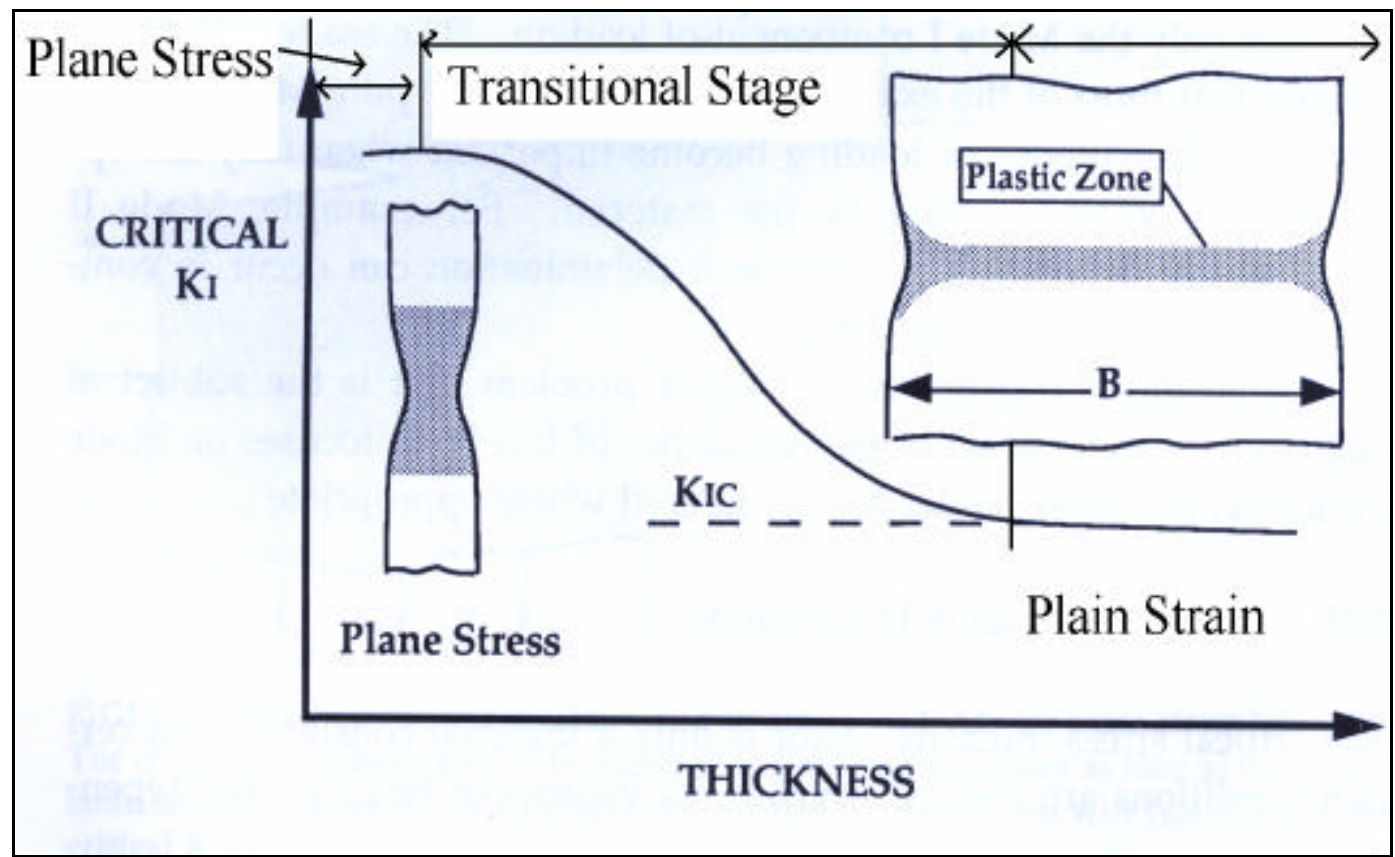

Figure 2.2.3 - 4: Regions for $K_{\mathrm{IC}}$ of plain strain and stress (modification made) (Anderson 1991)

Most cracks are in 3-dimension however, in a compact tension specimen assume the crack propagates is in 2-dimensions. In the plane strain case all the values of strain in the $\mathrm{z}$ direction are equal to zero and the plastic zone is small compared to the thickness. The plane stress stage is where the stress values in the $\mathrm{z}$ direction are zero. The Plane stress exists if the plastic zone is in the same order as the thickness. To ensure that the specimen is in plane strain mode the thickness of the specimen must be equal to half of $\mathrm{W}$, or if $\mathrm{K}_{\mathrm{IC}}$ is given the thickness must be greater than or equal to thickness found in equation (15).

$$
a, B,(W-a) \geq 2.5 \cdot\left(\frac{K_{I C}}{\sigma_{y s}}\right)^{2}
$$

Other requirements for compact tension specimen is that the a/W must be between

$$
0.45=\mathrm{a} / \mathrm{W}=0.55
$$


Norman found in 1991, that for CT specimen of $17.5 \mathrm{~mm}$ by $16.8 \mathrm{~mm}$ the minimum thickness needed to obtain plane strain of bovine bone is $7 \mathrm{~mm}$, which is difficult to do in most animals and humans (Norman 1991). The correct thickness needed for these specimens to ensure plan stress state is $2.25 \mathrm{~mm}$ but this can not be obtained because most rabbits bone are about $1 \mathrm{~mm}$ thick. The thickness of this studies specimen will be .5 $\mathrm{mm}$, while the $\mathrm{W}$ will be $5.5 \mathrm{~mm}$. These specimens may not satisfy the requirements for plain strain fracture toughness, but this does not mean that comparison within groups is not valid.

The plastic zone correction factor takes into effect for mode I test by $\mathrm{P}_{\max }$ must be

$$
\mathrm{P}_{\max }=1.10 \mathrm{PQ}(19)
$$

this is to allow for corrections for the plastic zone effects and deviations from the linearity in the load displacement curve. To obtain PQ for the equation, find it on a load displacement curve. There are three different load-displacement curves for the fracture toughness test shown in figure 2.2.3-4. 


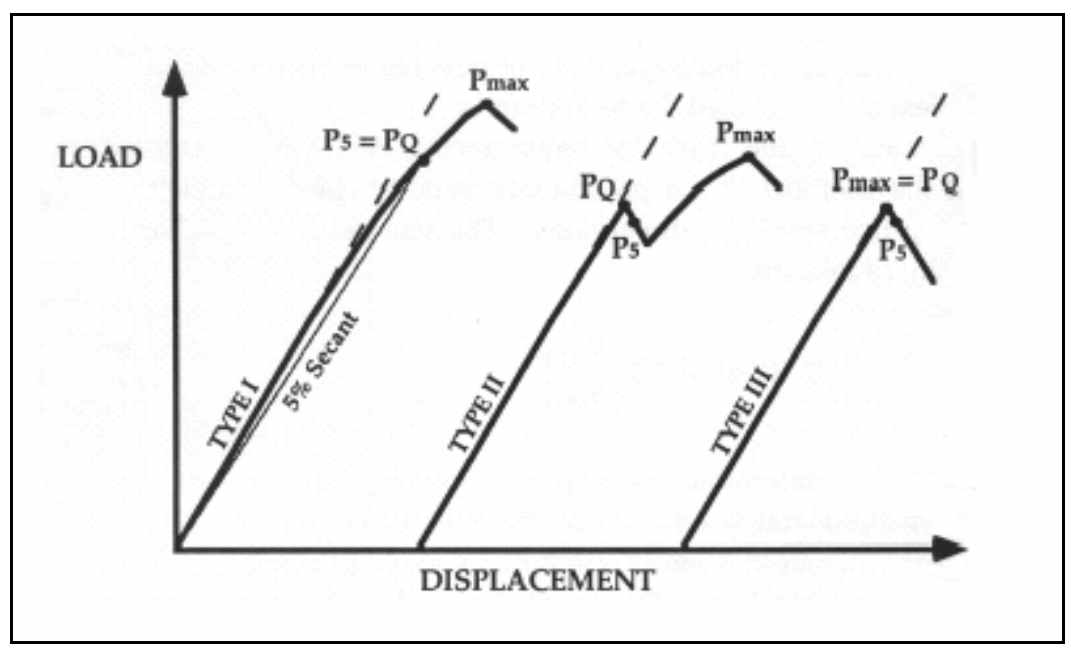

Figure 2.2.3 - 5: Three different loads versus displacement curves for fracture toughness test with the 5\% secant line. (Anderson 1991)

Once the linear portion for the load displacement curve is found and it is multiplied by .95. The new load displacement curve is plotted onto the original curve and used to find the PQ shown in figure 2.2.3 - 5. The high noise seen in figure $2.2 .3-6$ is due the to the small displacement. 


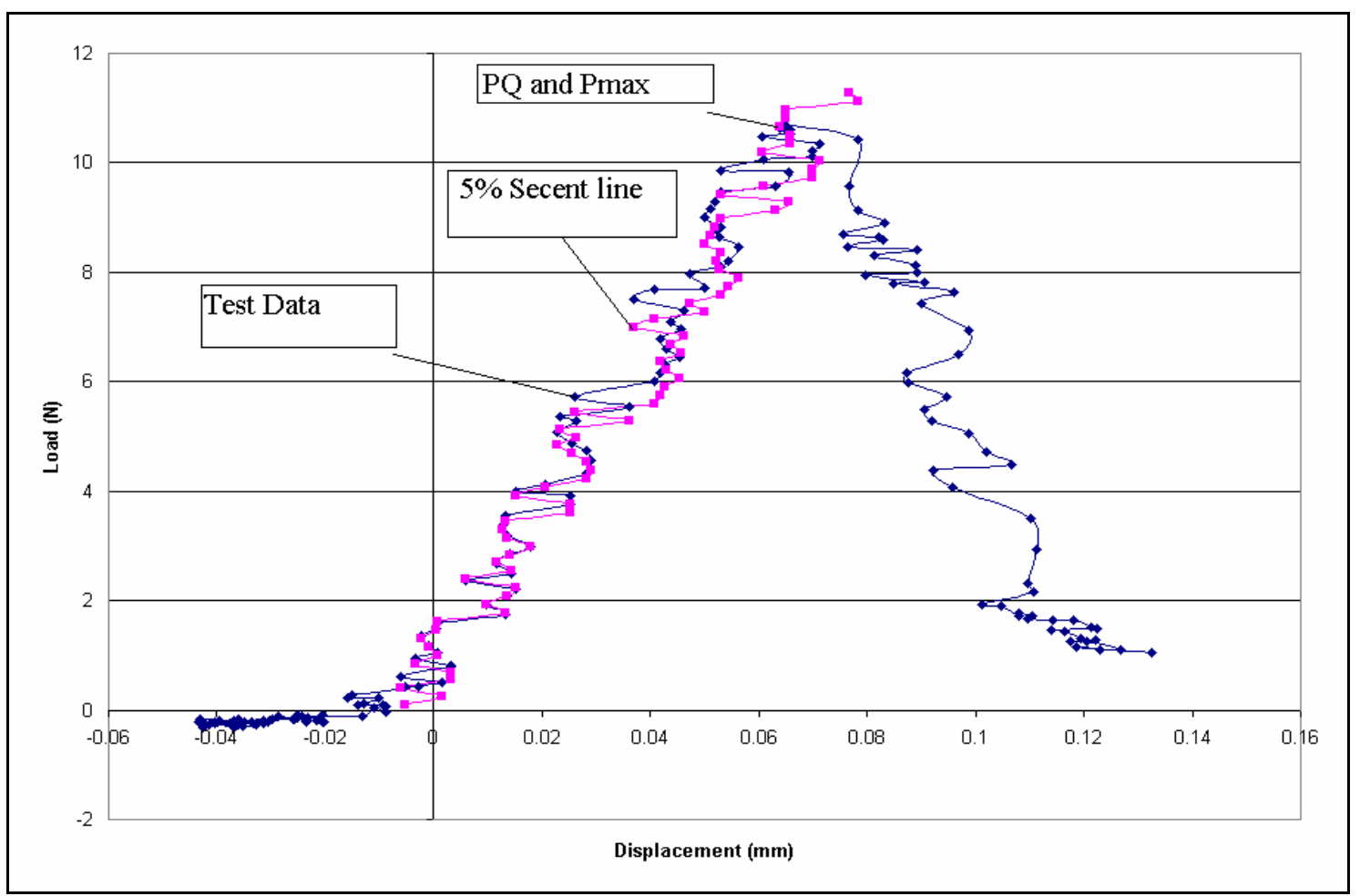

Figure 2.2.3 - 6: Fracture toughness result with the 5\% secant line plotted

Fracture toughness values are dependent on material microstructure. For an isotropic material specimen orientation doesn't matter. Since bone is considered to be a transversely isotropic, fracture toughness does depend on specimen orientation i.e. direction that a crack is propagated the fracture toughness value will depend on (Behiri and Bonfield 1989). The different direction that cracks can be propagated is shown in figure 2.2.3 - 7. The direction that these specimens will be tested is C-L. 


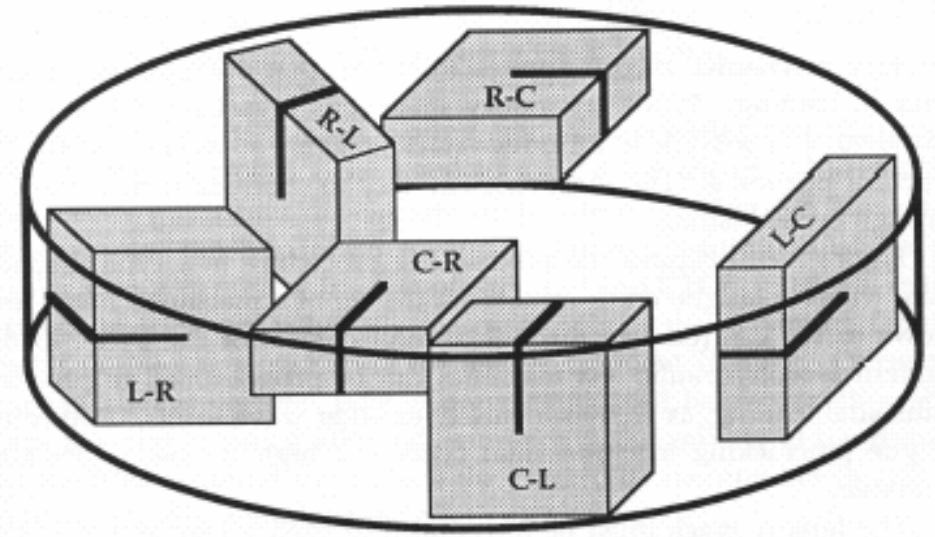

Figure 2.2.3 - 7: ASTM notation for specimen obtained from a disks and hollow cylinders (Anderson 1991)

\subsubsection{Fracture Toughness of bone}

Several studies have been performed to elucidate how microstructural features of cortical bone influence clinical fractures. Barth (Barth, Williams et al. 1992) found that people who fracture the hip have larger haversian canals and lower osteon density than the other groups. Crabtree (Crabtree, Loveridge et al. 2001) found that in hip fracture cases that people who fracture their hip have the same amount of cancellous bone left, as do non-fractures, but the amount of cortical bone is different by $15 \%$. This show that the cortical bone is an important factor in hip fracture cases.

Responding to these studies, several studies were performed to correlate clinical finding to mechanical behavior to measure fracture fragility i.e. fracture toughness. Yeni, Brown, and Norman (Yeni, Brown et al. 1997; Yeni, Brown et al. 1998; Yeni and Norman 2000) conducting a number of studies to find the effects of bone morphology, composition, influence of microdamage, and bone location on bones fractures toughness. The following in Table 2.2.4 - 1, is a fracture toughness values chart for many different 
tests done in the past years, and table $2.2 .4-2$ is a summary of different studies fracture toughness.

The bone morphology effects are the following. The higher the osteon density the higher strain energy release rate and the higher the $\%$ of porosity the lower the strain energy release rates.

The bone composition effects are the following. Also found was that the strain energy release rate is affected by the apparent density, amount of $\mathrm{H}_{2} \mathrm{O}$, and age of the bone. The strain energy release rate increased with wet or dry density increase. The strain energy release rate also decreased with an increase in water content.

The microdamage effects are the following. Microdamage of bone also had an effect on the strain energy release rate; as the microdamage density went up the strain energy release rate went down. In addition, as the micocrack length increased the strain energy release rate went down.

The bone locations are the following. Fracture toughness was also found to depend on where the specimen is taken. The fracture toughness values for femoral neck were the highest while the lowest fracture toughness values was in the femoral shaft (Brown, Yeni et al. 2000).

Table 2.2.4 - 1: Different variable effect on fracture toughness.

\begin{tabular}{|l|l|l|}
\hline Variable & Increase & Effect on fracture toughness or Strain energy release rate \\
\hline microdamage density $\left(\# / \mathrm{mm}^{\wedge} 2\right)$ & increase & decrease \\
\hline microdamage surface density $(1 / \mathrm{mm})$ & increase & decrease \\
\hline Average micorcrack length $(\mathrm{mm})$ & increase & decrease \\
\hline porosity $\%$ & increase & decrease \\
\hline Age & increase & decrease except for the femural neck \\
\hline dry density & increase & increase \\
\hline$\% \mathrm{H} 20$ & increase & decrase in mode I \\
\hline osteon density $\left(\# / \mathrm{mm}^{\wedge} 2\right)$ & increase & increase femur only \\
\hline wet density & increase & increase \\
\hline
\end{tabular}


Table 2.2.4 - 2: Stress Concentration Factors for the Literature for the Tibia (Yeni 1998)

\begin{tabular}{|c|c|c|c|c|c|}
\hline Author(s) & Species & Experiment & Measurement & Direction & Loading Rate \\
\hline $\begin{array}{c}\text { Bonfield \& Datta } \\
(1974)\end{array}$ & Bovine & Center Notched Shock Tube & $\mathrm{Kc}=0.23$ & Longitudinal & $\sim 7 s^{\wedge}-1$ \\
\hline $\begin{array}{c}\text { Bonfield \& Datta } \\
(1976)\end{array}$ & Bovine & Single-edge Notched & $\mathrm{Kc}=2.2-4.6$ & Transverse & $3 e-3 s^{\wedge}-1$ \\
\hline $\begin{array}{c}\text { Behiri \& Bonfield } \\
(1980)\end{array}$ & Bovine & CT & $\mathrm{Kc}=4.46-5.38$ & Longitudinal & $\begin{array}{c}0.0102-1.02 \\
\mathrm{~mm} / \mathrm{min}\end{array}$ \\
\hline $\begin{array}{c}\text { Behiri \& Bonfield } \\
(1982)\end{array}$ & Bovine & CT & $\mathrm{Kc}=3.3-5.7$ & Longitudinal & \\
\hline $\begin{array}{c}\text { Behiri \& Bonfield } \\
(1984)\end{array}$ & Bovine & CT & $\mathrm{Kc}=2.8-6.3$ & Longitudinal & $\begin{array}{l}0.01-50 \\
\mathrm{~mm} / \mathrm{min}\end{array}$ \\
\hline \multirow{2}{*}{$\begin{array}{l}\text { Bonfield et al. } \\
\text { (1985) }\end{array}$} & Human & CT & $\mathrm{Kc}=2.1-4.7$ & Longitudinal & $\begin{array}{l}0.504 \mathrm{e}-3 \\
\mathrm{~mm} / \mathrm{min}\end{array}$ \\
\hline & Canine & CT & $\mathrm{Kc}=3.2-6.5$ & Longitudinal & $\begin{array}{l}0.0102 \\
\mathrm{~mm} / \mathrm{min}\end{array}$ \\
\hline $\begin{array}{c}\text { Moyle \& Gavens } \\
(1986)\end{array}$ & Bovine & Single-edge Notched & $\mathrm{Kc}=11.2$ & Transverse & $0.45 \mathrm{~mm} / \mathrm{min}$ \\
\hline $\begin{array}{c}\text { Behiri \& Bonfield } \\
(1989)\end{array}$ & Bovine & CT (grooved) & $\mathrm{Kc}=3.2$ & Longitudinal & $\begin{array}{l}0.0198 \\
\mathrm{~mm} / \mathrm{min}\end{array}$ \\
\hline $\begin{array}{l}\text { Norman et al } \\
\quad(1991)\end{array}$ & Human & CT & $\mathrm{Kc}=4.48$ & Longitudinal & $0.5 \mathrm{~mm} / \mathrm{min}$ \\
\hline $\begin{array}{c}\text { Norman et al } \\
(1991)\end{array}$ & Human & $\begin{array}{c}\text { CT (corrected for } 7 \mathrm{~mm} \\
\text { thickness) }\end{array}$ & $\mathrm{Kc}=3.68$ & Longitudinal & $0.5 \mathrm{~mm} / \mathrm{min}$ \\
\hline $\begin{array}{c}\text { Norman et al } \\
(1992)\end{array}$ & Bovine & CT & $\mathrm{Kc}=5.3-9.4$ & Longitudinal & $0.5 \mathrm{~mm} / \mathrm{min}$ \\
\hline $\begin{array}{c}\text { Norman et al } \\
(1992)\end{array}$ & Bovine & CT (grooved) & $\mathrm{Kc}=5.2-9.3$ & Longitudinal & $0.5 \mathrm{~mm} / \mathrm{min}$ \\
\hline $\begin{array}{c}\text { Valishth et al } \\
(1994)\end{array}$ & Bovine & CT & $\mathrm{Kc}=4-7.6$ & Longitudinal & $0.5 \mathrm{~mm} / \mathrm{min}$ \\
\hline $\begin{array}{c}\text { Valishth et al } \\
(1994)\end{array}$ & Human & CT & $\mathrm{Kc}=1.6-2.5$ & Longitudinal & $0.5 \mathrm{~mm} / \mathrm{min}$ \\
\hline $\begin{array}{c}\text { Norman et al } \\
(1995 b)\end{array}$ & Bovine & CT & $\mathrm{Kc}=4.68-6.73$ & Longitudinal & $2.6 \mathrm{~mm} / \mathrm{min}$ \\
\hline $\begin{array}{l}\text { Norman et al } \\
(1995 b)\end{array}$ & Human & CT & $\mathrm{Kc}=4.05-4.32$ & Longitudinal & $2.6 \mathrm{~mm} / \mathrm{min}$ \\
\hline $\begin{array}{c}\text { Feng \& Salzmann } \\
(1995)\end{array}$ & Bovine & CT & $\mathrm{Kc}=2.55$ & Longitudinal & $0.2 \mathrm{~mm} / \mathrm{min}$ \\
\hline $\begin{array}{c}\text { Norman et al } \\
(1996)\end{array}$ & Human & CT & $\mathrm{Kc}=2.12$ & Longitudinal & $0.2 \mathrm{~mm} / \mathrm{min}$ \\
\hline
\end{tabular}




\subsubsection{Methods fracture toughness preparation}

The first testing group of eighteen New Zealand white rabbits were used in this study group I. The rabbits were divided up into 4 groups. The first groups was a control group with $\mathrm{n}=3$, the $5.25 \mathrm{mg}$ group had $\mathrm{n}=4,10.5 \mathrm{mg}$ group had $\mathrm{n}=5$, and the $21 \mathrm{mg}$ group had $n=6$. The specimens where randomly tested. The patches were placed on the inside of the rabbits' ear and changed every day.

The second testing group of twenty-six rabbits and where divided up into controls $\mathrm{n}=5$, nicotine delivered via patches $\mathrm{n}=9(10.5 \mathrm{ng} / \mathrm{ml})$, nicotine delivered via cigarette $\mathrm{n}$ $=6$ (Group II) for 4 weeks in the chamber, and nicotine delivered via cigarette $n=6$ (Marlboro filter cigarettes) in the chamber for 5 weeks. The $10.5 \mathrm{ng} / \mathrm{ml}$ patch was used in this study because it gave the most constant levels of nicotine. The smoking chamber could only hold 6 rabbits. The first groups of rabbits only got 4 weeks of cigarette smoke which they started a week after there surgery. This was due to moving the chamber around to place where it could be used. This group also only got second hand smoke for 3 weeks and for the last week got both first and second hand smoke. The second group was in the chamber for the full 5 weeks. This group got both first and second hand smoke for all 5 weeks. The rabbits that received the cigarette smoke stayed in the smoking chamber created here at the lab, for 6 hrs a day 5 days a week. The specimens where randomly tested. The rabbits patches where changed every day and the rabbits in the chamber were constantly monitor every day while the rabbits where in the chamber.

During the 5 weeks after their surgery the rabbits' nicotine level was measured at the 1,3 , and 5 week interval. The daily average nicotine serum level for heavy smokers is $10-70 \mathrm{ng} / \mathrm{ml}$ (Benowitz and Jacob 1984; Daftari, Whitesides et al. 1994; Sipe, Buck et 
al. 2000). In appendix $A$ is the nicotine level for each rabbit at 1, 3, and 5 weeks, and average nicotine level. All test specimens, at all times, were keep in a $.9 \%$ saline solution during all stages of specimen preparation and testing. Fracture Toughness test were done using the right tibia. A procedure was developed for the machining procedure that will be used for this project (Smith 2003). The specimen was machine down to the dimensions in figure 2.2.5 - 1. The specimen is taken from the flat lateral aspect of the proximal tibia adjacent to the fibula figure $2.2 .5-2$.

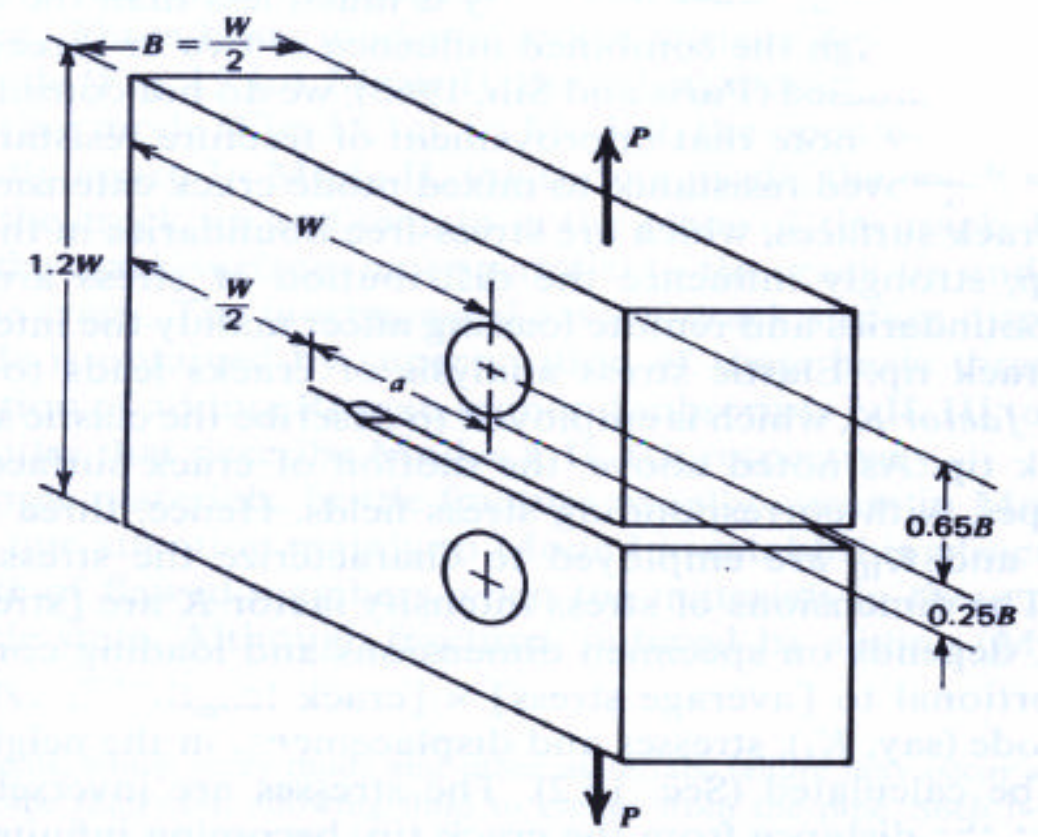

Figure 2.2.5 - 1: Dimensions of the fracture toughness specimen (Boresi and Schmidt 2003) W equals $5.5 \mathrm{~mm}$ 


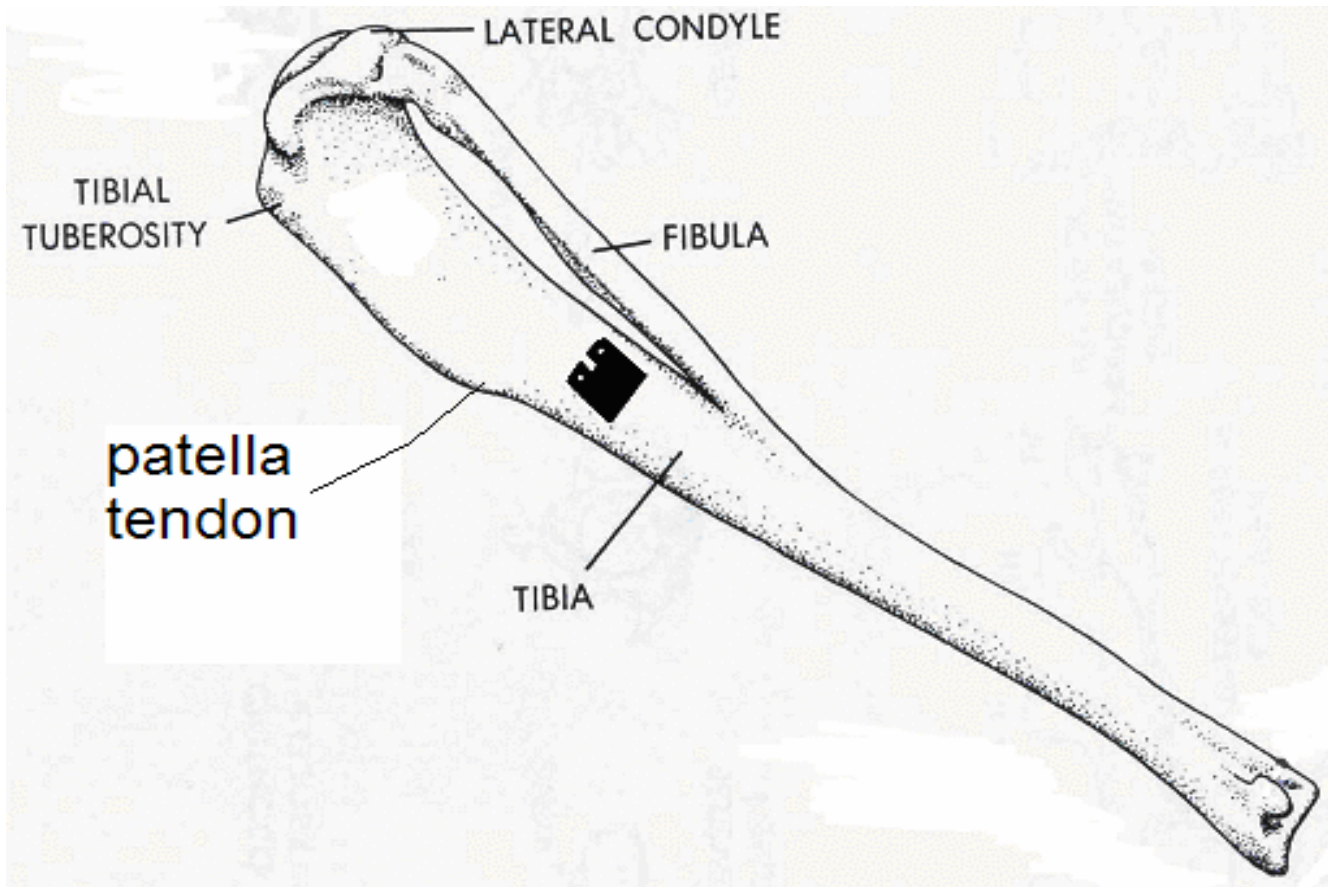

Figure 2.2.5 - 2: Location of the fracture toughness specimen on the tibia with adaptation with CT specimen (Wingerd and Stein 1985)

First, the proximal end of the tibia has been cut off just below the patella tendon attachment (see figure 2.2.5 - 2). These cuts were done by using a band saw/sander 12' blade (Sears/Craftmen). The band saw was used to cut the tibia down the center of the long axis of the bone and then cut once more to remove the specimen from the tibia. Next the specimen's width is trimmed to about $6 \mathrm{~mm}$ using the band saw, and then is trimmed down even more by using sandpaper to achieve $5.5 \mathrm{~mm}$. After that the specimen external cortex is flattened by sandpaper. Once the external cortex side is flattened down the specimen is placed into a fixture (Smith 2003) that will hold the specimen while it is being milled on slow speed $(260 \mathrm{rpm})$ to the correct thickness. The milling is done on a Bridgeport milling machine (Bridgeport Machine Inc., Bridgeport, CT). 
After the specimen is milled to the uniform thickness, holes are drilled into it using a $1 \mathrm{~mm}$ drill bit at high speeds on the mill $(2300 \mathrm{rpm})$ (see figure $2.2 .5-3)$. While in the mill, pencil marks are placed on the specimen to mark length, which is $6.8 \mathrm{~mm}$ (see figure 2.2.5 - 3). After the marks are in placed on the specimen they are cut using an Isomet Low Speed Saw (Buehler LTD, Evanston, IL). Next the specimen have a chevon notch (see figure 2.2.5 - 3) placed in the center between the two drilled holes using the Isomet Low Speed Saw. Finally after the chevon notch is cut a precrack (see figure 2.2.5 - 3) will be placed in the specimen by a razor blade.

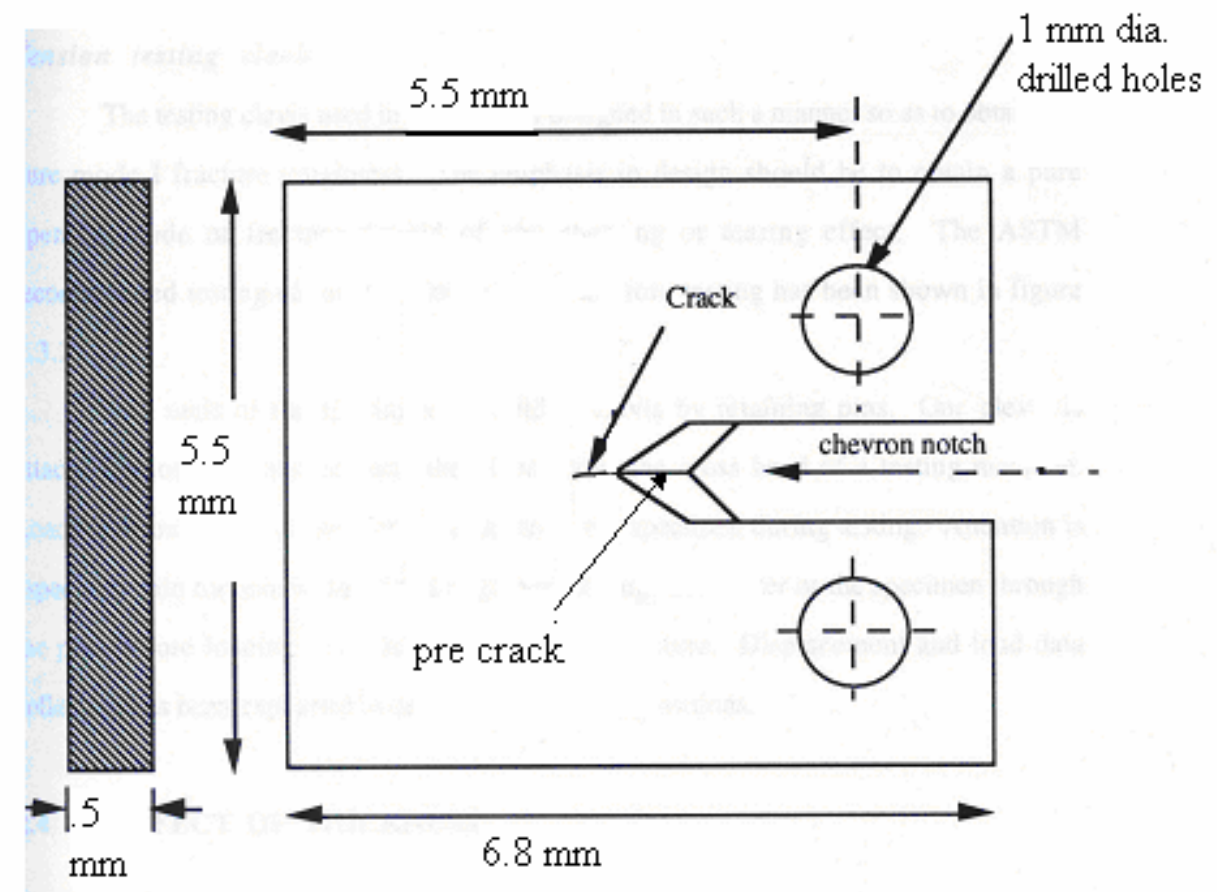

Figure 2.2.5 - 3: CT specimen made with dimension added (Vashishth 1991)

The specimen is then tested on the MTS machine model 812.21 (MTS Systems Corporation Minneapolis, MN). The specimen is loaded using a rate of $.2 \mathrm{~mm} / \mathrm{min}$. The data is collected an Analog to Digital board converter model PC-CARD-DAS 16/16-AO 
(Computer Measurement Corp, Middleboro, MA) and uploaded to a Labtech

NOTEBOOK pro software (Laboratory Technologies Corporation, Wilmington, MA) on

a Dell model 3500 Insperiron Computer (Dell, U.S.A). The data that will be collected from this test is the load to failure.

\subsubsection{Smoking Chamber}

The smoking chamber is a BioClean, DuoFlo, model H 5500, Lab Product Inc (figure 2.2.6-1).

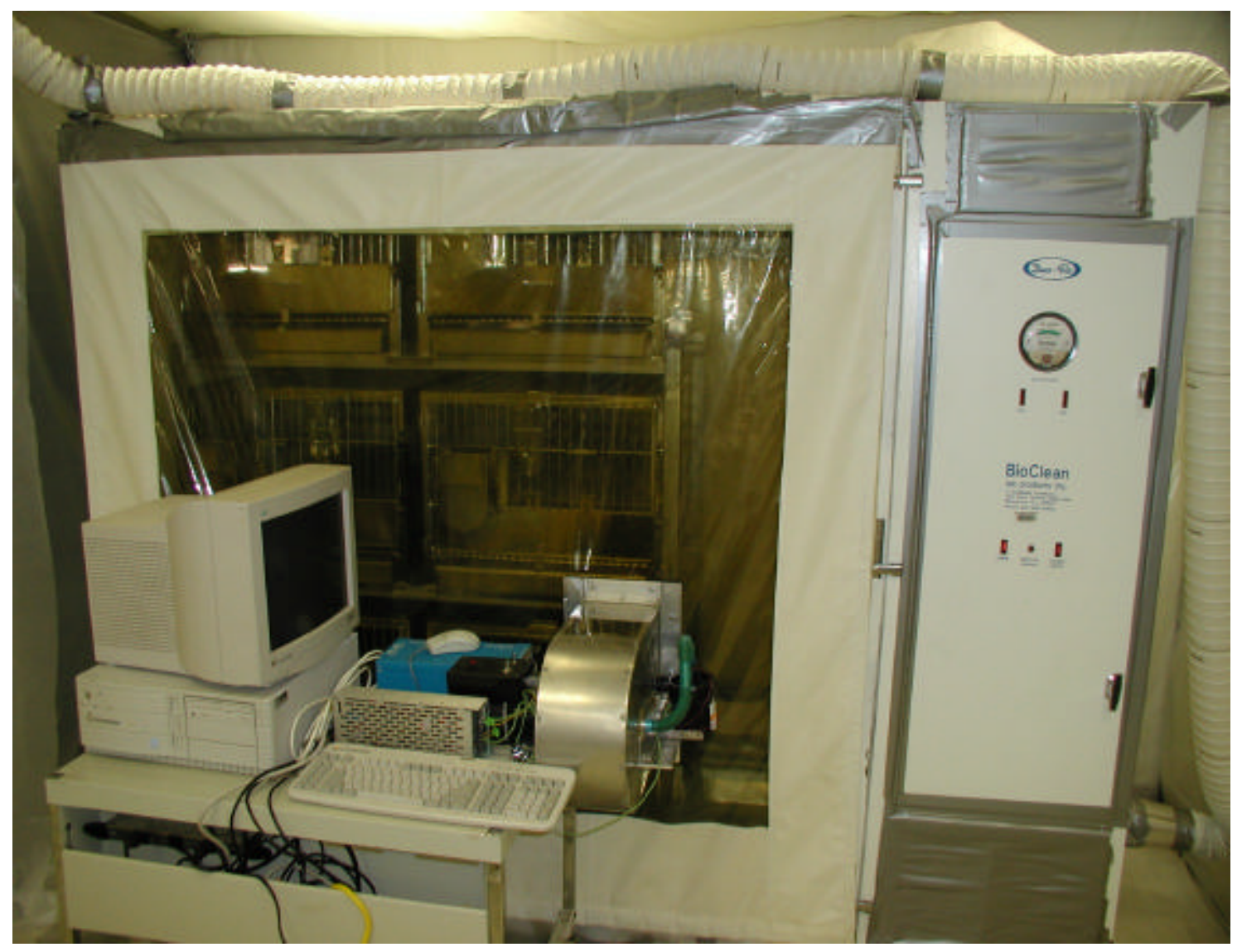

Figure 2.2.6 - 1: Smoking Chamber

The inside of the chamber measured was 1.92X1.92X.097 m

$\left(3.58 \mathrm{M}^{3}\right)$ and in this study could hold six rabbits. The rabbits were rotated clockwise in the cage to ensure uniform dosage.The rabbits were exposed to sidestream smoke (second 
hand smoke) from Marlboro filter cigarettes. The device used to light the cigarettes and was used to vent smoke into the chamber (figure 2.2.6 - 6). This device lit 4 cigarettes every 15 minutes for 6 hrs a day. A fan was used to mix the smoke in the chamber. The CO levels were monitored and keep to an average of about 50 part per million. The smoking chamber was model after Hutchison study (Hutchison and Reitz 1997).

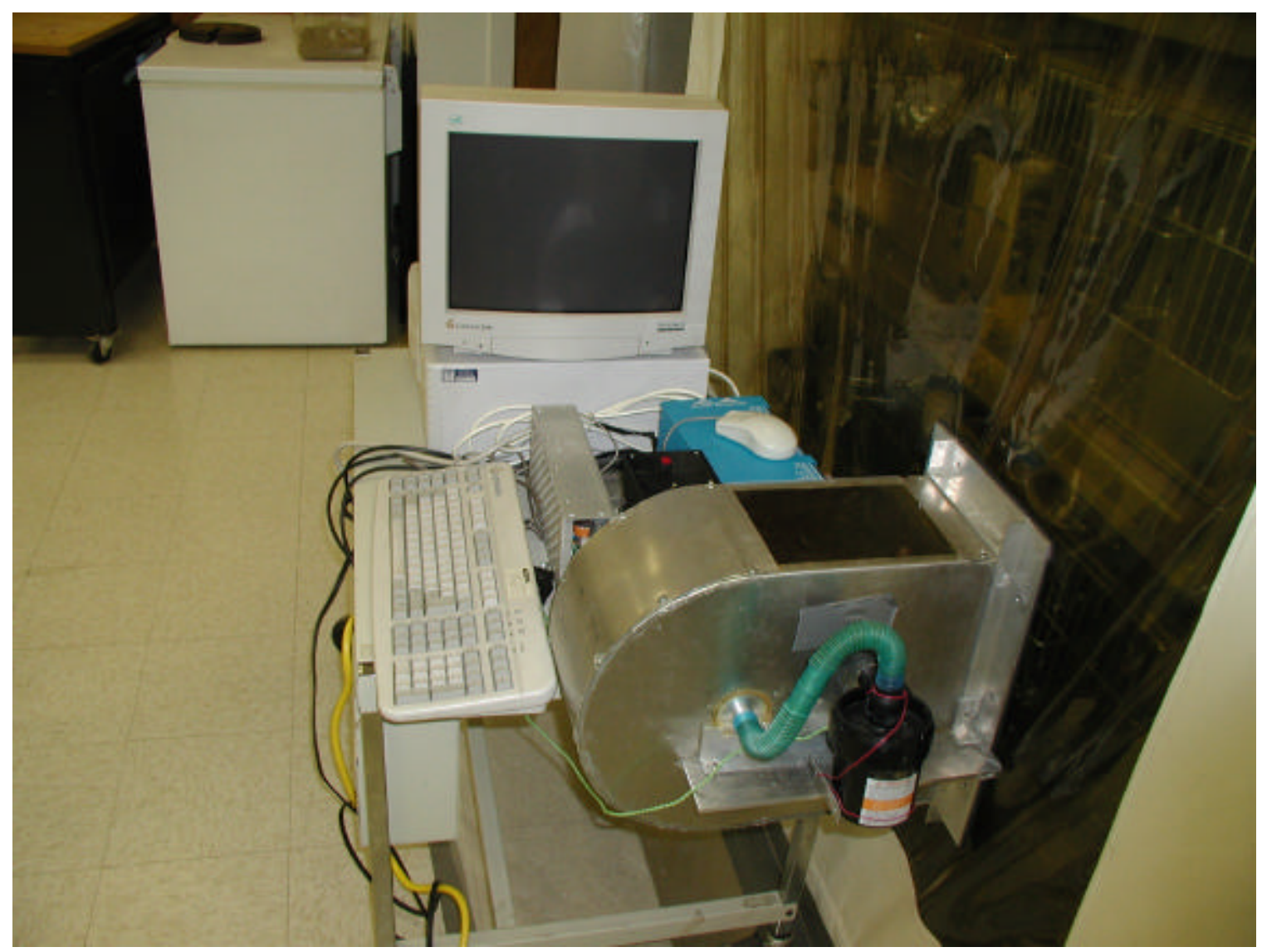

Figure 2.2.6 - 2: Device to light the cigarettes. 


\subsection{Introduction to 3 point bending test}

This test measures the strength and stiffness of the femur (figure $2.3-1$ ).

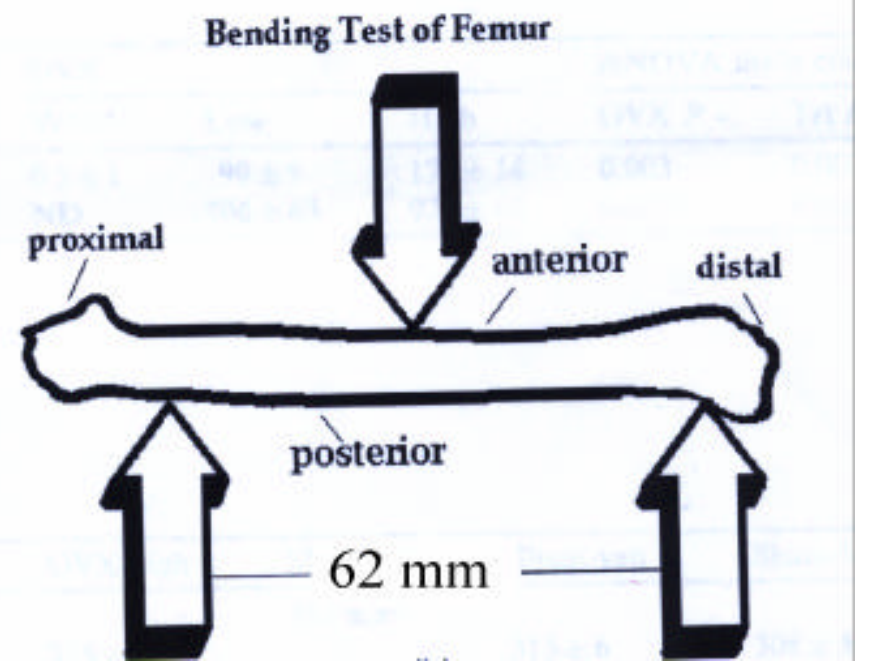

Figure 2.3 - 1: 3-point bending test set up (Akhter, Iwaniec et al. 2003)

To calculate the bone area was assumed to be a hollow ellipse. To find the cross section area of bone it had to be embedded and then stained. This will be explained in more detailed in sections 3.3.1 and 3.3.3. Once the bone is stained some measurements were taken using a microscope and the program optimums.

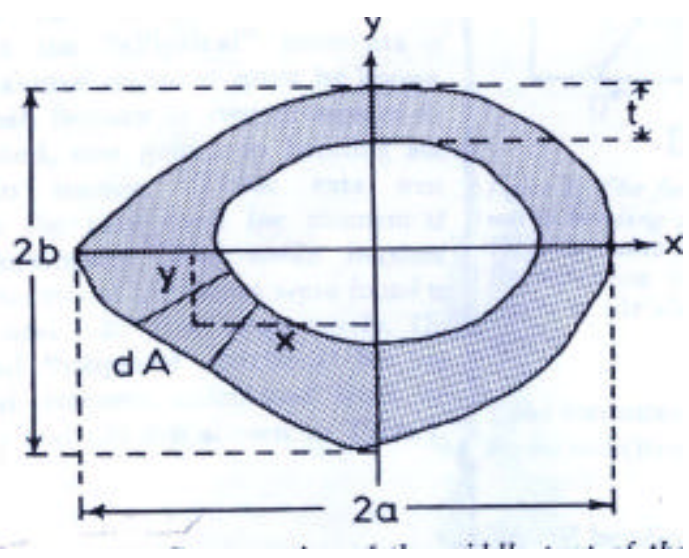

Figure 2.3-2: Cross sectional area of the middle part of the tibia or femur (Engesaeter, Ekeland et al. 1978). 
The bending stress was found using the follow equation

$$
\sigma=\frac{M \cdot b}{I}
$$

where, the follow equation was used to find the area moment of inertia

$$
I=\pi \cdot\left(a b^{3}-(a-t)(b-t)^{3}\right)
$$

Where the major axis $a$ and minor axis $b$ along with the thickness in 4 places shown in figure $2.3-2$. In a study done by Engesaeter it was found that if bone is estimated hollow ellipse that there is $11 \%$ error in the area moment of inertia and $2 \%$ in polar moment of inertia (Engesaeter, Ekeland et al. 1978).

Three point bending test uses the right femur. First the outside area and length was measured. The MTS machine will be used to apply a load in the center of the femur. The unsupported length is $62 \mathrm{~mm}$. The loading rate was $3 \mathrm{~mm} / \mathrm{min}$ (Akhter, Iwaniec et al. 2003). The bone was loaded till failure, while the force and displacement data were collected.

\subsection{Introduction to Femoral Neck Testing}

The femoral neck is common area for fractures in osteoporoistic patients. As stated earlier, one out of eight hip fracture in women are attributed to smoking, according to Law (Law and Hackshaw 1997). This test is done to test the strength for femoral neck to see if there are any structural changes in the bone due to nicotine. Rabbit femurs are quite different from human femur, but they are still testable.

Femoral neck fracture test used the right femur. First, the distal end will be cut off at the middle of the femur. Next the specimen will be plotted in Corallite Doz-all, and then re-hydrated for an hour. The MTS will be used to test the specimen with 
loading rate of $4.91 \mathrm{~mm} / 200 \mathrm{~s}$. The load will be applied on the femoral head as shown in figure $2.3-1$. The load is applied in Newtons, and the data will be collected in the same way the fracture toughness was.

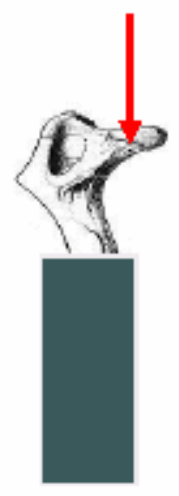

Figure 2.4-1: Location of where the load is applied for the femoral neck test (Smith 2003)

\subsection{Introduction to Torsion test}

The Torsion test was done to see if nicotine had any effect on shear stress. Ueng (Ueng, Lee et al. 1997) used the torsion test on rabbit tibia to see if smoking affected bone healing of the tibia. This test measures (figure $2.5-1$ ) the amount of torque it takes for each bone to break, the angle at which it will break, and the amount of shear stress in each bone. 


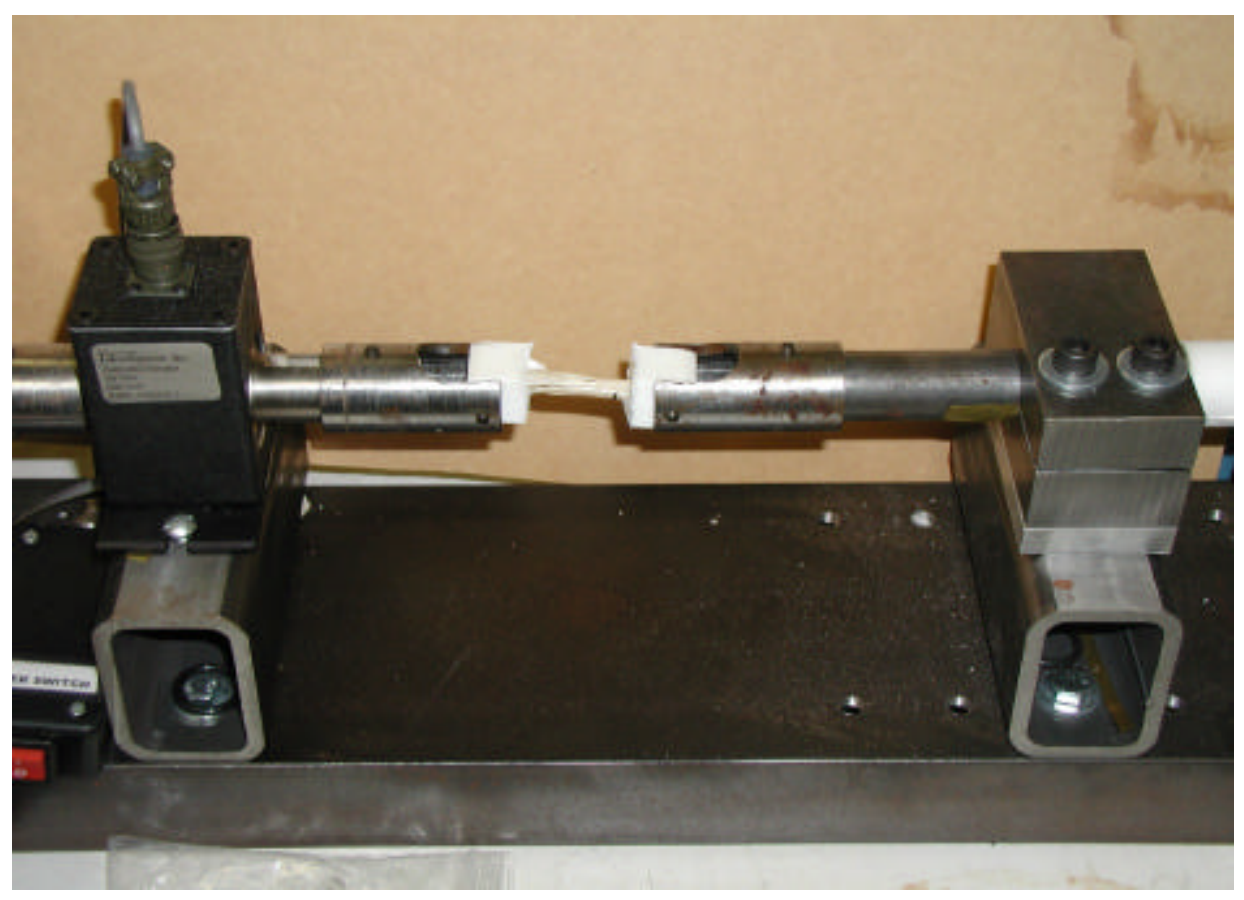

Figure 2.5-1: Torsion Test set up

Once the polar moment of inertia was found the shear stress could be found using the equation

$$
\tau=\frac{T \cdot b}{I_{P}}
$$

where the polar moment of inertia the following equation was used.

$$
I_{P}=\pi\left(a b^{3}+a^{3} b-(a-t)(b-t)^{3}-(a-t)^{3}(b-t)\right)
$$

The left tibia was used in the torsion test. First, the proximal end has been cut off perpendicular to the axis. Next each specimen was plotted in Corallite Doz-all. Then after specimens dried they were placed in saline for an hour to re-hydrate. Before each test the outside area, and the unsupported length was measured using a caliber. Finally the specimen was placed in the torsion testing device made by Vincent Kish, tested at a rate of 1 degree per second (Cain 2003). The data was collected in the same manner as the fracture toughness test. 


\section{Chapter 3 Histomorphometry and Composition \\ 3.1 In troduction to Histomorphometry}

Histology is the study of anatomy that deals with the minute structure of animals

and plants by using a microscope. Lexicon is the abbreviations of words commonly used histomorphometric measurements of bone. An example is osteon area, which is, OnAr. This abbreviation has became standardized by Parfitt (Parfitt, Drezner et al. 1987). This help when reporting measurements by abbreviations to reduce the size and ease of the report. In table $3.1-1$ is an example of Lexicon abbreviations. 
Table 3.1 - 1: Lexicon abbreviations (Parfitt, Drezner et al. 1987)

\begin{tabular}{|c|c|c|c|}
\hline $\mathrm{A}$ & Apposition(al) & $\mathrm{m}$ & Maturation \\
\hline $\mathrm{Ab}$ & Absolute & $\mathrm{N}$ & Number of profiles or structures \\
\hline Ac & Activation & $\mathrm{n}$ & Number of sampling units \\
\hline $\mathrm{Aj}$ & Adjusted & $\mathrm{O}$ & Osteoid \\
\hline $\mathrm{Ar}$ & Area (2D) & $\mathrm{Ob}$ & Osteoblast(ic) \\
\hline a & $\operatorname{Activ}(e)(i t y)$ & $\mathrm{Oc}$ & Osteoclast(ic) \\
\hline B & Bone & On & Osteon(al) \\
\hline $\mathrm{BMU}$ & Basic Multicellular Unit & $\mathrm{Ot}$ & Osteocyt(e)(ic) \\
\hline $\mathrm{Ca}$ & Canal(icula)(r) & $\mathrm{P}$ & Period \\
\hline $\mathrm{Cd}$ & Corrected & Pm & Perimeter (2D) \\
\hline $\mathrm{Cn}$ & Cancellous & Po & Por(e)(ous)(osity) \\
\hline $\mathrm{Ct}$ & Cortical & Ps & Periost(eal)(eum) \\
\hline$d$ & Double & $\mathrm{Pt}$ & Point \\
\hline $\mathrm{E}$ & Ero(ded)(sion) & Q & Quiescent \\
\hline EX & External & $\mathrm{R}$ & Rate \\
\hline $\mathrm{F}$ & Formation & $\mathrm{Rd}$ & Radi(al)(us) \\
\hline $\mathrm{Fb}$ & Fibro(sis)(us) & Rf & $\operatorname{Referen}(c e)(t)$ \\
\hline $\mathrm{Fr}$ & Front & $\mathrm{Rm}$ & Remodeling \\
\hline $\mathrm{f}$ & Frequency & Rs & Resorption \\
\hline $\mathrm{G}$ & Grow(th)(ing) & $\mathrm{S}$ & Surface (3D) \\
\hline $\mathrm{H}$ & Haversian & $\mathrm{Sa}$ & Sample \\
\hline $\mathrm{Hp}$ & Hypertrophic & $\mathrm{Se}$ & Section \\
\hline $\mathrm{Ht}$ & Height & $\mathrm{Sn}$ & Spongiosa \\
\hline $\mathrm{Hz}$ & Horizontal & St & Structur(e)(al) \\
\hline I & Interface (3D) & $\mathrm{s}$ & Single \\
\hline Ic & Intercept & $\mathrm{Tb}$ & Trabecula(r) \\
\hline Il & Initial & $\mathrm{Th}$ & Thickness (3D) \\
\hline In & Internal & $\mathrm{Tt}$ & Total \\
\hline Ir & Inter & $\mathrm{t}$ & Time \\
\hline $\mathrm{i}$ & Intersection & $\mathrm{U}$ & Unit \\
\hline $\mathrm{L}$ & Label(led) & $\mathrm{V}$ & Volume (3D) \\
\hline $\mathrm{Lc}$ & Lacuna(r) & $\mathrm{Vd}$ & Void \\
\hline $\mathrm{Le}$ & Length & $\mathrm{Vk}$ & Volkmanns \\
\hline $\mathrm{Lm}$ & Lamella(r) & $\mathrm{Vt}$ & Vertical \\
\hline $\mathrm{Ln}$ & Line & W & Wall \\
\hline Lo & Longitudinal & $\mathrm{Wi}$ & Width \\
\hline 1 & lag & Wo & Woven \\
\hline M & Mineral(iz)(ing)(ation) & $\mathrm{Z}$ & Zone \\
\hline $\mathrm{Me}$ & Medullary & & \\
\hline Ml & Modeling & & \\
\hline
\end{tabular}




\subsection{Static Histomorphometry}

Static histomorphometry is the microscopic measurement of the surface and structure. A number of measurements will be taken. The reason we look at the bone microstructure is because it is usually where changes occur first as the most sensitive measure of bone alteration. These measurements are static because the bone is not living and a slide is snapshot of what was happening to the bone at the time of death. These measurements have been done in terms of the total area viewed. Some important measurements are listed below.

\section{Total area (TtAR)}

Is the total area of the image. This measurement is used for many of the other measurements made.

\section{Porosity (Po)}

The pores in the bone, which are darker, then the bone matrix where measured under the microscope (figure $3.2-1$ ). These pores are haversian, and volkmann canals, and any other space in the bone. This area is then divide by the total area measured.

$$
P o=\frac{H n \cdot C n \cdot A r+V \cdot C n \cdot A r+\operatorname{Pr} \cdot P o \cdot A r}{T t \cdot A r}
$$




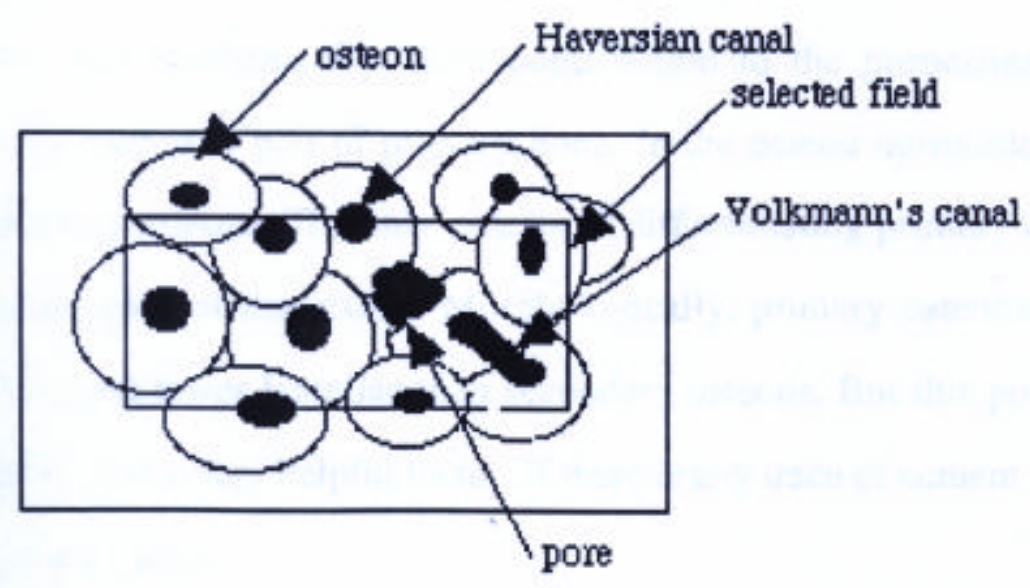

Figure 3.2 -1: Example Porosity Measurements (Wang 1995)

\section{Average Pore Radius (AvPoRd)}

The haverisan canals are most circular in shape and this equation finds the average radius of each haverisan canal.

$$
\text { AvPoRd }=\operatorname{sqrt}(\text { Haverisan Canals Area/(\# of Haverisan Canals PI }()))
$$

\subsection{Histomorphometric Analysis}

To perform static histological analysis, it is bone cross section need to be stained and mounted on slides for microscope viewing. Because bone is fragile material, it cannot be cut to thin slices by it self, and therefore is needs to be embedded in plastic (Section 3.3.1). Once in embedded the specimens have been cut on the diamond wire saw to about $100 \mu \mathrm{m}$. After the specimen has been sliced it then is polished to remove any scratches (Section 3.3.2) (Wang 1995). After the specimen has been polished it will need to be stained (Section 3.3.3). Once this has been done histology measurements of the specimen were conducted. 


\subsubsection{Embedding Procedure}

1. Specimen are placed in $10 \%$ neutral buffered formalin for about a week

2. The specimen are placed in hypercenter XP tissue processor (Shandon, Pittburgh, PA) for processing which includes:
a. Dehydration in alcohol
b. Clearing with Xylene
c. Inflitration with methymethacrylate (MMA)

3. Specimens are embedded in MMA (100 ml MMA to .2 g Perkadox $)$

4. Specimen are left in a vacuum oven for 1-2 hours to remove air bubbles

5. Specimen are placed in water bath $\left(36^{\circ} \mathrm{C}\right)$ overnight for polymerization 


\subsection{2 polishing procedure}

1. Cut Sections From Plastic Embedded Bone. Make the cuts at 45 marks $(450 \mu \mathrm{m})$, which will give a final thickness of $100 \mu \mathrm{m}$.

2. Store the sections in plastic cassettes labeled with the specimen number in a large beaker of distilled water.

3. Use forceps to pick up the specimen and gently place on the $800 \#$ sandpaper. Spray a small puddle of distilled on the sand paper. Begin polishing circular motion, add some pressure. Keep polishing for four mins. Turn over three times (1 min $20 \mathrm{sec}$ per side).

4. Put the specimen on the nylon cloth. Spray 2-3 drops of 3 micron polishing solution (green) on the cloth. Polish using circular motion. Polish for 6 minutes, turning three times (every 2 mins).

5. Put the specimen on the second nylon cloth. Spray 2-3 drops of 1 micron polishing solution (blue) on the cloth. Polish with circular motions. Polish for 4 minutes. Turn over three times (1min $20 \mathrm{sec}$ per side).

6. Put the specimen on the microcloth, spray with a few drops of distilled water. Polish with circular motions for 2 mins., turning over once (1 min per side).

7. Dry the specimen on a napkin for approximately five minutes. Check on the microscope $40 x$ to make sure there are no scratches. If there are scratches repeat steps three through five. If there are not scratches mount on a slide labeled with the specimen number with flourmount and cover slip. If it is to be stained, place the specimen back in the cassette and store in a small beaker of distilled water. 


\subsubsection{Staining Procedure}

Protocol was used for staining of the bone slices. First the section was placed into a container, then the section is rinsed in water and is placed in Harris' Hematoxylin for 15 minutes at $95 \mathrm{rpm}$ on platform shaker. After the 15 minutes in the platform shaker the specimen is placed in running water for 5 minutes, in which it is then dipped in to acid alcohol for 20 dips, then it is placed in running water again for 8 minutes. The specimen is then dipped into ammonia water for 15 dips. Again it is placed in running water for 15 mins. After that it is placed in eosin for 6 minutes then is dipped in $80 \%$ alcohol for 10 dips, then 95\% alcohol, 100\% alcohol, 100\% alcohol, and Xylene for 15 dips. Once this is done the specimen is removed from the container and is placed on a slide and is covered and left to set for the night.

\subsection{Compositions}

This is the procedure used to measure the compositions of bone.

1. Take dimensions of the specimens and calculate their volume

2. Weigh and record crucible weights

3. Hydrate specimens overnight in saline

4. Blot specimens dry, weigh and record wet weights of the specimens.

5. Defat specimen by placing them in acetone and agitating overnight (platform shaker at $160 \mathrm{rpm})$

6. Weigh and record defatted weight 
7. Place in vacuum oven, containing desiccant at $60^{\circ} \mathrm{C} \mathrm{(2.2)} \mathrm{and} 20$ psi vacuum pressure overnight. Remove and place in desiccator for one hour to permit return to room temperature.

8. Repeat step 8 until a constant weight is obtained.

9. Place specimen in crucible and ash in muffle furnace at $600^{\circ} \mathrm{C}(60$ on the dial High) for 24 hours.

10. Remove specimen from furnace. Place in desiccator until room temperature is attained (1 hour). Weight and record weight of crucible and ashed specimen.

Equations used

$$
\begin{aligned}
& \text { Wet Density }=\text { WW/V } \\
& \text { Dry Density }=\mathrm{DW} / \mathrm{V} \\
& \% \text { Mineral, \%Min }=(\mathrm{AW} / \mathrm{DW}) * 100 \\
& \% \text { Organic }(\mathrm{Wet})=[(\mathrm{DW}-\mathrm{AW}) / \mathrm{WW}] * 100 \\
& \% \text { Organic }(\text { Dry })=[(\mathrm{DW}-\mathrm{AW}) / \mathrm{DW}] * 100 \\
& \% \mathrm{Ash}=(\mathrm{AW} / \mathrm{WW}) * 100 \\
& \% \mathrm{H}_{2} \mathrm{O}=[(\mathrm{WW}-\mathrm{DW}) / \mathrm{WW}] * 100
\end{aligned}
$$

\section{Chapter 4 Statistical Methods}

Statistical comparison between groups was done by JMP (version 3.2.1 SAS Institute, Inc, Cary, NC). Significance was tested using ANOVA, student t-test, and Tukey-Kramer HSD. Statistical significance was set p<.05 (95\%). 


\section{Chapter 5 Results}

\subsection{Nicotine serum levels and Weight for Experiment 1}

All individual rabbit data for each test is in Appendix A for Group 1.

Terminology for Results

Average Nicotine serum level is the average of measurement of the nicotine level measure during weeks the 1,3 and 5 .

Weight Difference is the measured final weight minus the starting weight, which is the weight measurement right after the surgery.

Figure 5.1 - 1 is average nicotine level seen during the 5-week period after surgery for each group, and table $5.1-1$ is the values for figure $5.1-1$ and the $p$ values for each group. Figures and table $5.1-2 \& 3$ are for weight and nicotine level over the 5-week period for each group. Figure $5.1-4 \& 5$ are for weight difference versus nicotine level during the 5 weeks. 


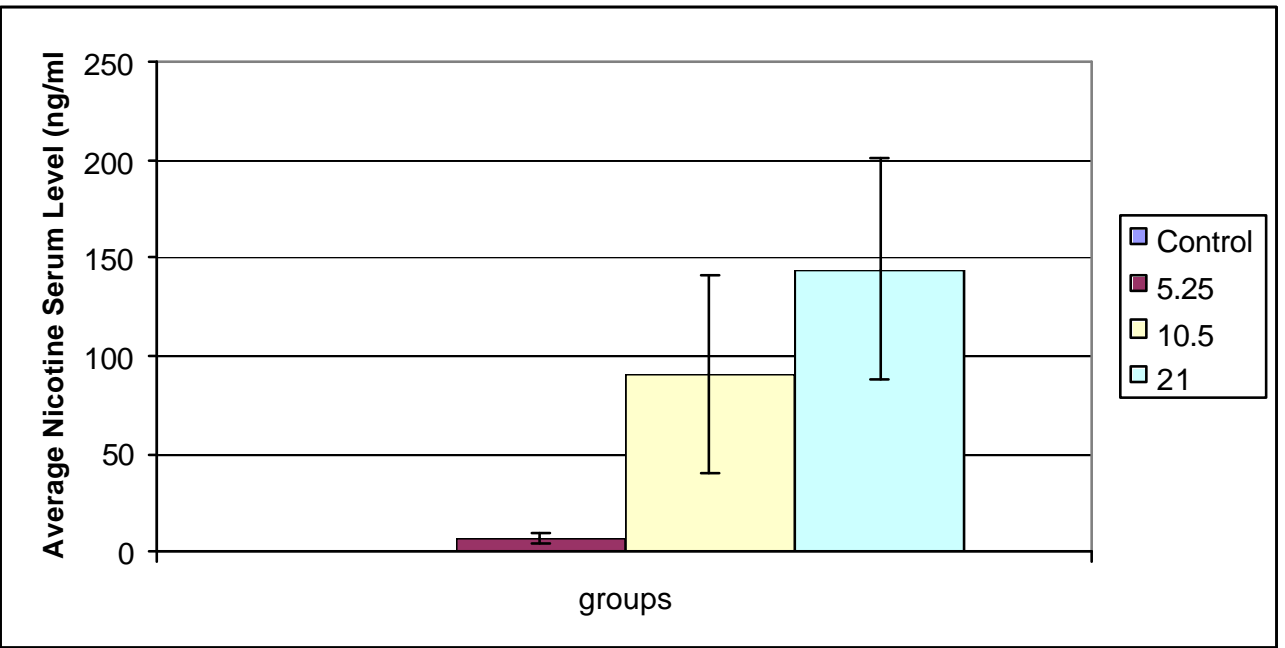

Figure 5.1 -1: Average nicotine level for each group

Table 5.1 - 1: Values for figure 5.1-1 and $p$ values for each group

\begin{tabular}{|c|c|c|c|c|}
\hline Group & Nicotine Level (ng/ml) & Standard Deviation & groups & P values \\
\hline Control & 0 & 0 & All & 0.0004 \\
\hline 5.25 & 7.45 & 2.549437 & all & 0.0794 \\
\hline 10.5 & 90.68 & 50.81941 & $5.25 \& C$ & 0.1787 \\
\hline \multirow[t]{4}{*}{21} & 143.9833 & 56.39678 & $10.5 \& C$ & 0.0645 \\
\hline & & & $21 \& C$ & 0.0145 \\
\hline & & & $5.25 \& 21$ & 0.0015 \\
\hline & & & $10.5 \& 21$ & 0.1374 \\
\hline
\end{tabular}




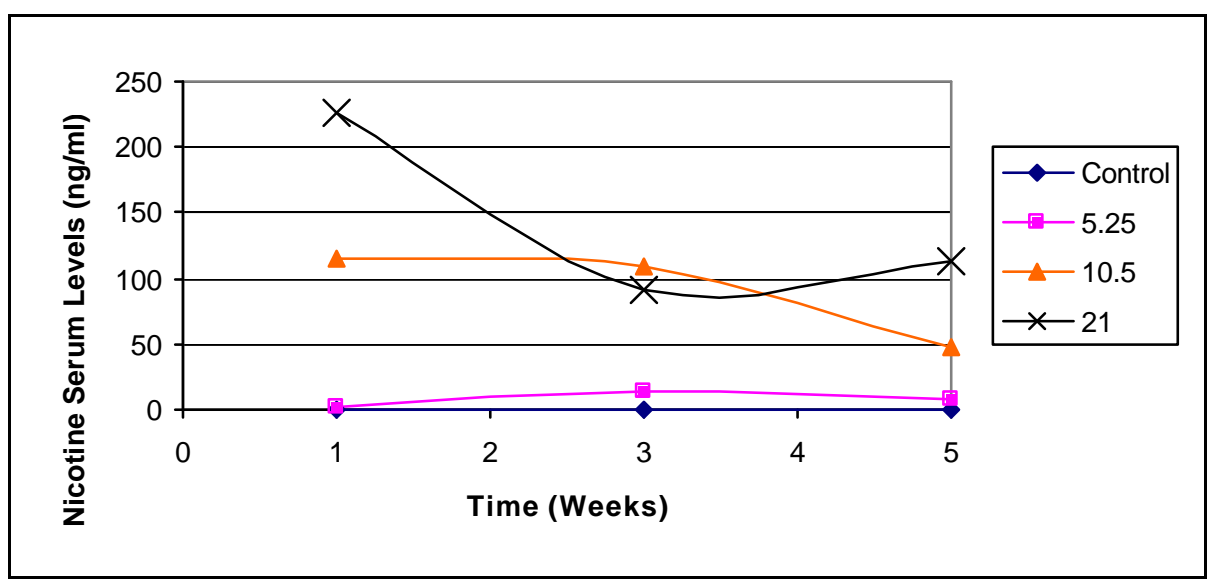

Figure 5.1 - 2: Nicotine levels during the 5 weeks period

Table 5.1 - 2: Values for figure 5.1 - 2

\begin{tabular}{|r|l|l|l|}
\hline Group & $\begin{array}{l}\text { Week 1 Nicotine } \\
\text { Level (ng/ml) }\end{array}$ & $\begin{array}{l}\text { Week 3 Nicotine } \\
\text { Level (ng/ml) }\end{array}$ & $\begin{array}{l}\text { Week 5 Nicotine } \\
\text { Level }(\mathbf{n g} / \mathbf{m l})\end{array}$ \\
\hline Control & 0 & 0 & 0 \\
\hline 5 & 1.75 & 13.475 & 7.125 \\
\hline 10.5 & 115.44 & 109.2 & 47.4 \\
\hline 21 & 227 & 91.45 & 113.5 \\
\hline
\end{tabular}




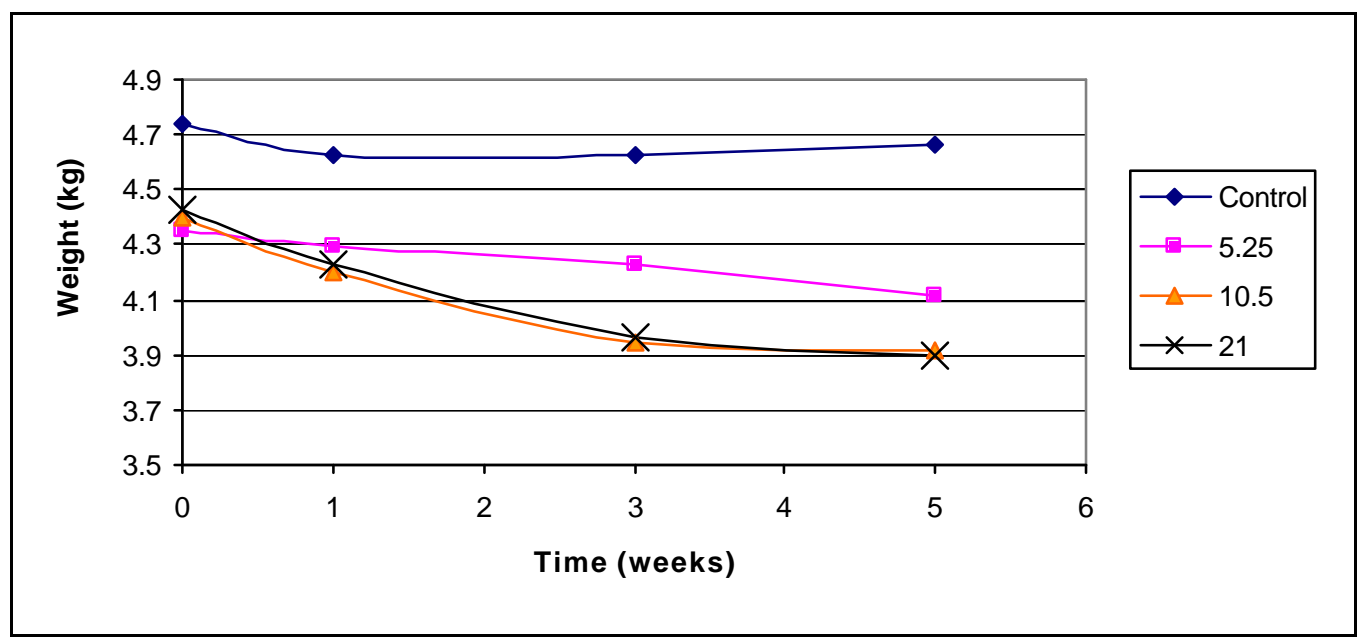

Figure 5.1 - 3: Average Weight of the rabbits during the 5-week period

Table 5.1 - 3: values for figure 5.1 - 3

\begin{tabular}{|r|r|r|l|r}
\hline Group & $\begin{array}{l}\text { Starting } \\
\text { Weight } \mathbf{( k g )}\end{array}$ & $\begin{array}{l}\text { Week 1 } \\
\text { Weight } \mathbf{( k g )}\end{array}$ & $\begin{array}{l}\text { Week 3 } \\
\text { Weight } \\
\text { (kq) }\end{array}$ & $\begin{array}{l}\text { Week 5 } \\
\text { Weight (kg) }\end{array}$ \\
\hline Control & 4.743333 & 4.63 & 4.63 & 4.666667 \\
\hline 5 & 4.3525 & 4.2925 & 4.225 & 4.1125 \\
\hline 10.5 & 4.398 & 4.198 & 3.944 & 3.912 \\
\hline 21 & 4.43 & 4.225 & 3.963333 & 3.898333 \\
\hline Group & $\begin{array}{l}\text { Standard } \\
\text { Deviation }\end{array}$ & $\begin{array}{l}\text { Standard } \\
\text { Deviation }\end{array}$ & $\begin{array}{l}\text { Standard } \\
\text { Deviation }\end{array}$ & $\begin{array}{l}\text { Standard } \\
\text { Deviation }\end{array}$ \\
\hline Control & 0.127017 & & 0 & 0.247049 \\
\hline 5 & 0.339252 & 0.39424 & 0.413642 & 0.443199 \\
\hline 10.5 & 0.184716 & 0.213588 & 0.390167 & 0.35968 \\
\hline 21 & 0.275536 & 0.335067 & 0.34691 & 0.294239 \\
\hline
\end{tabular}




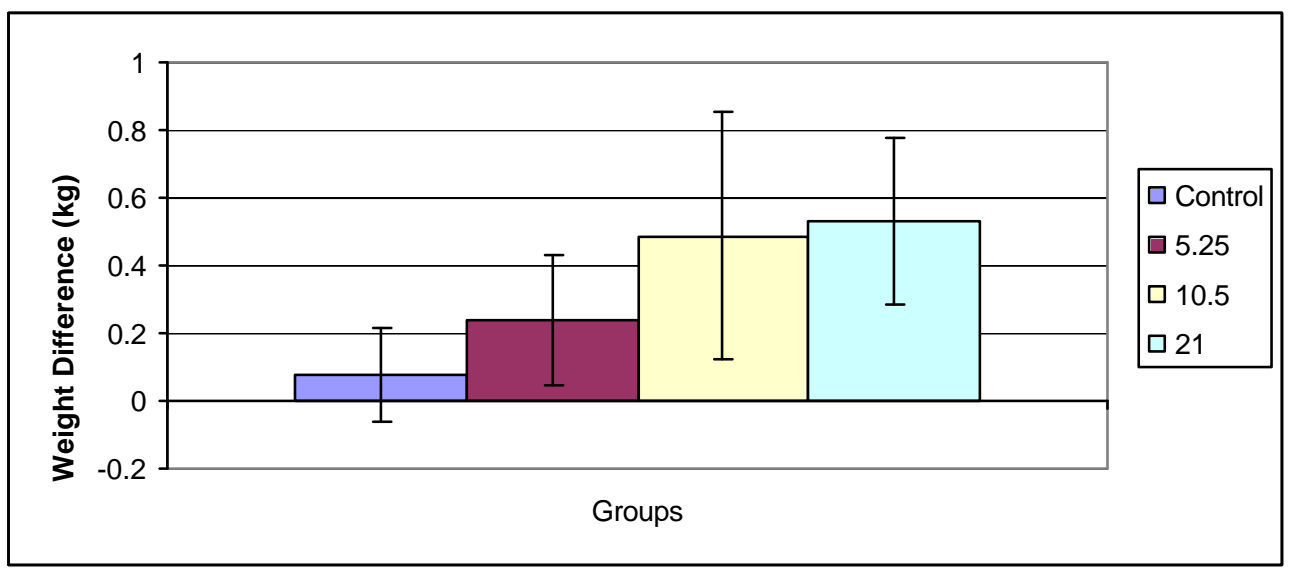

Figure 5.1 - 4: Weight difference for each group

Table 5.1 - 4: Values for figures 5.1 - 4 and $p$ values for each group

\begin{tabular}{|r|r|r|}
\hline Groups & Weight difference & $\begin{array}{r}\text { Standard } \\
\text { Deviation }\end{array}$ \\
\hline Control & 0.076667 & 0.138684 \\
\hline 5.25 & 0.24 & 0.191311 \\
\hline 10.5 & 0.486 & 0.365828 \\
\hline 21 & 0.531667 & 0.243509 \\
\hline
\end{tabular}

\begin{tabular}{|l|r|}
\hline Groups & Prob $>\mathbf{F}$ \\
\hline all & 0.0924 \\
\hline $5.25 \&$ C & 0.2694 \\
\hline $10.5 \&$ C & 0.1199 \\
\hline $21 \&$ C & 0.0217 \\
\hline $5.25 \& 10.5$ & 0.2663 \\
\hline $5.25 \& 21$ & 0.0799 \\
\hline $10.5 \& 21$ & 0.8096 \\
\hline
\end{tabular}

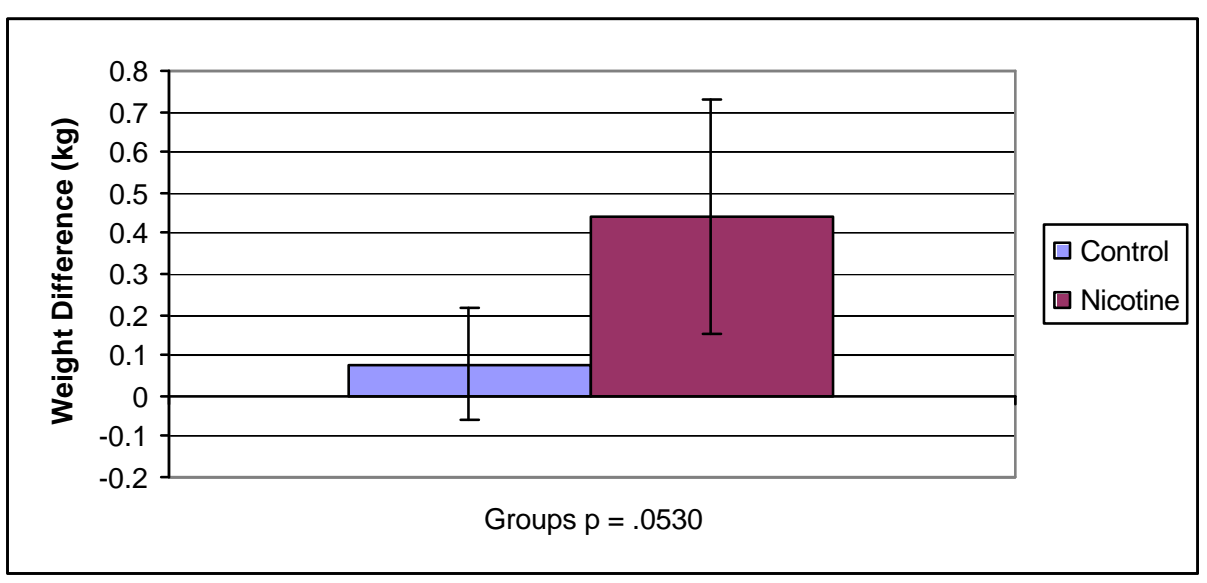

Figure 5.1 - 5: Weight Difference for control and nicotine groups as a whole

Table 5.1 - 5: Values for figure 5.1 - 5

\begin{tabular}{|l|r|r|}
\hline Groups & weight difference & Standard Deviation \\
\hline Control & 0.076667 & 0.138684 \\
\hline Nicotine & 0.438667 & 0.288168 \\
\hline
\end{tabular}




\subsection{Fracture Toughness Testing for Experiment 1}

Figure $5.2-1$ is fracture toughness values for each group and table $5.2-1$ is the values for figure 5.2 - 1 along with the $\mathrm{p}$ values for each group. Figure 5.2 -2 and table 5.2 is fracture toughness values as consider the nicotine and controls group as a whole.

Table $5.2-3$ is the dimensions for fracture toughness specimens groups.

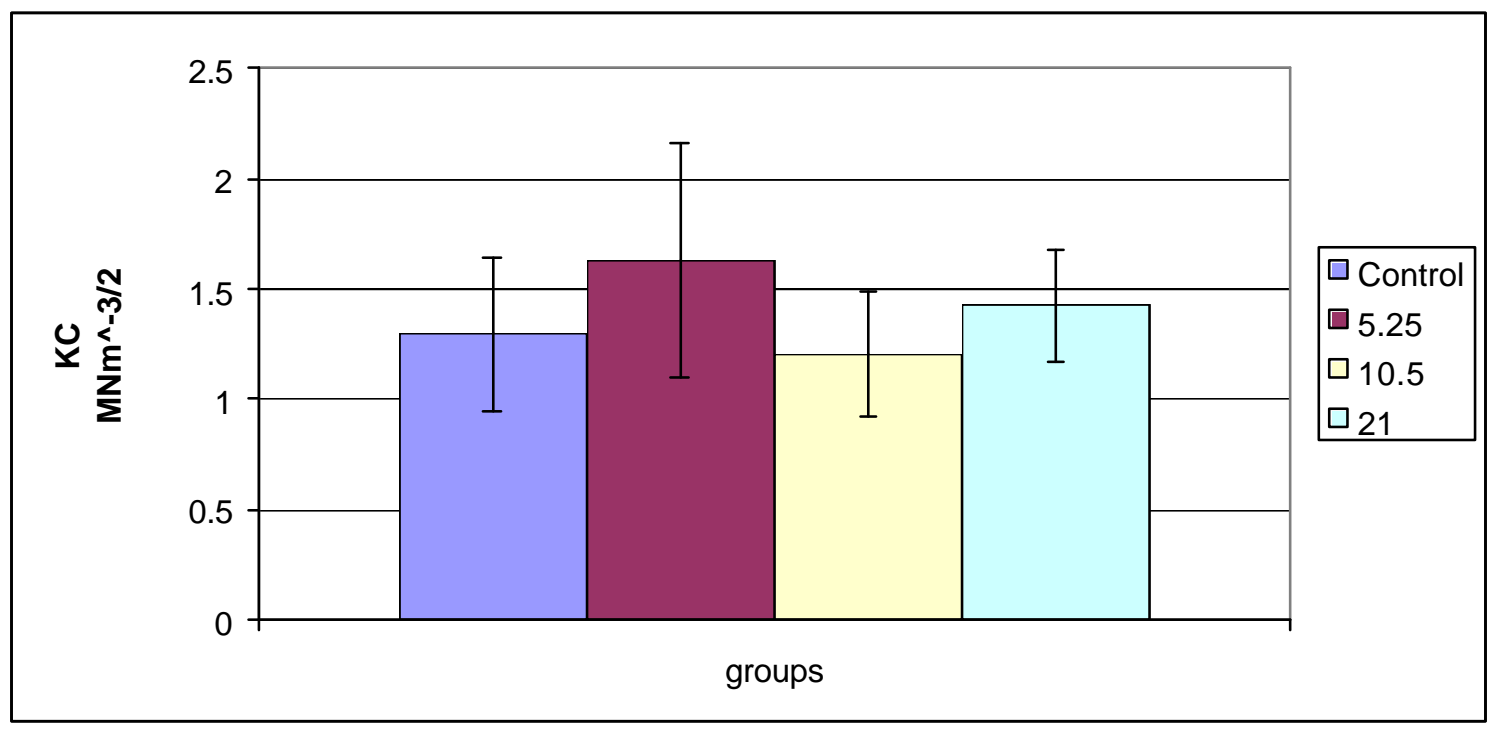

Figure 5.2 - 1: Fracture toughness values for each group

Table 5.2 - 1: Value for figure 5.2 -1 and $p$ value for each group

\begin{tabular}{|r|r|r|}
\hline $\begin{array}{l}\text { Nicotine } \\
\text { groups }\end{array}$ & $\begin{array}{l}\text { Fracture } \\
\text { Toughness } \\
(\text { MNm^-3/2) }\end{array}$ & $\begin{array}{l}\text { Standard } \\
\text { Deviation }\end{array}$ \\
\hline Control & 1.294559 & 0.346752 \\
\hline 5.25 & 1.63341 & 0.529539 \\
\hline 10.5 & 1.206556 & 0.281598 \\
\hline 21 & 1.425818 & 0.25425 \\
\hline
\end{tabular}

\begin{tabular}{|l|r|}
\hline Groups & Prob $>F$ \\
\hline all & 0.3483 \\
\hline $5.25 \&$ C & 0.384 \\
\hline $10.5 \&$ C & 0.7063 \\
\hline $21 \&$ C & 0.5339 \\
\hline $5.25 \& 10.5$ & 0.1618 \\
\hline $5.25 \& 21$ & 0.4237 \\
\hline $10.5 \& 21$ & 0.2077 \\
\hline
\end{tabular}




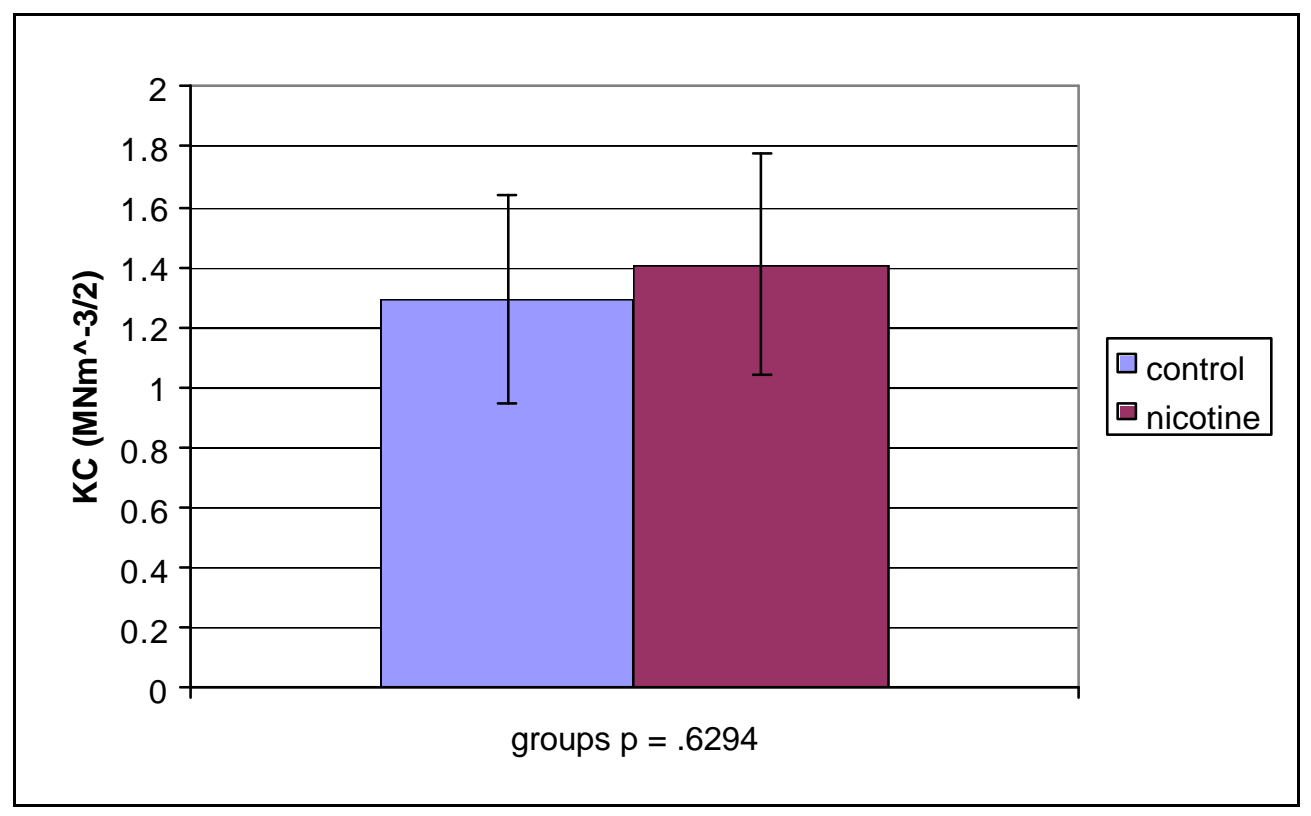

Figure 5.2 - 2: Fracture toughness of nicotine and control groups as a whole

Table 5.2-2: Value for figure 5.2 - 2

\begin{tabular}{|l|r|r|}
\hline $\begin{array}{l}\text { Nicotine } \\
\text { groups }\end{array}$ & $\begin{array}{l}\text { Fracuture } \\
\text { Toughness } \\
\left(\mathbf{M N m}^{\wedge} \mathbf{- 3 / 2}\right)\end{array}$ & $\begin{array}{l}\text { Standard } \\
\text { Deviation }\end{array}$ \\
\hline control & 1.294559 & 0.346752 \\
\hline nicotine & 1.408088 & 0.367393 \\
\hline
\end{tabular}

Table 5.2 - 3: Dimension for fracture toughness specimens groups

\begin{tabular}{|r|r|r|r|r|r|}
\hline group & \multicolumn{1}{|l|}{ thickness } & \multicolumn{1}{l|}{$\mathbf{l}$} & W & a/W & \multicolumn{1}{l|}{ load } \\
\hline Control & 0.000617 & 0.0027 & 0.005203 & 0.518473 & 5.560433 \\
\hline 5.25 & 0.000533 & 0.002598 & 0.005299 & 0.491512 & 7.084 \\
\hline 10.5 & 0.000604 & 0.002508 & 0.005147 & 0.487858 & 5.74026 \\
\hline 21 & 0.000588 & 0.002592 & 0.005366 & 0.482685 & 6.757855 \\
\hline group & $\begin{array}{l}\text { Standard } \\
\text { Deviation }\end{array}$ & $\begin{array}{l}\text { Standard } \\
\text { Deviation }\end{array}$ & $\begin{array}{l}\text { Standard } \\
\text { Deviation }\end{array}$ & $\begin{array}{l}\text { Standard } \\
\text { Deviation }\end{array}$ & $\begin{array}{l}\text { Standard } \\
\text { Deviation }\end{array}$ \\
\hline Control & 0.000087 & 0.000303 & 0.000191 & 0.047365 & 1.337118 \\
\hline 5.25 & 0.000043 & 0.000161 & 0.000219 & 0.048047 & 3.324273 \\
\hline 10.5 & 0.00009 & 0.000377 & 0.00034 & 0.075883 & 1.874261 \\
\hline 21 & 0.000099 & 0.000219 & 0.000343 & 0.019239 & 1.894408 \\
\hline
\end{tabular}




\subsection{3-Point Bending Testing for Experiment 1}

Figure 5.3 - 1 and table 5.3 - 1 are the bending stress for each group along with the values and $p$ values for each group. Figure 5.3 - 2 and table $5.3-2$ are bending stress values for nicotine and control groups as a whole.

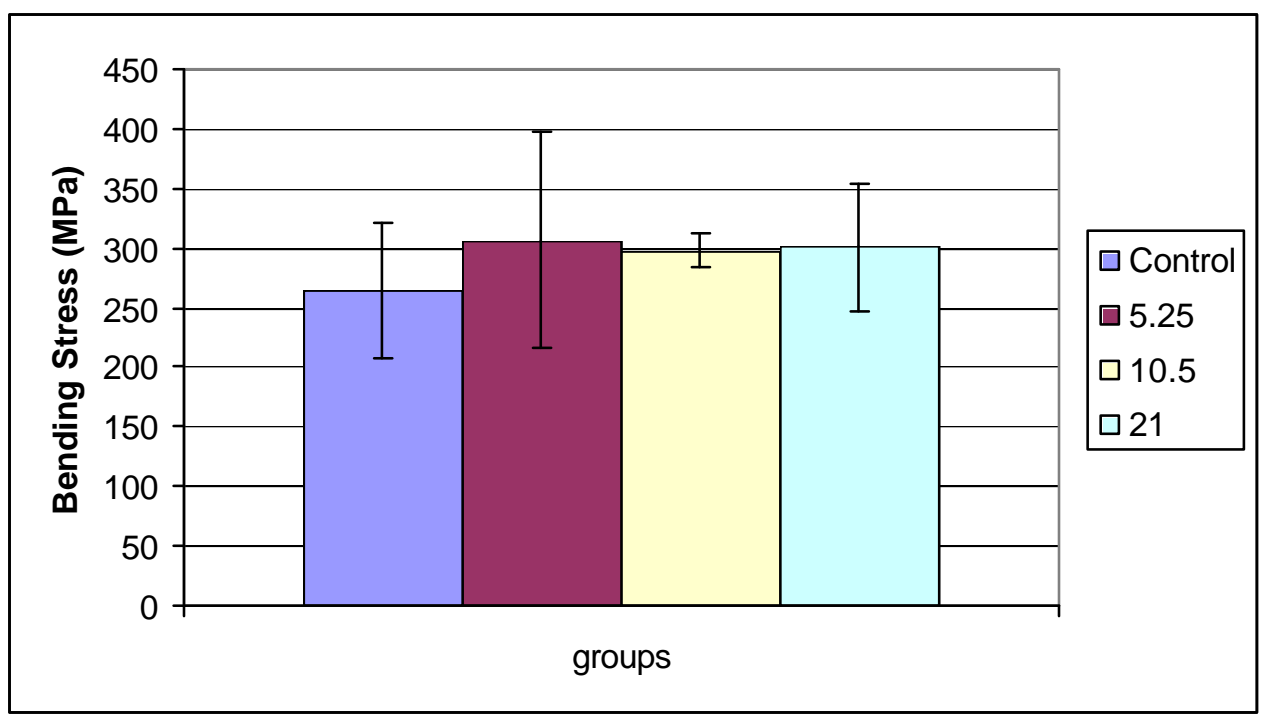

Figure 5.3 - 1: Average Bending Stress for each group

Table 5.3-1: Values for figure 5.3-1 and $p$ value for each group

\begin{tabular}{|r|r|r|}
\hline groups & $\begin{array}{l}\text { Bending Stress } \\
\text { (MPa) }\end{array}$ & $\begin{array}{l}\text { Standard } \\
\text { Deviations }\end{array}$ \\
\hline Control & 264.5452 & 57.44951 \\
\hline 5.25 & 306.9135 & 89.84725 \\
\hline 10.5 & 297.6781 & 14.39813 \\
\hline 21 & 300.7559 & 53.99466 \\
\hline
\end{tabular}

\begin{tabular}{|l|r|}
\hline groups & p values \\
\hline All & 0.7816 \\
\hline $5.25 \&$ C & 0.5114 \\
\hline $10.5 \&$ C & 0.2448 \\
\hline $21 \&$ C & 0.3828 \\
\hline $5.25 \& 10.5$ & 0.8246 \\
\hline $5.25 \& 21$ & 0.8944 \\
\hline $10.5 \& 21$ & 0.9049 \\
\hline
\end{tabular}




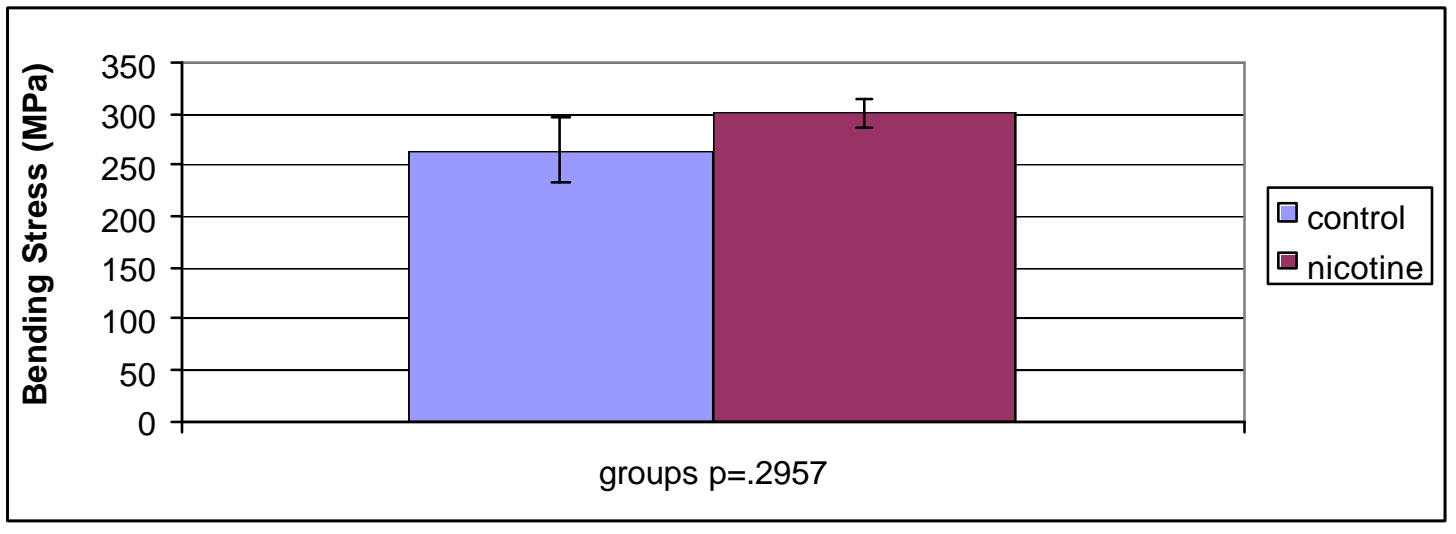

Figure 5.3 -2: Bending Stress for Nicotine and control group as a whole

Table 5.3 - 2: Values for figure 5.3 -2

\begin{tabular}{|l|r|r|}
\hline groups & Bending Stress (Mpa) & Standard Devation \\
\hline control & 264.545 & 31.097 \\
\hline nicotine & 301.372 & 13.907 \\
\hline
\end{tabular}




\subsection{Femoral Neck Testing for Experiment 1}

Figure 5.4-1 and table 5.4-1 are for femoral neck load along with the value and $\mathrm{p}$ values for each group. Figure 5.4-2 and table 5.4-2 is the femoral neck load for nicotine and control groups as a whole

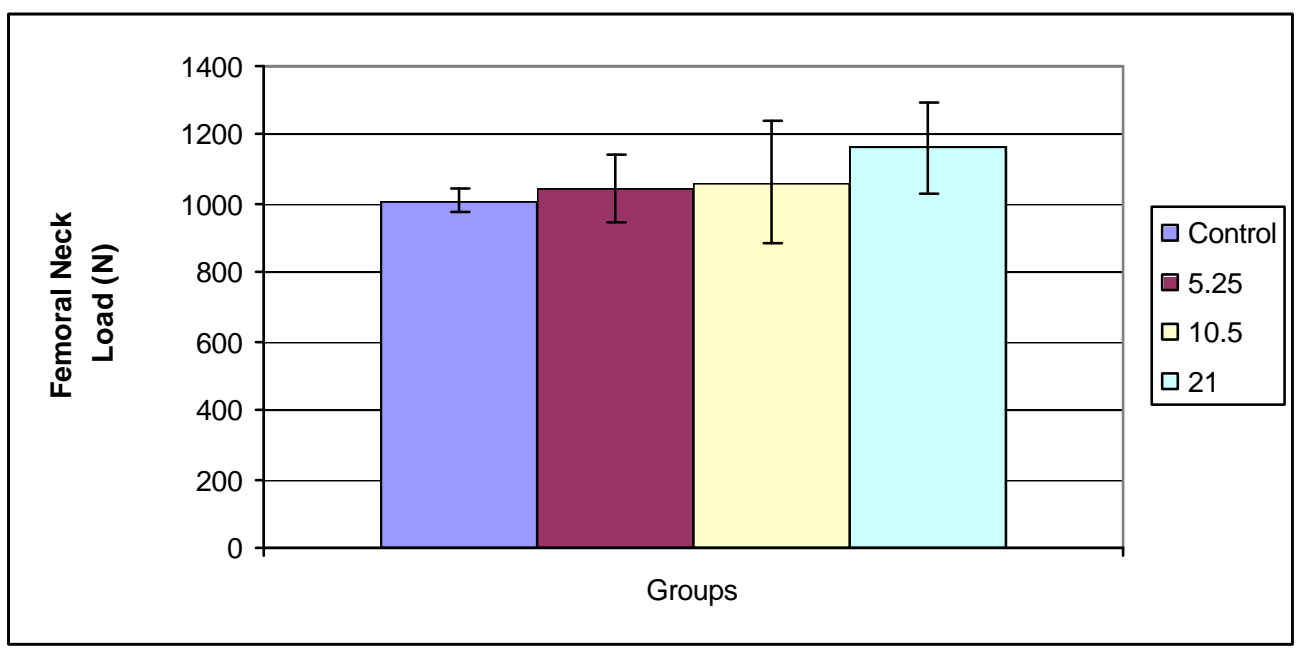

Figure 5.4 - 1: Femoral Neck Load for each group

Table 5.4-1: Values for figure 5.4- 1 and $p$ values for each group

\begin{tabular}{|r|r|r|}
\hline Groups & $\begin{array}{l}\text { Femoral Neck load } \\
(\mathbf{N})\end{array}$ & $\begin{array}{l}\text { Standard } \\
\text { Deviation }\end{array}$ \\
\hline Control & 1007.286 & 33.55777 \\
\hline 5.25 & 1043.511 & 97.31283 \\
\hline 10.5 & 1061.407 & 179.7679 \\
\hline 21 & 1165.185 & 132.3397 \\
\hline
\end{tabular}

\begin{tabular}{|l|r|}
\hline Groups & Prob $>$ F \\
\hline all & 0.3292 \\
\hline $5.25 \&$ C & 0.5712 \\
\hline $10.5 \&$ C & 0.6345 \\
\hline $21 \&$ C & 0.0893 \\
\hline $5.25 \& 10.5$ & 0.864 \\
\hline $5.25 \& 21$ & 0.1561 \\
\hline $10.5 \& 21$ & 0.2982 \\
\hline
\end{tabular}




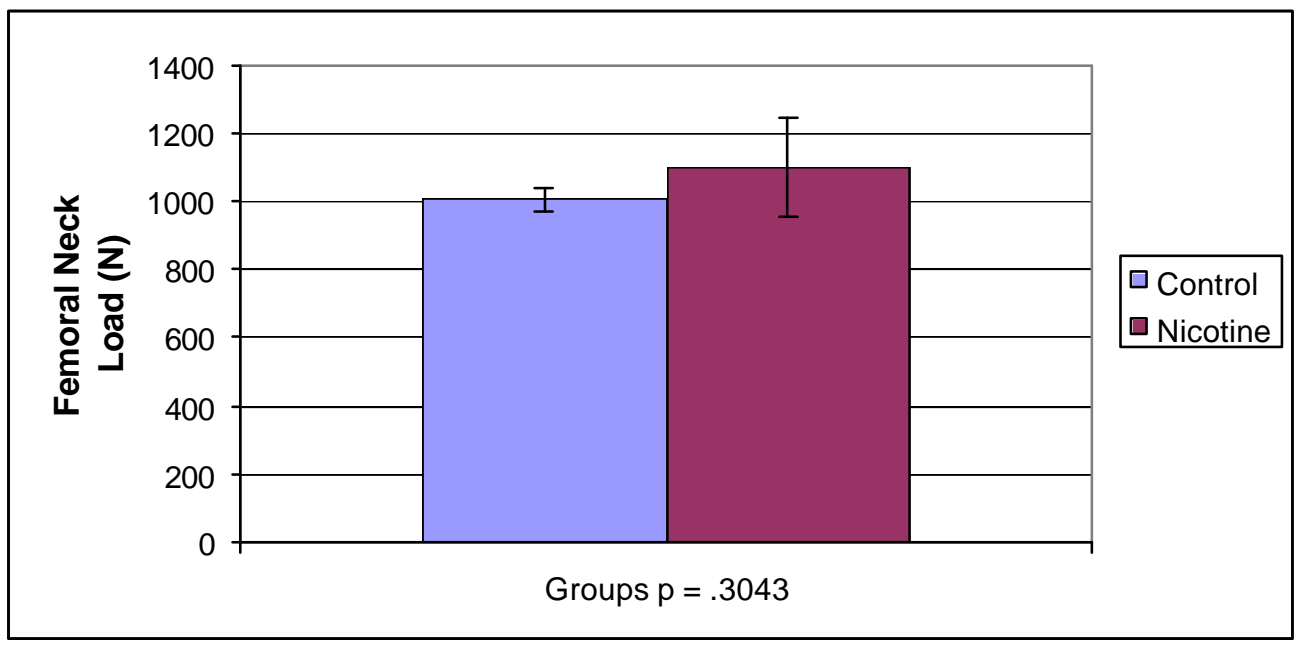

Figure 5.4-2: Femoral Neck load for nicotine and control groups

Table 5.4 - 2: Value for figure 5.4 - 2

\begin{tabular}{|l|r|r|}
\hline Groups & Femoral Neck load (N) & Standard Deviation \\
\hline Control & 1007.286 & 33.55777 \\
\hline Nicotine & 1098.146 & 144.1473 \\
\hline
\end{tabular}




\subsection{Torsion Testing for Experiment 1}

Shear stress for each group is shown in figure 5.5 - 1 and values for figure $5.5-1$ are the values shown in table $5.5-1$ for each group. Figure $5.5-2$ is comparing the nicotine group as a whole versus the control group, and table $5.5-2$ is values for figure $5.5-4$

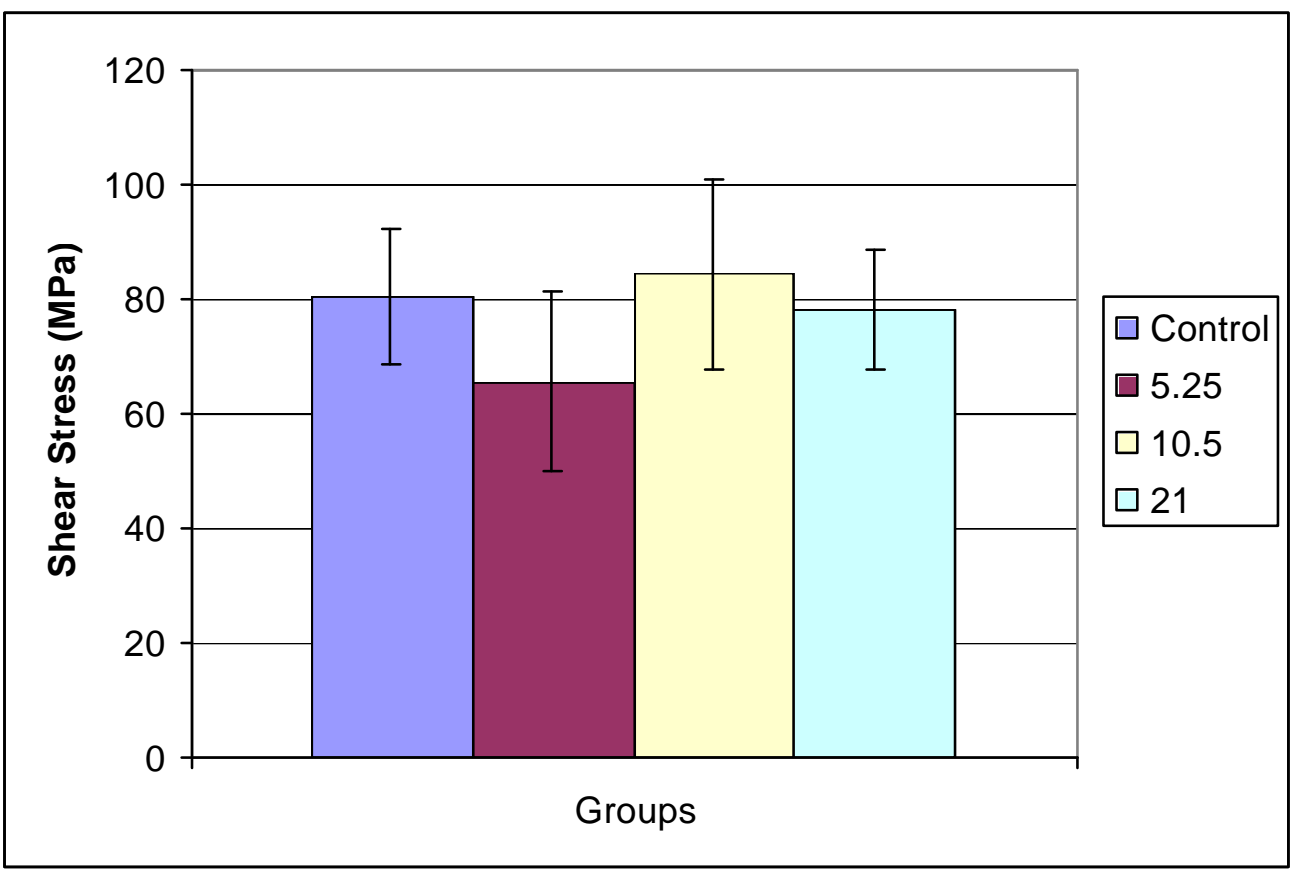

Figure 5.5 - 1: Shear stress for each group

Table 5.5 - 1: Values for figure 5.5 - 1 and $p$ values for each group

\begin{tabular}{|r|r|r|}
\hline Groups & Shear Stress & \multicolumn{2}{|l|}{$\begin{array}{l}\text { Standard } \\
\text { Deviations }\end{array}$} \\
\hline Control & 80.28573 & 11.85253 \\
\hline 5.25 & 65.61587 & 15.62457 \\
\hline 10.5 & 84.43872 & 16.55057 \\
\hline 21 & 78.19599 & 10.45718 \\
\hline
\end{tabular}

\begin{tabular}{|l|r|}
\hline Groups & Prob $>$ F \\
\hline all & 0.2676 \\
\hline $5.25 \&$ C & 0.2352 \\
\hline $10.5 \&$ C & 0.7203 \\
\hline $21 \&$ C & 0.7936 \\
\hline $5.25 \& 10.5$ & 0.1261 \\
\hline $5.25 \& 21$ & 0.1618 \\
\hline $10.5 \& 21$ & 0.4649 \\
\hline
\end{tabular}




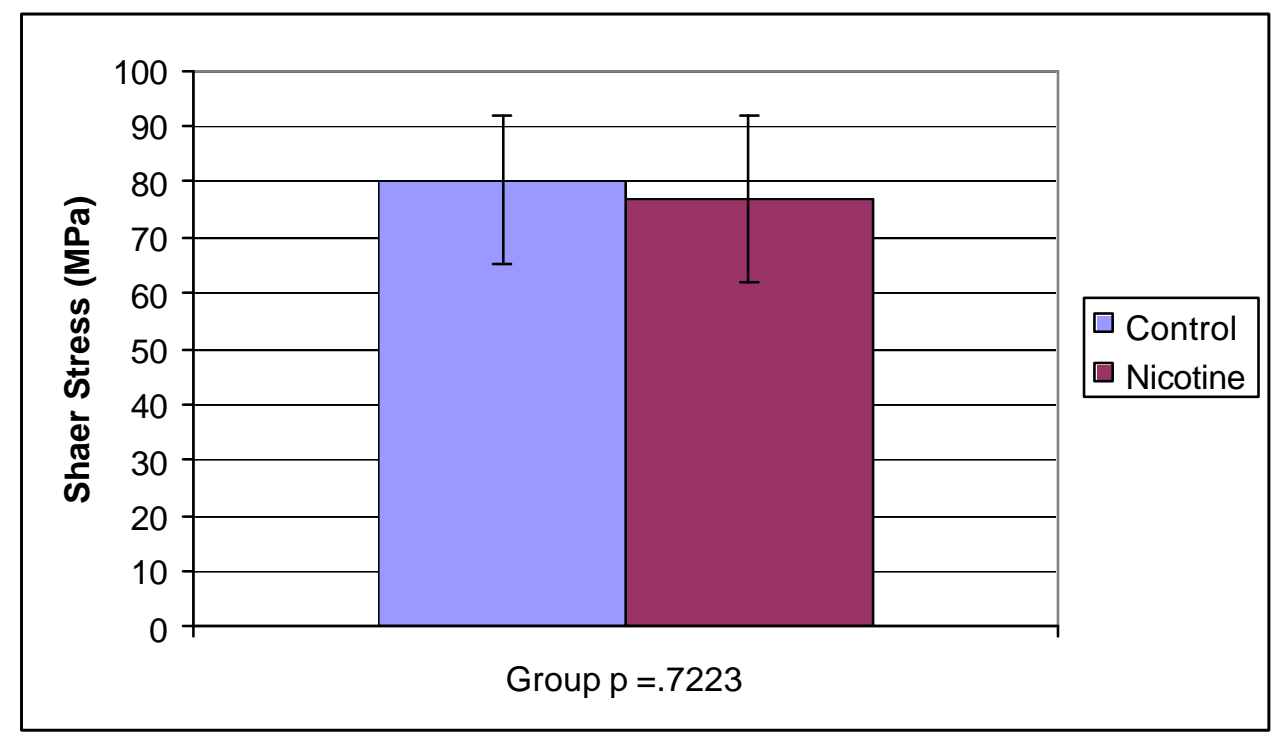

Figure 5.5 - 2: Shear stress for nicotine and control group

Table 5.5 - 2: Values for figure 5.5 - 2

\begin{tabular}{|l|r|r|}
\hline Group & Shear Stress & Standard Deviation \\
\hline Control & 80.28573 & 11.85253 \\
\hline Nicotine & 76.92219 & 15.06744 \\
\hline
\end{tabular}




\subsection{Histomorphometry for Experiment 1}

Figures $5.6-1 \& 2$ and table $5.6-1 \& 2$ is the porosity measurements. Figures $5.63 \& 4$, and table $5.63 \& 4$ is the average pore radius measurements. Figures $5.6-5$ $\& 6$ and table $5.6-5 \& 6$ is the \% Dry Density measurements. Figures $5.6-7 \& 8$ and table $5.6-7 \& 8$ is the \% Wet Density measurements. Figures $5.6-9 \& 10$ and table $5.9-5 \& 10$ is the \% Mineralization measurements. Figures $5.6-11 \& 12$ and table $5.11-5 \& 12$ is the \% Organic Wt. Dry measurements. Figures $5.6-13 \& 14$ and table $5.6-13 \& 14$ is the \% Ash measurements. Figures $5.6-15 \& 16$ and table $5.6-15 \&$ 16 is the \% Organic Wt. Wet measurements. Figures 5.6-17\& 18 and table $5.6-17 \&$ 18 is the \% Water measurements. 


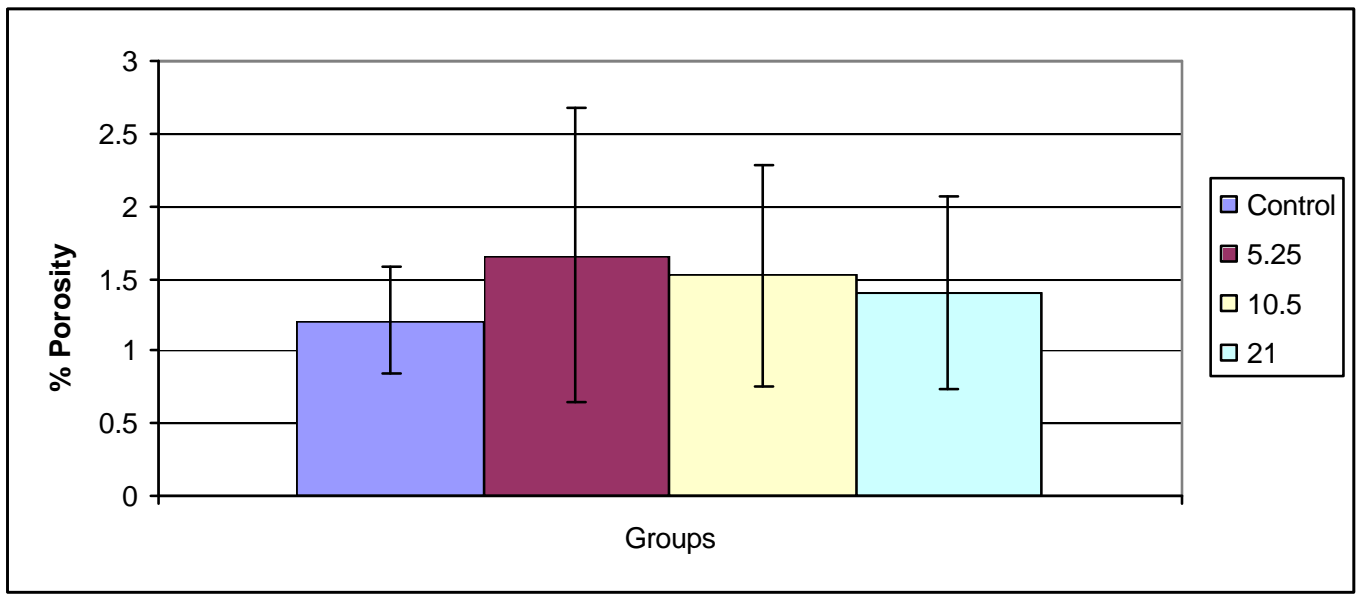

Figure 5.6-1: \% porosity for each group

Table 5.6 - 1: Values for figures 5.6 - 1 and $p$ values for each group

\begin{tabular}{|c|c|c|c|c|}
\hline Groups & $\%$ Porosity & STD & Groups & Prob>F \\
\hline Control & 1.2082 & 0.368 & all & 0.8729 \\
\hline 5.25 & 1.6614 & 1.0105 & $5.25 \& C$ & 0.5 \\
\hline 10.5 & 1.5186 & 0.7644 & $10.5 \& C$ & 0.543 \\
\hline 21 & 1.3991 & 0.668 & $21 \& C$ & 0.6652 \\
\hline & & & $5.25 \& 10.5$ & 0.8153 \\
\hline & & & $5.25 \& 21$ & 0.6308 \\
\hline & & & $10.5 \& 21$ & 0.788 \\
\hline
\end{tabular}

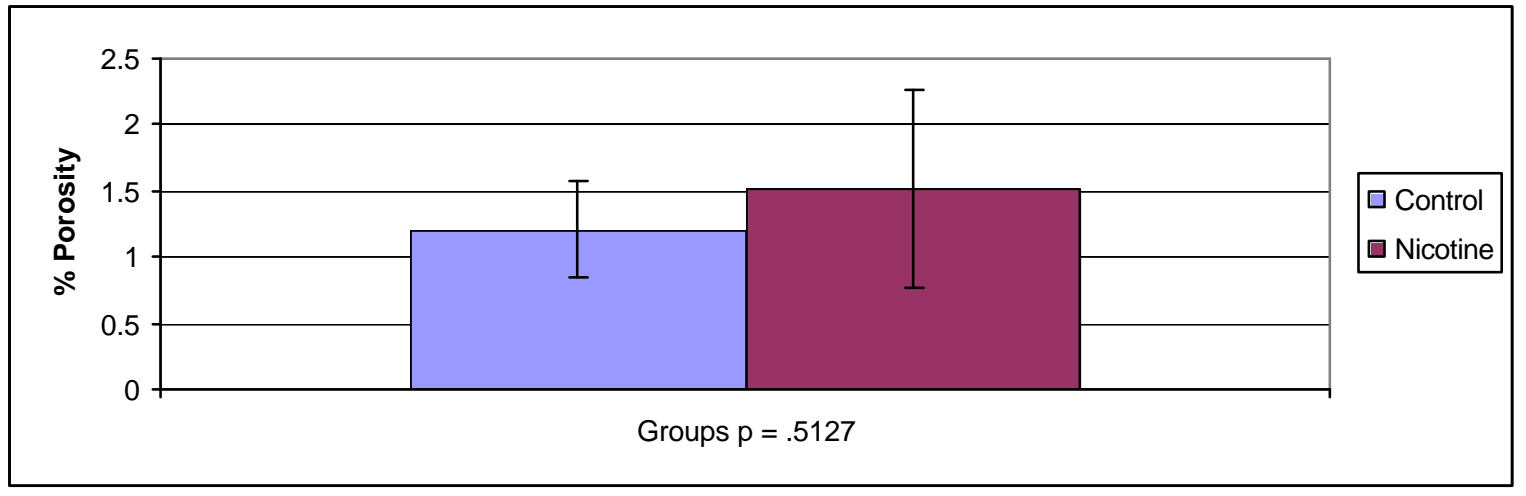

Figure 5.6 - 2: \% Porosity for the nicotine and control groups

Table 5.6 - 2: Values for figure 5.6 - 2

\begin{tabular}{|l|r|r|}
\hline Groups & $\%$ Porosity & $\begin{array}{l}\text { Standard } \\
\text { Deviation }\end{array}$ \\
\hline Control & 0.012082 & 0.00368 \\
\hline Nicotine & 0.015089 & 0.007463 \\
\hline
\end{tabular}




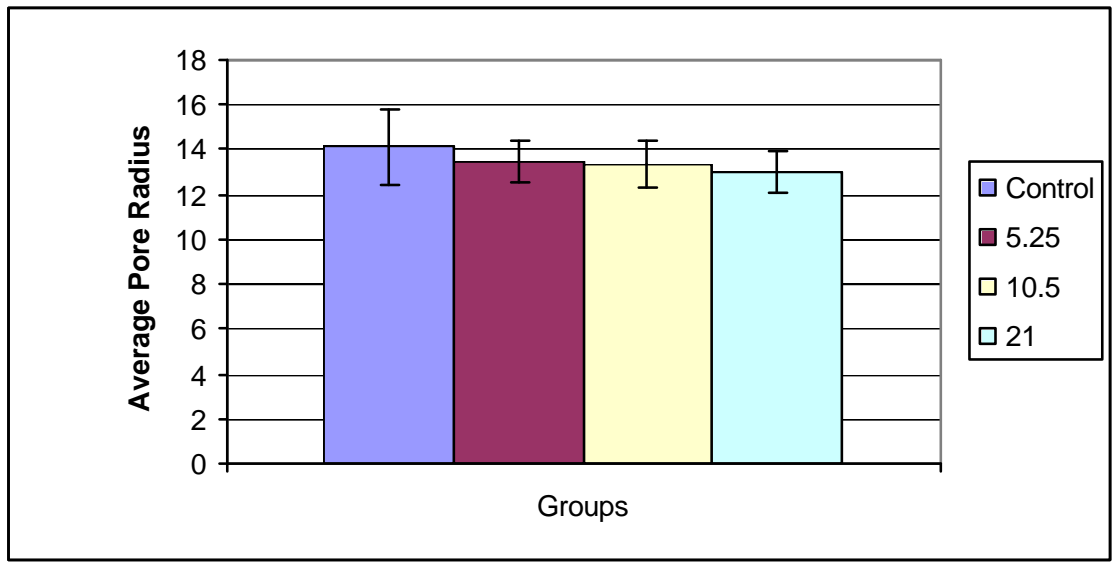

Figure 5.6 - 3: Average Pore Radius for each group

Table 5.6 - 3: Values for figures 5.6 - 3 and $p$ values for each group

\begin{tabular}{|r|r|r|}
\hline Groups & Average Pore Radius & $\begin{array}{l}\text { Standard } \\
\text { Deviation }\end{array}$ \\
\hline Control & 14.11342 & 1.699251 \\
\hline 5.25 & 13.48146 & 0.972664 \\
\hline 10.5 & 13.34851 & 1.049135 \\
\hline 21 & 13.01278 & 0.911264 \\
\hline
\end{tabular}

\begin{tabular}{|l|r|}
\hline Groups & Prob $>$ F \\
\hline all & 0.5843 \\
\hline $5.25 \&$ C & 0.5561 \\
\hline $10.5 \&$ C & 0.452 \\
\hline $21 \&$ C & 0.2325 \\
\hline $5.25 \& 10.5$ & 0.851 \\
\hline $5.25 \& 21$ & 0.4596 \\
\hline $10.5 \& 21$ & 0.5835 \\
\hline
\end{tabular}

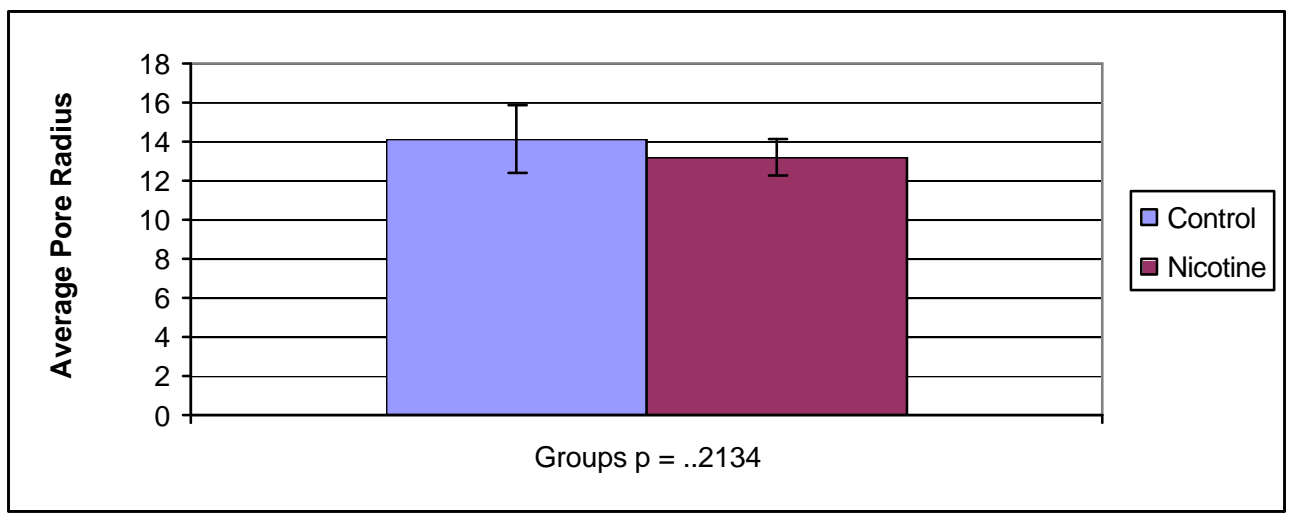

Figure 5.6 - 4: Average Pore Radius for the nicotine and control group

Table 5.6 - 4: Values for Figure 5.6 - 4

\begin{tabular}{|l|c|r|}
\hline Groups & Average Pore Radius & Standard Deviation \\
\hline Control & 14.11342 & 1.699251 \\
\hline Nicotine & 13.24967 & 0.925567 \\
\hline
\end{tabular}




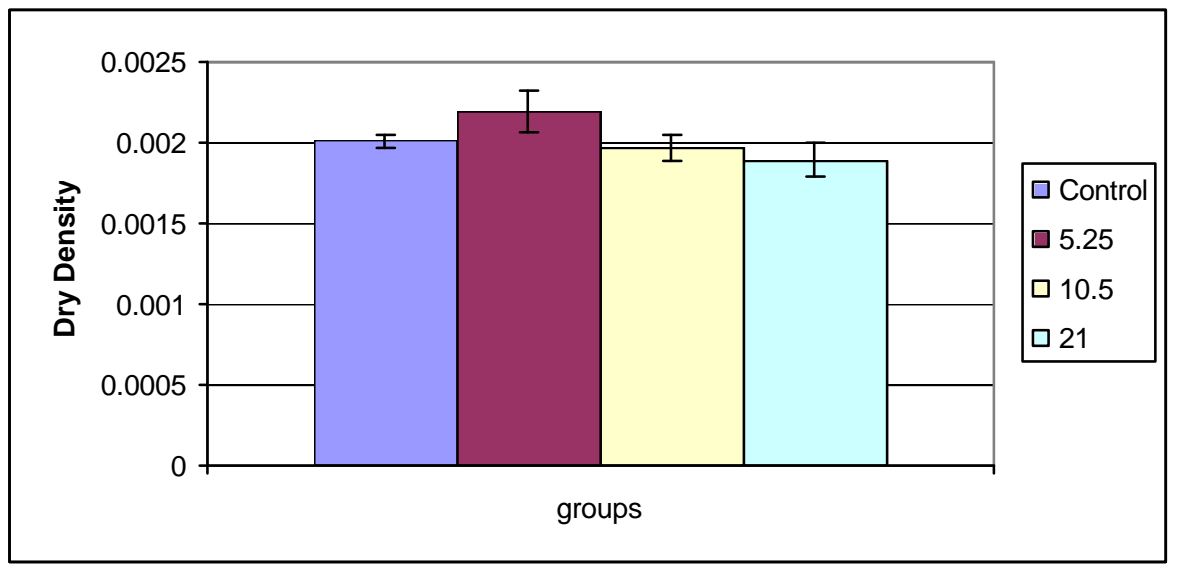

Figure 5.6 - 5: Dry Density \% for the groups

Table 5.6 - 5: Values for figures 5.6 - 5 and $p$ values for each group

\begin{tabular}{|r|r|r|}
\hline groups & \%Dry Density & Standard Deviation \\
\hline Control & 0.002009 & 0.000046 \\
\hline 5.25 & 0.002193 & 0.000126 \\
\hline 10.5 & 0.001971 & 0.000083 \\
\hline 21 & 0.001893 & 0.0001 \\
\hline
\end{tabular}

\begin{tabular}{|l|r|}
\hline Groups & Prob $>\mathbf{F}$ \\
\hline all & 0.0025 \\
\hline $5.25 \&$ C & 0.0643 \\
\hline $10.5 \&$ C & 0.5042 \\
\hline $21 \&$ C & 0.107 \\
\hline $5.25 \& 10.5$ & 0.0154 \\
\hline $5.25 \& 21$ & 0.003 \\
\hline $10.5 \& 21$ & 0.2026 \\
\hline
\end{tabular}

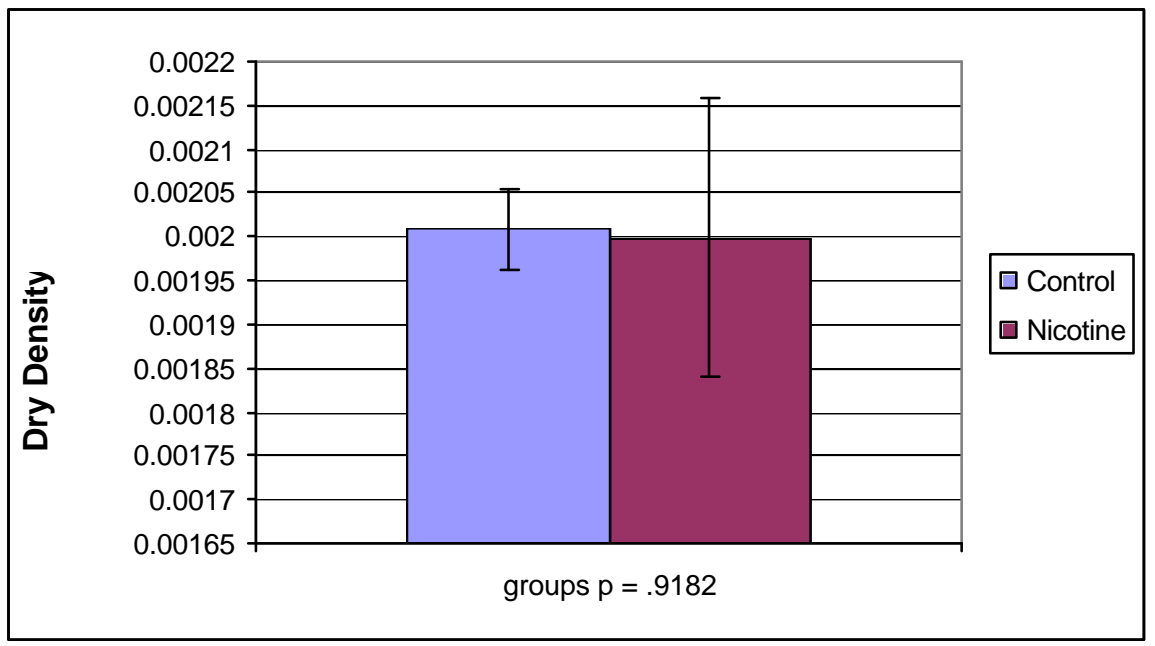

Figure 5.6 - 6: \% Dry Density for nicotine and control groups

Table 5.6 - 6: Values for figure 5.6 - 6

\begin{tabular}{|l|r|r|}
\hline groups & $\%$ Dry Density & Standard Deviation \\
\hline Control & 0.002009 & 0.000046 \\
\hline Nicotine & 0.001999 & 0.000158 \\
\hline
\end{tabular}




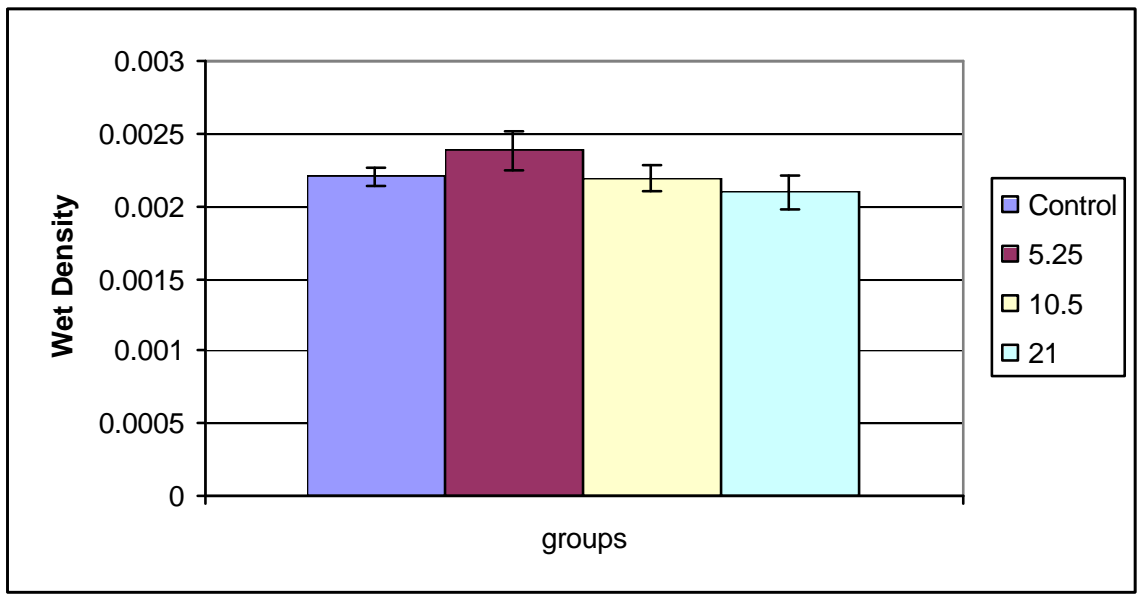

Figure 5.6 - 7: \% Wet Density for all groups

Table 5.6 - 7: Values for figures 5.6 - 7 and $p$ values for each group

\begin{tabular}{|r|r|r|}
\hline groups & \% Wet Density & Standard Deviation \\
\hline Control & 0.002204 & 0.000062 \\
\hline 5.25 & 0.002387 & 0.000135 \\
\hline 10.5 & 0.002199 & 0.00009 \\
\hline 21 & 0.002093 & 0.000109 \\
\hline
\end{tabular}

\begin{tabular}{|l|r|}
\hline Groups & Prob>F \\
\hline all & 0.0062 \\
\hline 5.25 \& C & 0.0836 \\
\hline 10.5 \& C & 0.9404 \\
\hline 21 \& & 0.1532 \\
\hline $5.25 \& 10.5$ & 0.9856 \\
\hline $5.25 \& 21$ & 0.0051 \\
\hline $10.5 \& 21$ & 0.1161 \\
\hline
\end{tabular}

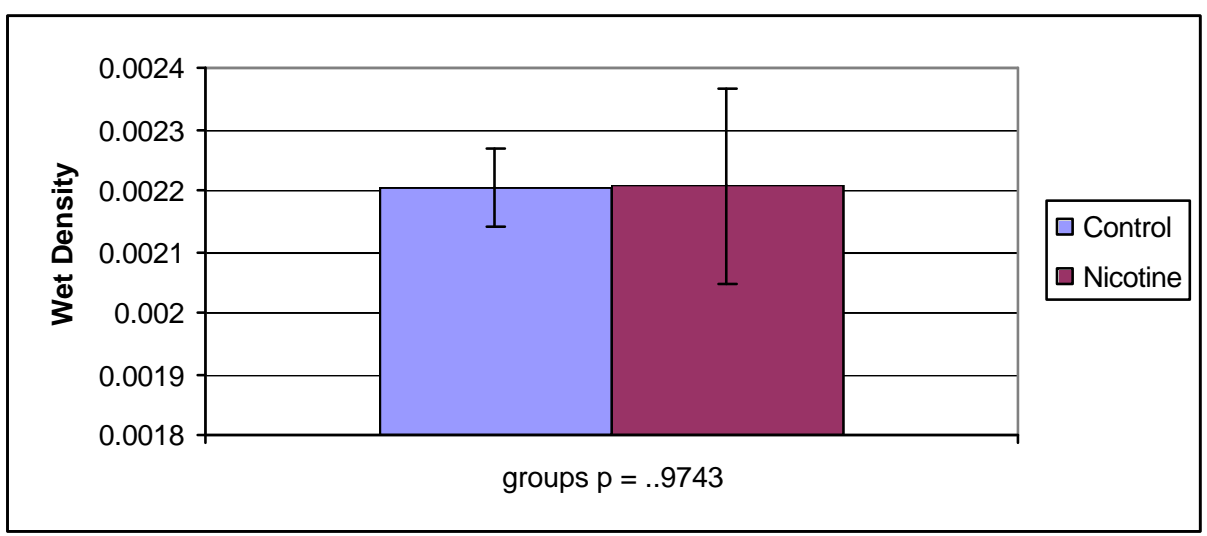

Figure 5.6 - 8: \% Wet Density for nicotine and control groups

Table 5.6 - 8: Values for figures 5.6 - 8

\begin{tabular}{|l|r|r|}
\hline groups & $\%$ Wet Density & Standard Deviation \\
\hline Control & 0.002204 & 0.000062 \\
\hline Nicotine & 0.002207 & 0.000159 \\
\hline
\end{tabular}




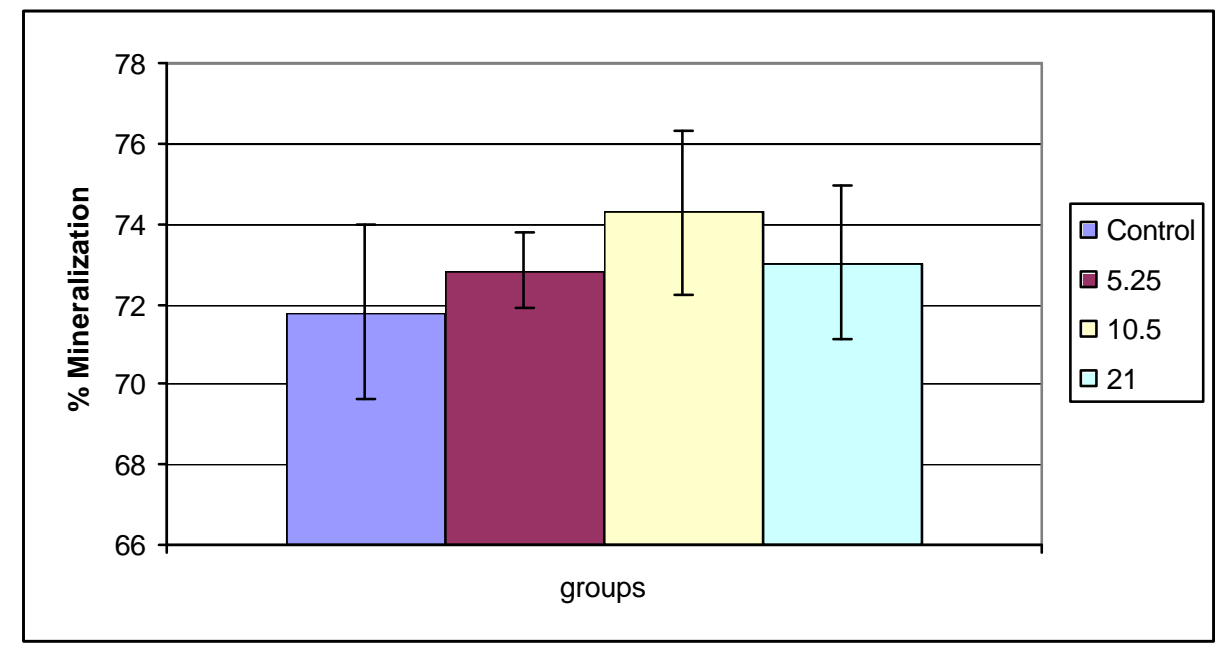

Figure 5.6 - 9: \% Mineralization for all groups

Table 5.6 - 9: Values for figures 5.6 - 9 and $p$ values for each group

\begin{tabular}{|r|r|r|}
\hline groups & \% Mineralization & Standard Deviation \\
\hline Control & 71.79066 & 2.161804 \\
\hline 5.25 & 72.84097 & 0.914438 \\
\hline 10.5 & 74.29161 & 2.044408 \\
\hline 21 & 73.03156 & 1.938047 \\
\hline
\end{tabular}

\begin{tabular}{|l|r|}
\hline Groups & Prob $>$ F \\
\hline all & 0.3345 \\
\hline $5.25 \&$ C & 0.4127 \\
\hline $10.5 \&$ C & 0.1515 \\
\hline $21 \&$ C & 0.4104 \\
\hline $5.25 \& 10.5$ & 0.2332 \\
\hline $5.25 \& 21$ & 0.8609 \\
\hline $10.5 \& 21$ & 0.3221 \\
\hline
\end{tabular}

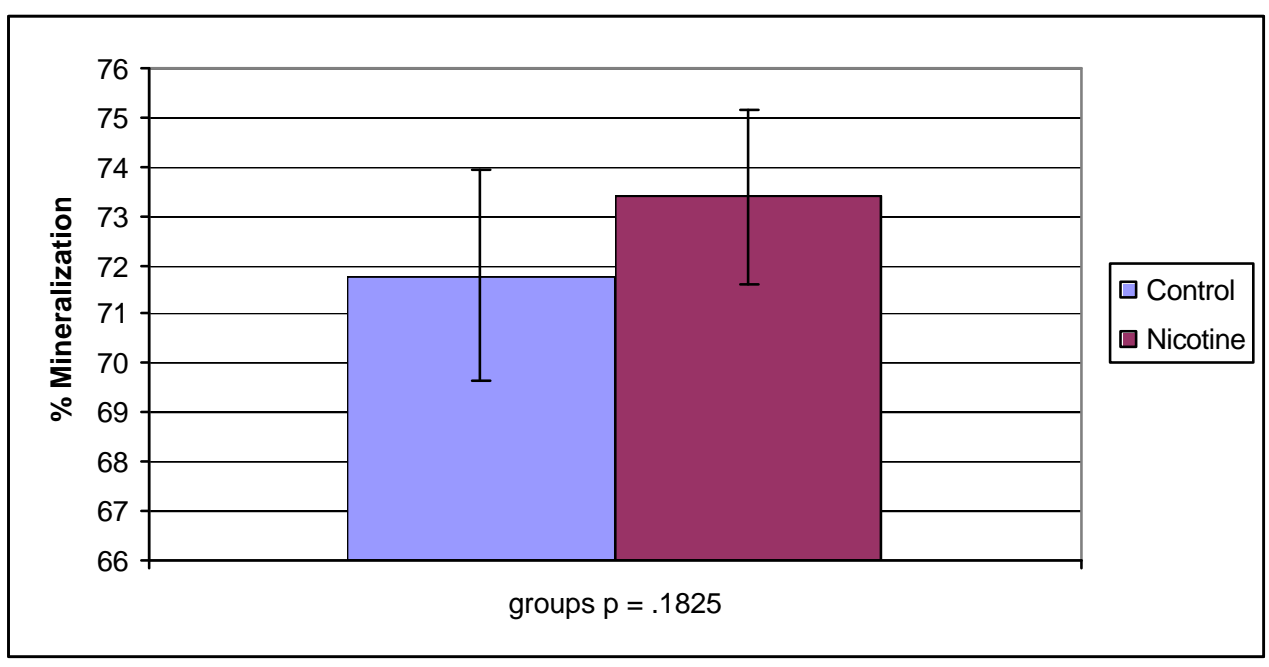

Figure 5.6 - 10: \% Mineralization for nicotine and control groups

Table 5.6 - 10: Values for figures 5.6 - 10

\begin{tabular}{|l|r|r|}
\hline groups & $\%$ Mineralization & Standard Deviation \\
\hline Control & 71.79066 & 2.161804 \\
\hline Nicotine & 73.40075 & 1.773747 \\
\hline
\end{tabular}




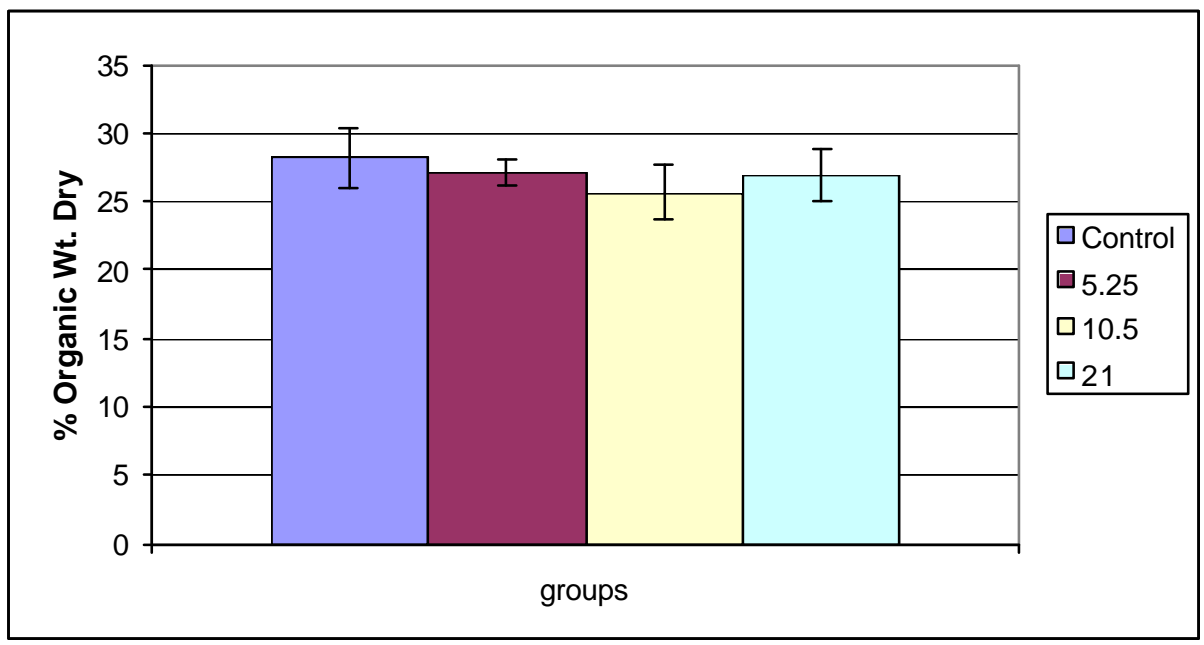

Figure 5.6 - 11: \% Organic Wt. Dry for all groups

Table 5.6 - 11: Values for figures 5.6 - 11 and $p$ values for each group

\begin{tabular}{|r|r|r|}
\hline groups & $\%$ Organic wt. Dry & Standard Deviation \\
\hline Control & 28.20934 & 2.161804 \\
\hline 5.25 & 27.15903 & 0.914438 \\
\hline 10.5 & 25.70839 & 2.044408 \\
\hline 21 & 26.96844 & 1.938047 \\
\hline
\end{tabular}

\begin{tabular}{|l|r|}
\hline Groups & Prob $>$ F \\
\hline all & 0.3345 \\
\hline $5.25 \&$ C & 0.4127 \\
\hline $10.5 \&$ C & 0.1515 \\
\hline $21 \&$ C & 0.4104 \\
\hline $5.25 \& 10.5$ & 0.2332 \\
\hline $5.25 \& 21$ & 0.8609 \\
\hline $10.5 \& 21$ & 0.3221 \\
\hline
\end{tabular}

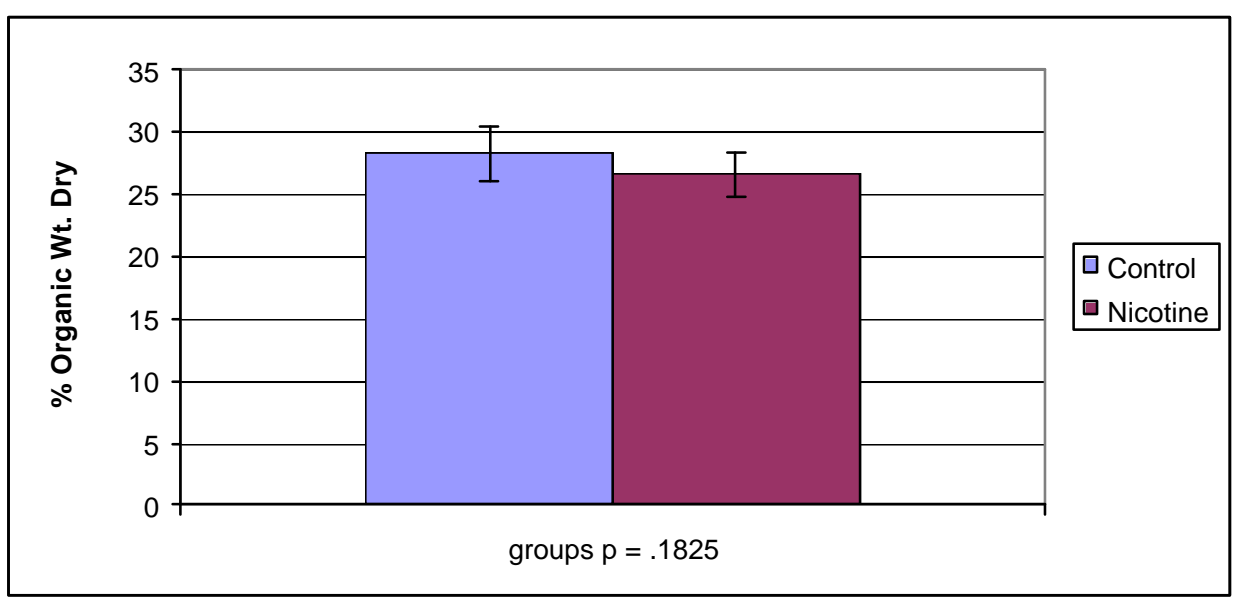

Figure 5.6 - 12: \% Organic Dry for nicotine and control groups

Table 5.6 - 12: Values for figures 5.6 - 12

\begin{tabular}{|l|r|r|}
\hline groups & $\%$ Organic Wt. Dry & Standard Deviation \\
\hline Control & 28.20934 & 2.161804 \\
\hline Nicotine & 26.59925 & 1.773747 \\
\hline
\end{tabular}




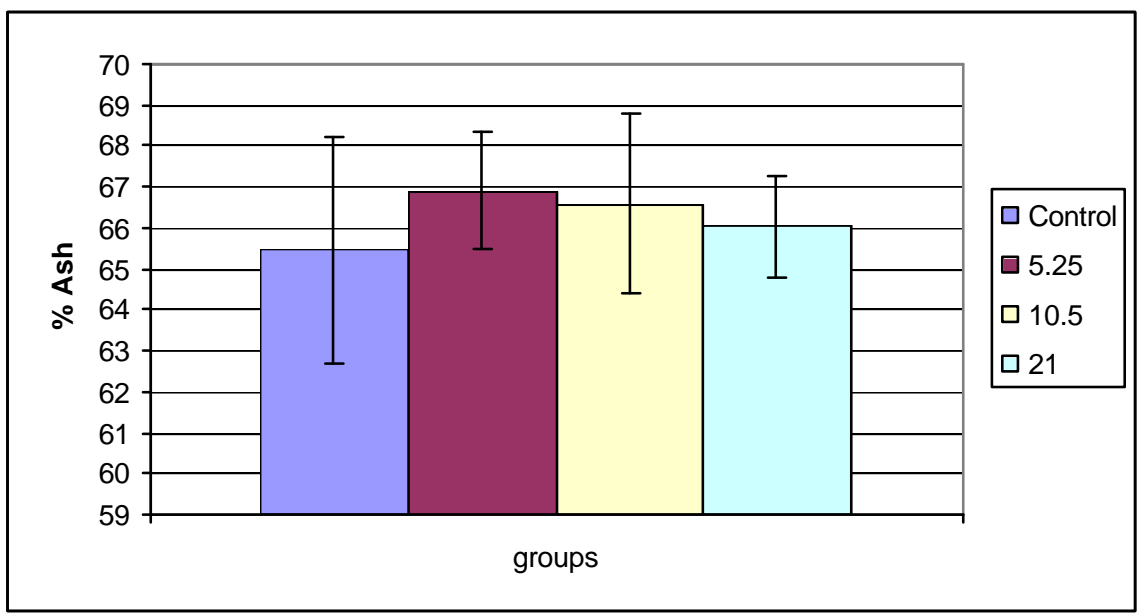

Figure 5.6-13: \% Ash for all groups

Table 5.6 - 13: Values for figures 5.6 - 13 and $p$ values for each group

\begin{tabular}{|r|r|r|}
\hline groups & $\%$ Ash & Standard Deviation \\
\hline Control & 65.45607 & 2.736882 \\
\hline 5.25 & 66.90258 & 1.431898 \\
\hline 10.5 & 66.57826 & 2.191925 \\
\hline 21 & 66.04006 & 1.250519 \\
\hline
\end{tabular}

\begin{tabular}{|l|r|}
\hline Groups & Prob $>\mathbf{F}$ \\
\hline all & 0.7388 \\
\hline $5.25 \&$ C & 0.3992 \\
\hline $10.5 \&$ C & 0.5436 \\
\hline $21 \&$ C & 0.6611 \\
\hline $5.25 \& 10.5$ & 0.8068 \\
\hline $5.25 \& 21$ & 0.3415 \\
\hline $10.5 \& 21$ & 0.6204 \\
\hline
\end{tabular}

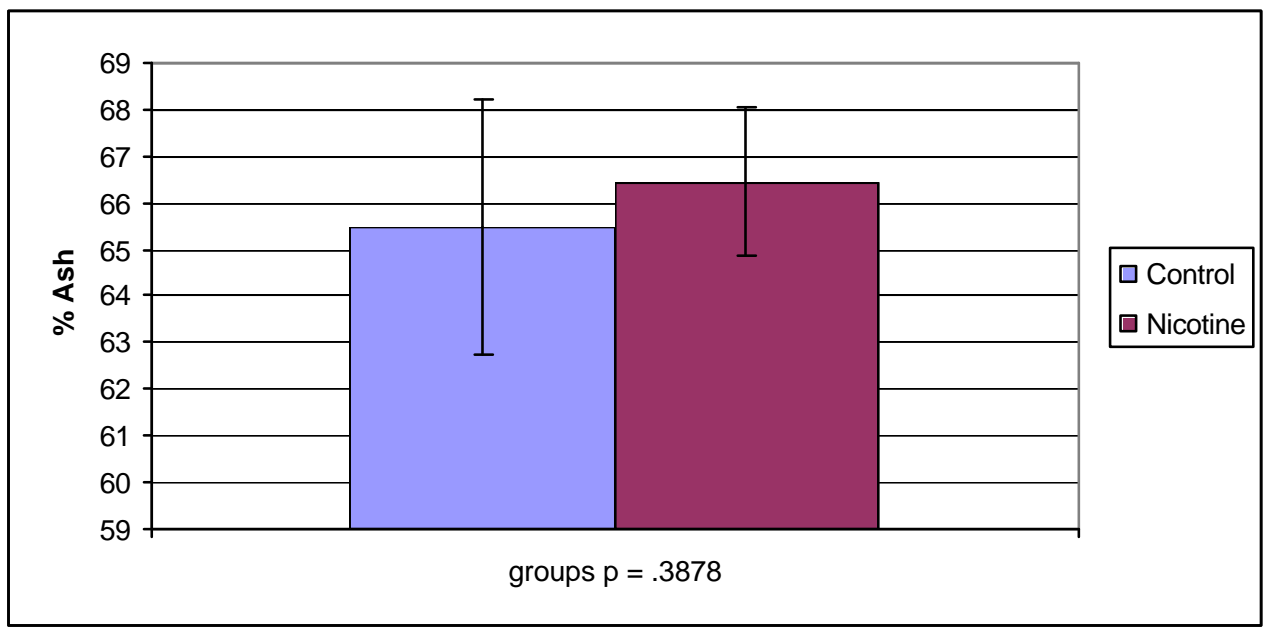

Figure 5.6 - 14: \% Ash for nicotine and control groups

Table 5.6 - 14: Values for figures 5.6 - 14

\begin{tabular}{|l|r|r|}
\hline groups & $\%$ Ash & Standard Deviation \\
\hline Control & 65.45607 & 2.736882 \\
\hline Nicotine & 66.44947 & 1.583351 \\
\hline
\end{tabular}




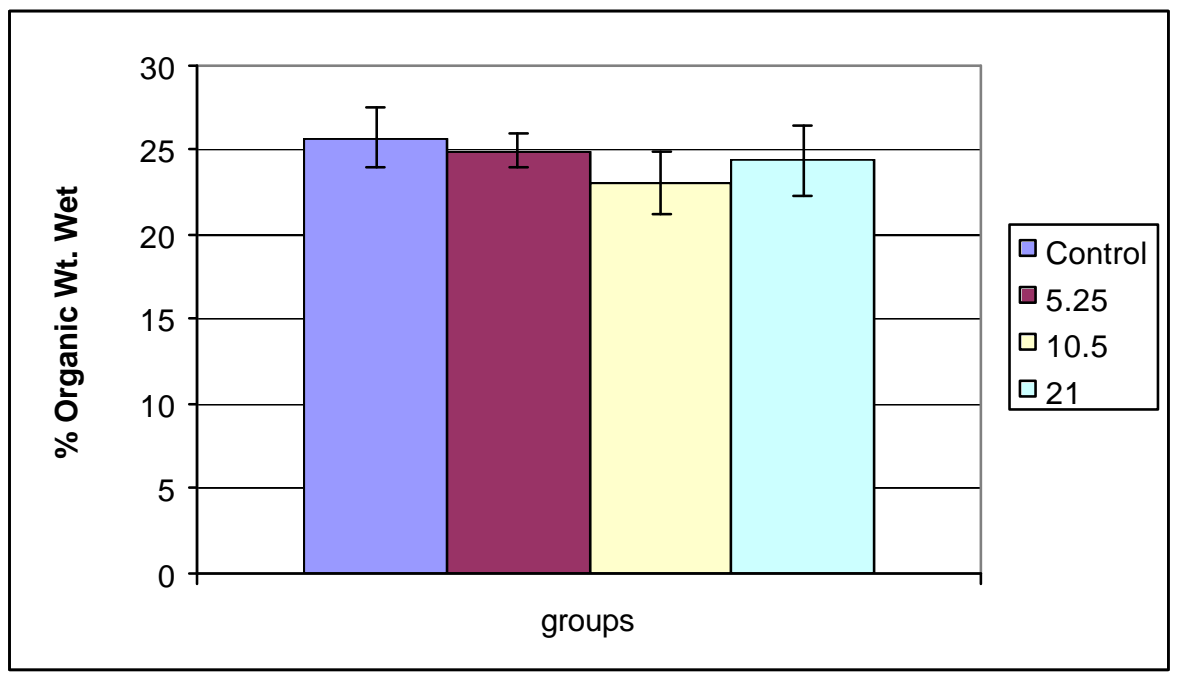

Figure 5.6 - 15: \% Organic Wt. Wet for all groups

Table 5.6 - 15: Values for figures 5.6 - 15 and $p$ values for each group

\begin{tabular}{|r|r|r|}
\hline groups & \%Organic wt. Wet & Standard Deviation \\
\hline Control & 25.70161 & 1.737238 \\
\hline 5.25 & 24.94712 & 1.021928 \\
\hline 10.5 & 23.03476 & 1.824483 \\
\hline 21 & 24.41216 & 2.096796 \\
\hline
\end{tabular}

\begin{tabular}{|l|r|}
\hline Groups & Prob $>F$ \\
\hline all & 0.2264 \\
\hline 5.25 \& C & 0.4984 \\
\hline 10.5 \& C & 0.0882 \\
\hline 21 \& & 0.3924 \\
\hline $5.25 \& 10$. & 0.1052 \\
\hline $5.25 \& 21$ & 0.6525 \\
\hline 10.5 \& 21 & 0.2803 \\
\hline
\end{tabular}

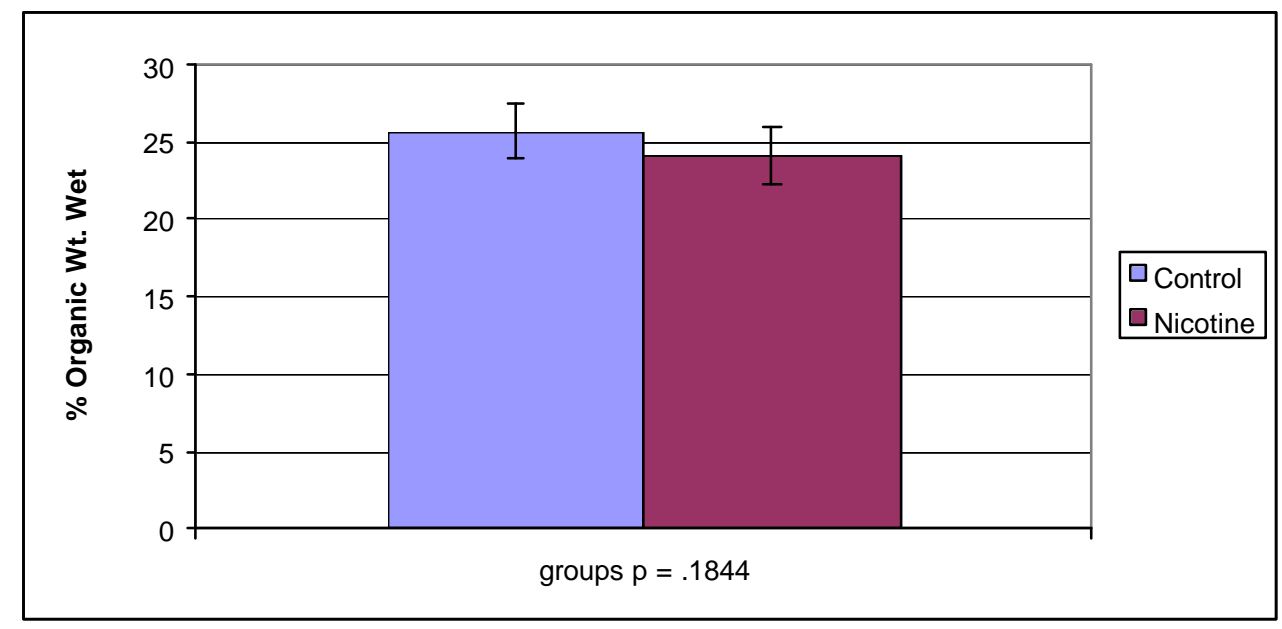

Figure 5.6-16: \% Organic Wt. Wet for nicotine and control groups

Table 5.6 - 16: Values for figures 5.6 - 16

\begin{tabular}{|l|r|r|}
\hline groups & \%Organic Wt. Wet & Standard Deviation \\
\hline Control & 25.70161 & 1.737238 \\
\hline Nicotine & 24.09568 & 1.84312 \\
\hline
\end{tabular}




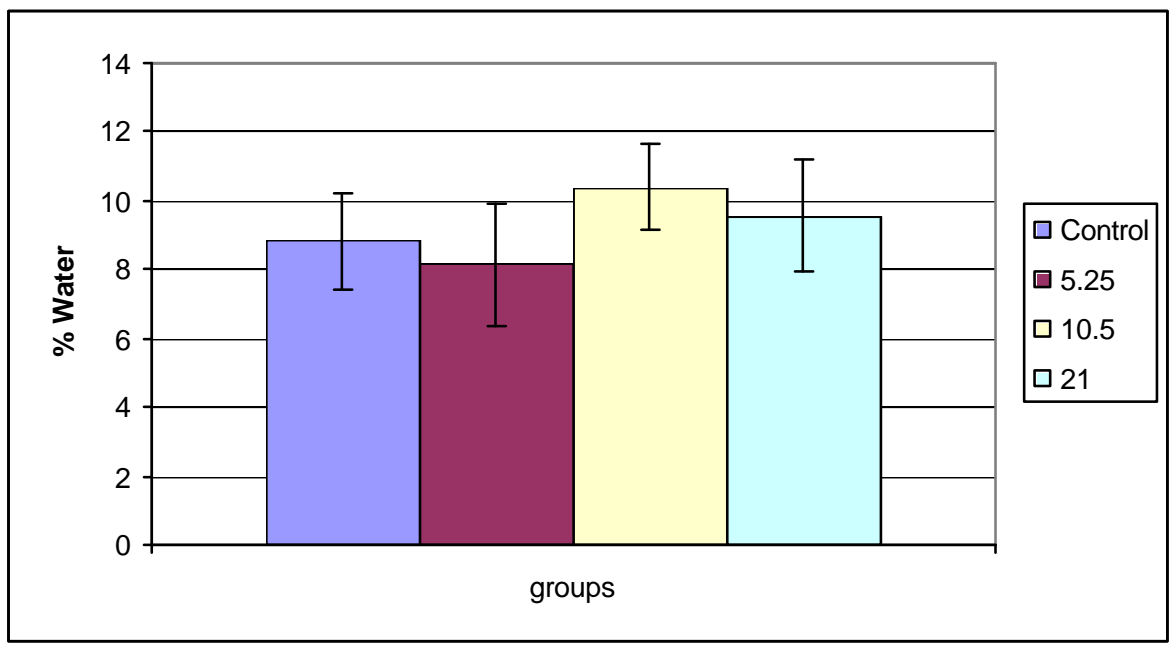

Figure 5.6 - 17: \% Water for all groups

Table 5.6 - 17: Values for figures 5.6 - 17 and $p$ values for each group

\begin{tabular}{|r|r|r|}
\hline groups & $\%$ Water & Standard Deviation \\
\hline Control & 8.842324 & 1.398437 \\
\hline 5.25 & 8.150296 & 1.773523 \\
\hline 10.5 & 10.38698 & 1.258453 \\
\hline 21 & 9.547779 & 1.634604 \\
\hline
\end{tabular}

\begin{tabular}{|l|r|}
\hline Groups & Prob>F \\
\hline all & 0.2097 \\
\hline 5.25 \& C & 0.6031 \\
\hline 10.5 \& C & 0.1567 \\
\hline 21 \& C & 0.5455 \\
\hline 5.25 \& 10.4 & 0.0618 \\
\hline 5.25 \& 21 & 0.2356 \\
\hline 10.5 \& 21 & 0.3733 \\
\hline
\end{tabular}

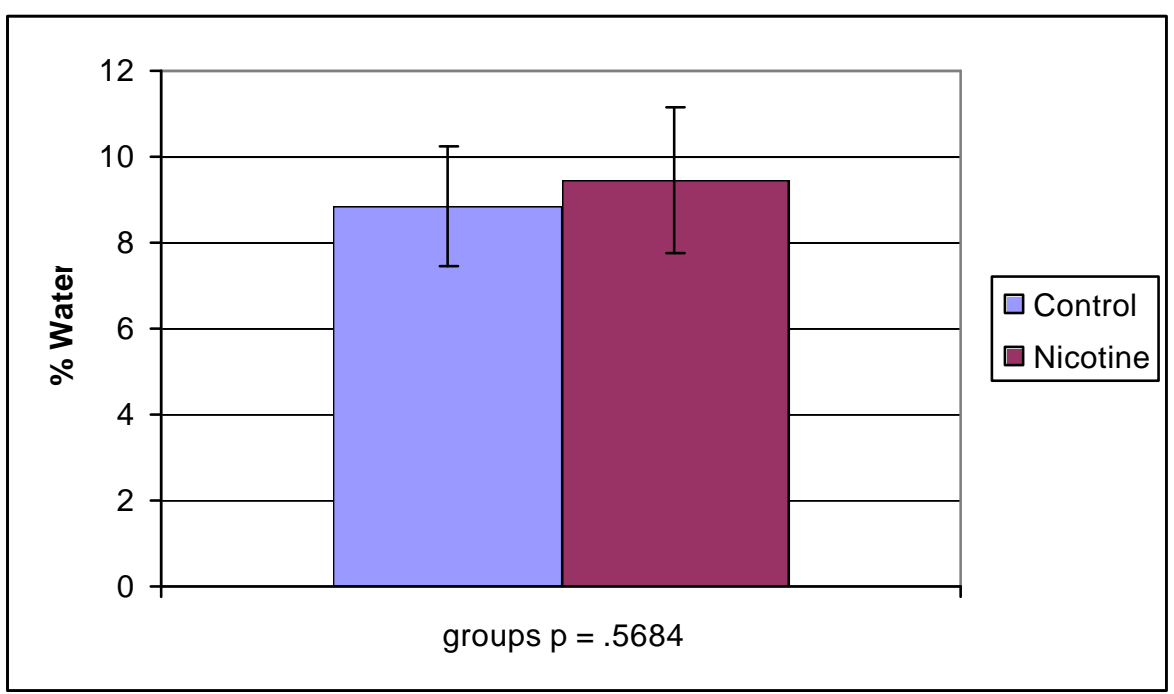

Figure 5.6 - 18: \% Water for nicotine and control groups

Table 5.6 - 18: Values for figures 5.6 - 18

\begin{tabular}{|l|r|r|}
\hline groups & $\%$ Water & Standard Deviation \\
\hline Control & 8.842324 & 1.398437 \\
\hline Nicotine & 9.454851 & 1.697356 \\
\hline
\end{tabular}




\subsection{Weight and Nicotine Levels for Experiment 2}

All individual test data for each rabbit is in Appendix B for group 2.

For week one blood draw for Rabbit F8 no blood could be obtained from the rabbit. This affected the average nicotine level seen for the 5 week smoking group. Figure $5.7-1$ and table $5.7-1$ is the average nicotine level seen during the 5 weeks. Figure $5.7-2$ and table $5.7-2$ is the nicotine level for each measurement seen during the 5 weeks. Figure $5.7-3$ and table $5.7-3$ is the average weight difference seen during the 5 weeks. Figure $5.7-4$ and table $5.7-4$ is the weight for each measurement seen during the 5 weeks. 


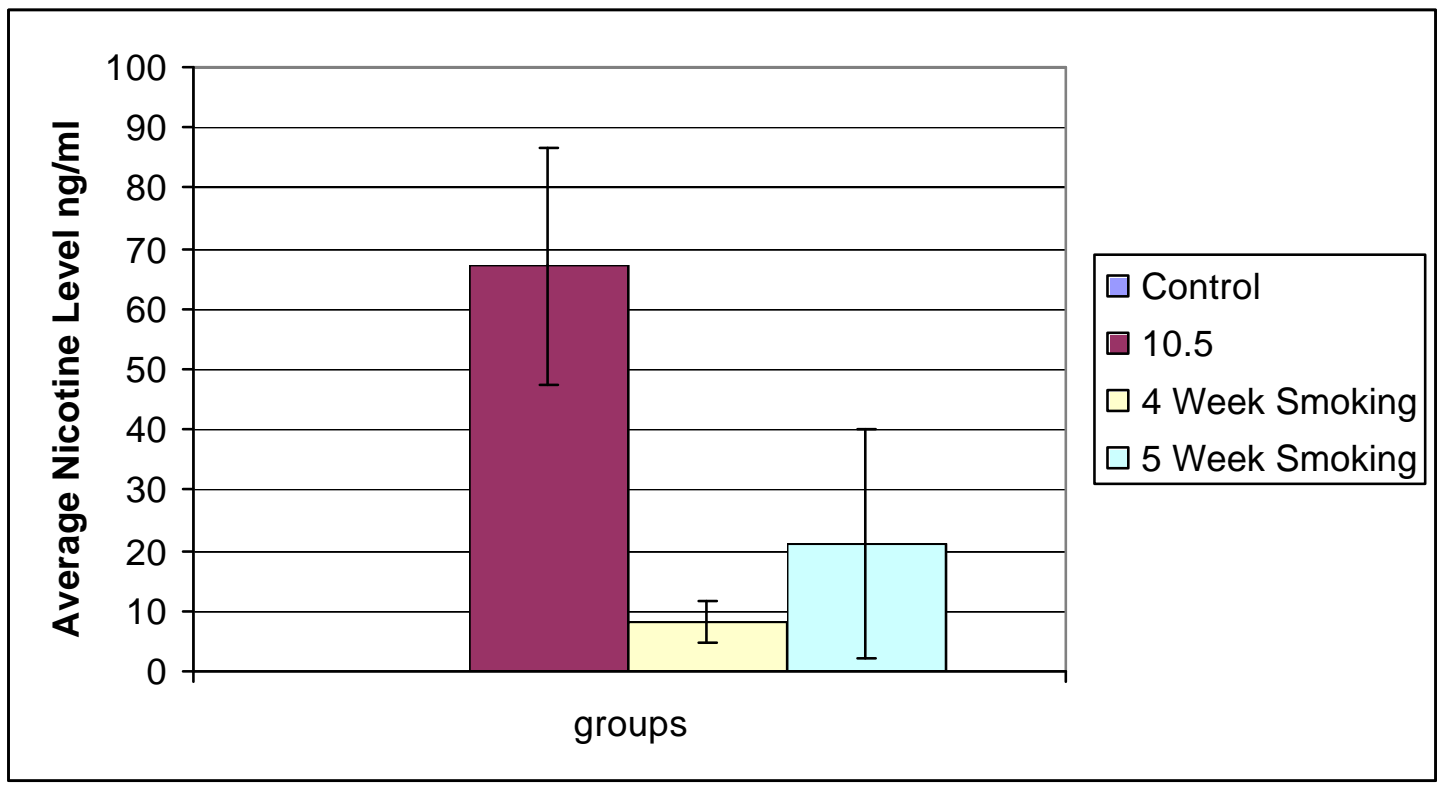

Figure 5.7 - 1: Average nicotine level seen in each group during the 5 week period

Table 5.7 - 1: Value for figure 5.7 - 1 and $p$ values for each group

\begin{tabular}{|l|r|r|}
\hline groups & $\begin{array}{l}\text { Nicotine } \\
\text { Level (ng/ml) }\end{array}$ & $\begin{array}{l}\text { Standard } \\
\text { Devation }\end{array}$ \\
\hline Control & 0 & 0 \\
\hline 10.5 & 67.11111 & 19.55974 \\
\hline 4 Week Smoking & 8.161111 & 3.580777 \\
\hline 5 Week Smoking & 21.26111 & 18.95643 \\
\hline
\end{tabular}

\begin{tabular}{|l|r|}
\hline Groups & P values \\
\hline ALL & 0.0001 \\
\hline Control vs 10.5 & 0.0001 \\
\hline Control vs 4 weeks smoking & 0.0007 \\
\hline Control vs 5 weeks smoking & 0.0347 \\
\hline 10.5 vs 4 weeks smoking & 0.0001 \\
\hline 10.5 vs 5 weeks smoking & 0.0006 \\
\hline 4 vs 5 weeks smoking & 0.1272 \\
\hline
\end{tabular}




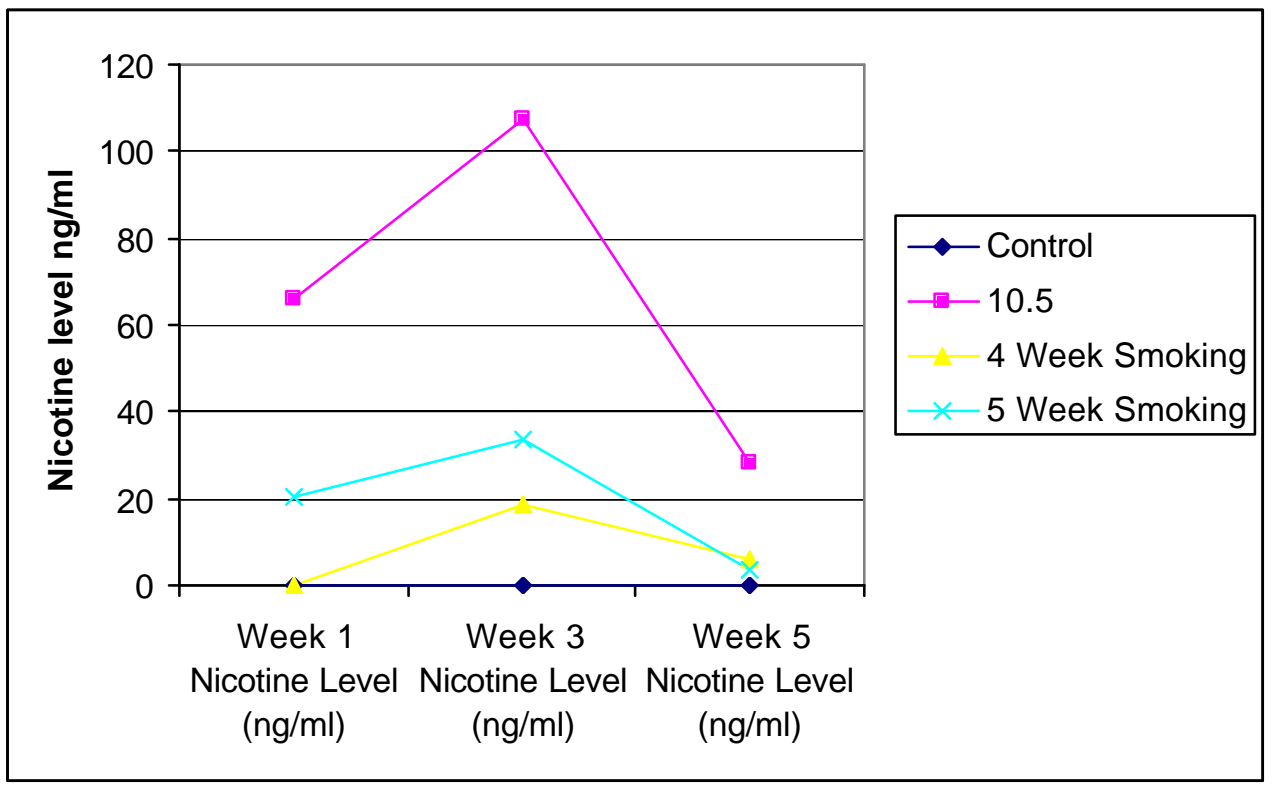

Figure 5.7 - 2: Nicotine levels during the 5 weeks period

Table 5.7 - 2: Values for figure 5.7 - 2

\begin{tabular}{|l|l|l|l|}
\hline groups & $\begin{array}{l}\text { Week 1 Nicotine } \\
\text { Level (ng/ml) }\end{array}$ & $\begin{array}{l}\text { Week 3 Nicotine } \\
\text { Level (ng/ml) }\end{array}$ & $\begin{array}{l}\text { Week 5 Nicotine } \\
\text { Level (ng/ml) }\end{array}$ \\
\hline Control & 0 & 0 & 0 \\
\hline 10.5 & 66.22222 & 107.1111 & 28 \\
\hline 4 Week Smoking & 0 & 18.66667 & 5.816667 \\
\hline 5 Week Smoking & 20.14 & 33.78333 & 3.483333 \\
\hline
\end{tabular}




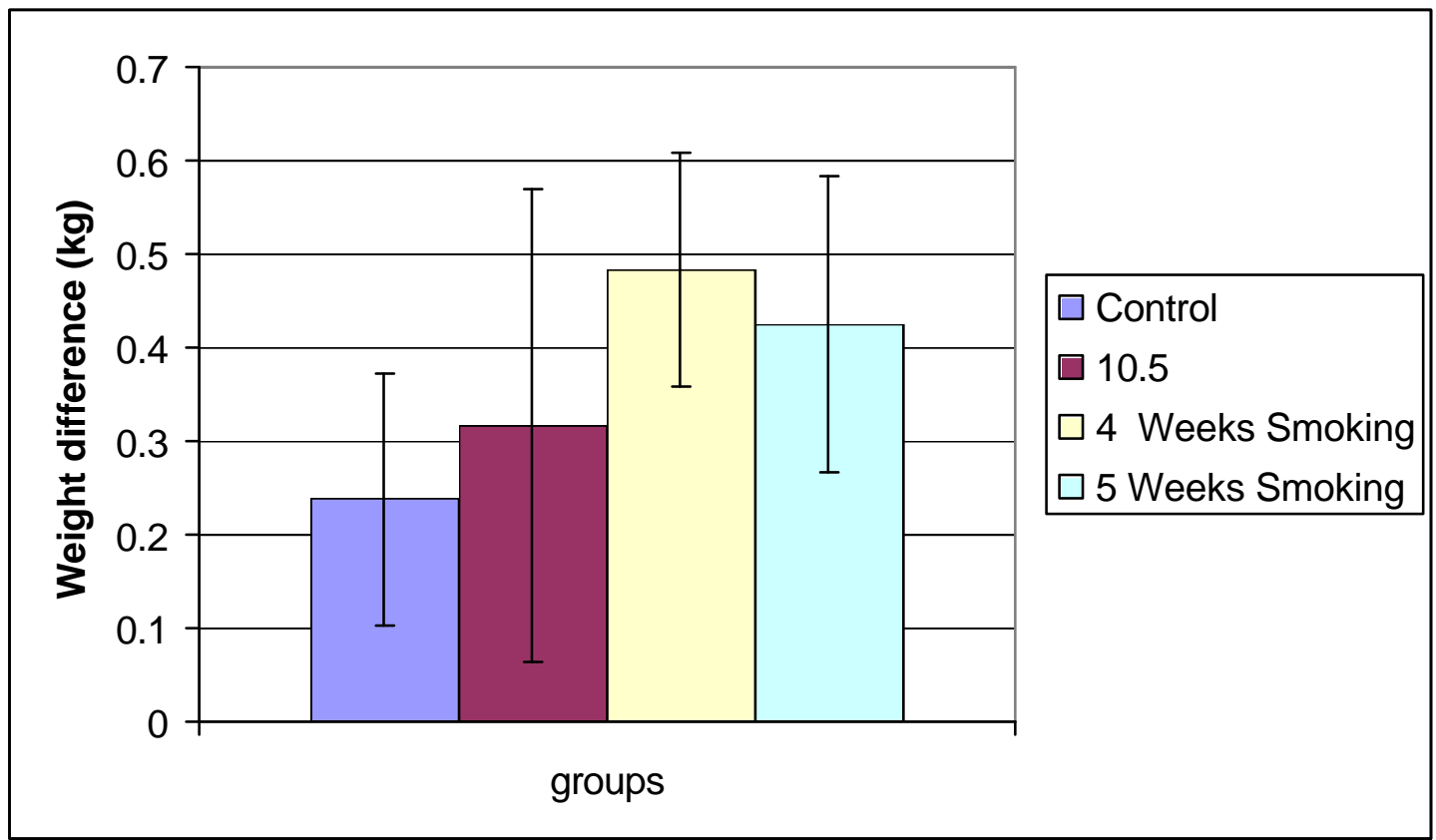

Figure 5.7-3: Average Weight of the rabbits during the 5-week period

Table 5.7 - 3: Values for figure 5.7 - 3 and p values for each group

\begin{tabular}{|l|r|r|}
\hline groups & \multicolumn{1}{|l|}{$\begin{array}{l}\text { Weight } \\
\text { Differenece }\end{array}$} & $\begin{array}{l}\text { Stanrdard } \\
\text { Devation }\end{array}$ \\
\hline Control & 0.238 & 0.134052 \\
\hline 10.5 & 0.315556 & 0.252938 \\
\hline 4 Weeks Smoking & 0.483333 & 0.125645 \\
\hline 5 Weeks Smoking & 0.425 & 0.159217 \\
\hline
\end{tabular}

\begin{tabular}{|l|r|}
\hline Groups & P values \\
\hline ALL & 0.1535 \\
\hline Control vs 10.5 & 0.5402 \\
\hline Control vs 4 weeks smoking & 0.0121 \\
\hline Control vs 5 weeks smoking & 0.0674 \\
\hline 10.5 vs 4 weeks smoking & 0.1592 \\
\hline 10.5 vs 5 weeks smoking & 0.3659 \\
\hline 4 vs 5 weeks smoking & 0.4972 \\
\hline
\end{tabular}




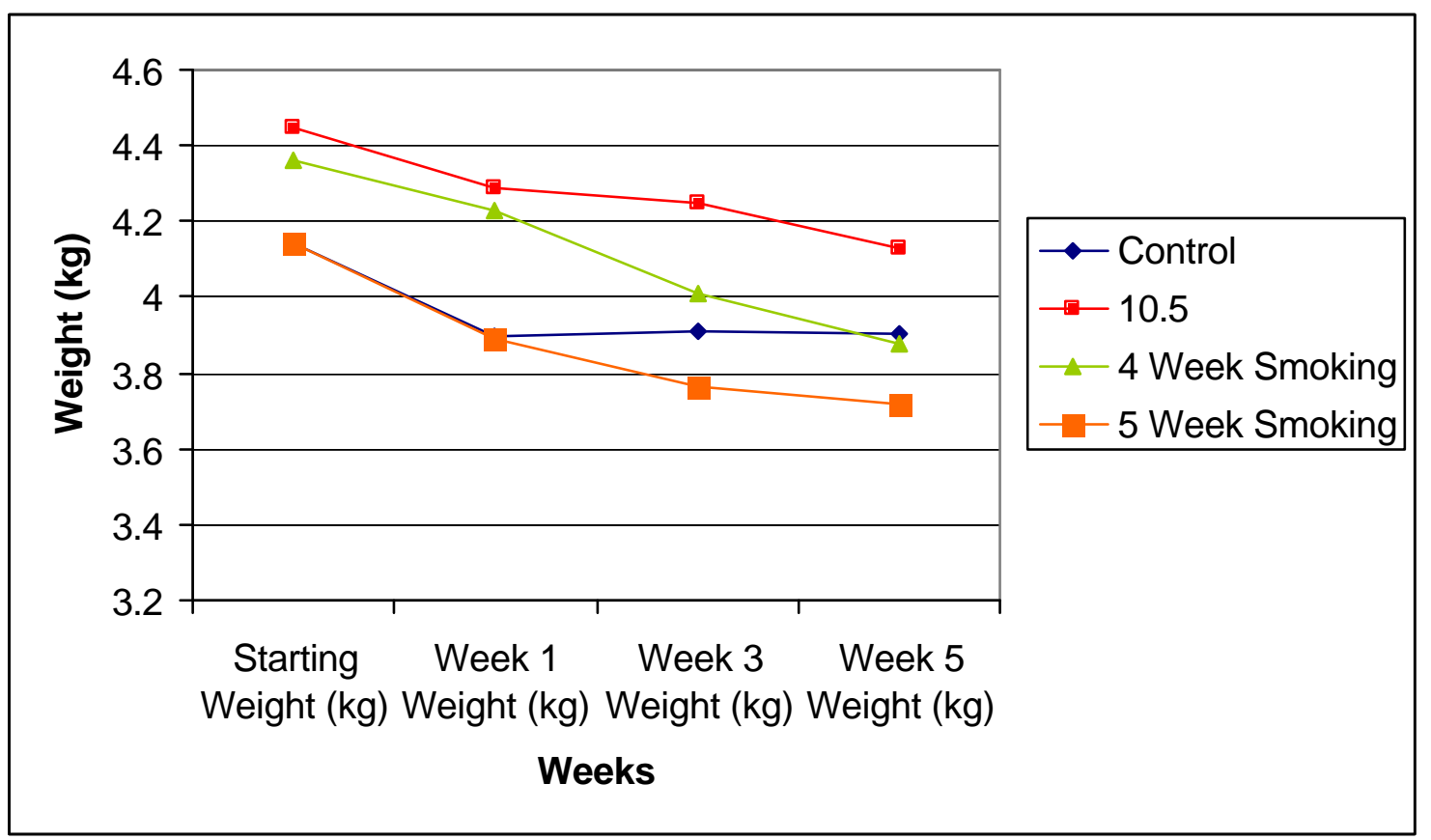

Figure 5.7 - 4: Average Weight of the rabbits during the 5-week period

Table 5.7 - 4: Values for figure 5.7-4

\begin{tabular}{|l|r|r|r|r|}
\hline Groups & $\begin{array}{l}\text { Starting } \\
\text { Weight } \\
(\mathbf{k g})\end{array}$ & $\begin{array}{l}\text { Week 1 } \\
\text { Weight } \mathbf{( k g )}\end{array}$ & $\begin{array}{l}\text { Week 3 } \\
\text { Weight } \\
(\mathbf{k g})\end{array}$ & $\begin{array}{l}\text { Week 5 } \\
\text { Weight } \\
(\mathbf{k g})\end{array}$ \\
\hline Control & 4.14 & 3.8975 & 3.908 & 3.902 \\
\hline 4 Week Smoking & 4.444444 & 4.286667 & 4.248889 & 4.128889 \\
\hline 5 Week Smoking & 4.141667 & 3.891667 & 3.763333 & 3.716667 \\
\hline Groups & $\begin{array}{l}\text { Standard } \\
\text { Deviation }\end{array}$ & $\begin{array}{l}\text { Standard } \\
\text { Deviation }\end{array}$ & $\begin{array}{l}\text { Standard } \\
\text { Deviation }\end{array}$ & $\begin{array}{l}\text { Standard } \\
\text { Deviation }\end{array}$ \\
\hline Control & 0.409878 & 0.383003 & 0.371981 & 0.309467 \\
\hline & 0.433333 & 0.402119 & 0.412839 & 0.443352 \\
\hline 4 Week Smoking & 0.424311 & 0.281668 & 0.3629 & 0.398129 \\
\hline 5 Week Smoking & 0.252936 & 0.250553 & 0.185436 & 0.168008 \\
\hline
\end{tabular}




\subsection{Fracture Toughness Values for Experiment 2}

Figure 5.8 -1 and table 5.8-1 is the fracture toughness values for each group.

Table 5.8 - 2 is the dimension for fracture toughness for each group.

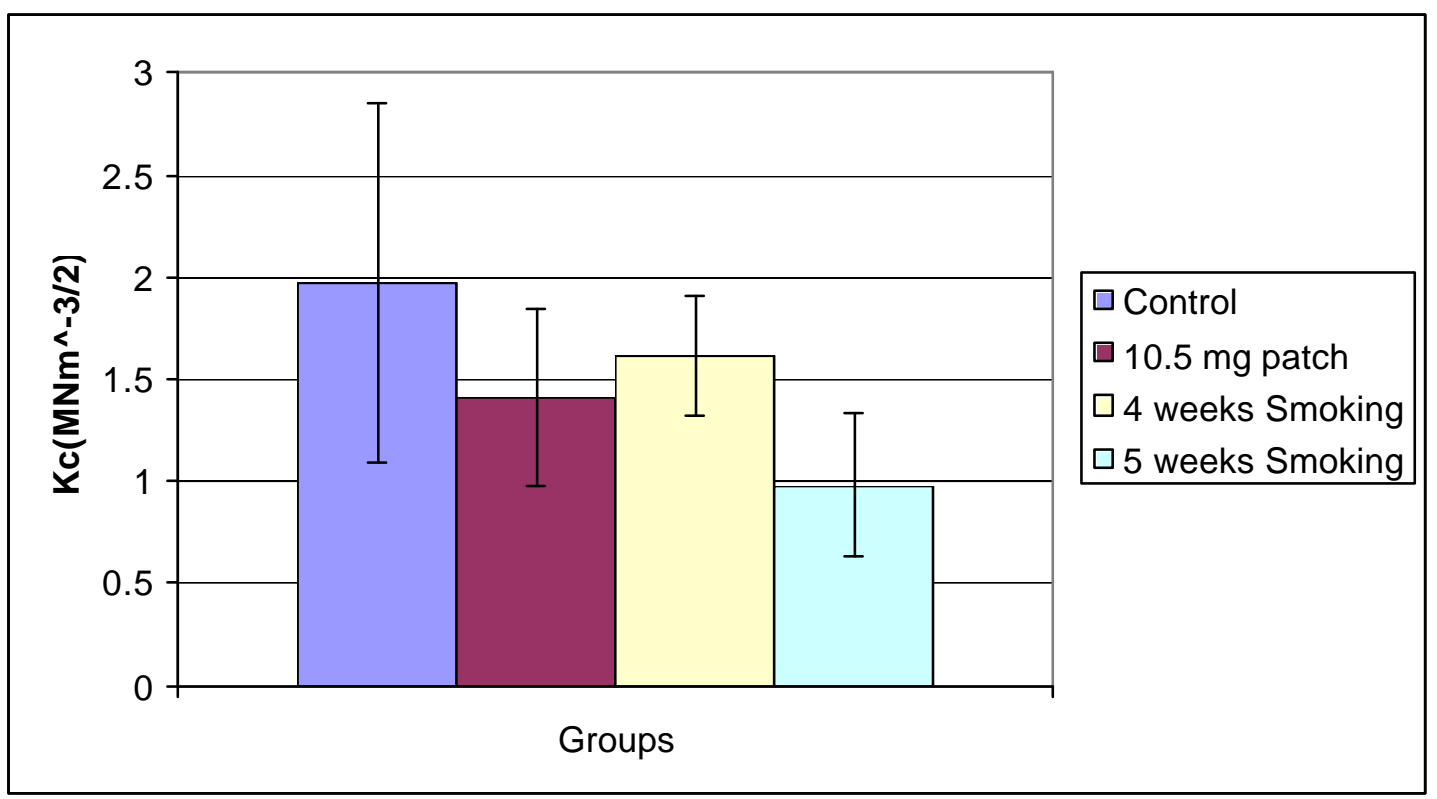

Figure 5.8 - 1: Fracture toughness values for each group

Table 5.8 -1: Values for figure 5.8 - 1 and $p$ values for each group

\begin{tabular}{|l|r|r|}
\hline group & Kc $\left(\mathbf{M N m}^{\wedge} \mathbf{- 3 / 2}\right)$ & $\begin{array}{l}\text { Standard } \\
\text { Deviation }\end{array}$ \\
\hline Control & 1.97201 & 0.883856 \\
\hline 10.5 & 1.413139 & 0.43044 \\
\hline 4 weeks Smoking & 1.610427 & 0.29439 \\
\hline 5 weeks Smoking & 0.982683 & 0.3458 \\
\hline
\end{tabular}

\begin{tabular}{|l|r|}
\hline Groups & P values \\
\hline ALL & $\mathbf{0 . 0 2 7 4}$ \\
\hline Control vs 10.5 & 0.1318 \\
\hline $\begin{array}{l}\text { Control vs 4 weeks } \\
\text { smoking }\end{array}$ & 0.3671 \\
\hline $\begin{array}{l}\text { Control vs 5 weeks } \\
\text { smoking }\end{array}$ & $\mathbf{0 . 0 3 1 7}$ \\
\hline $\begin{array}{l}10.5 \text { vs 4 weeks } \\
\text { smoking }\end{array}$ & 0.3473 \\
\hline $\begin{array}{l}10.5 \text { vs 5 weeks } \\
\text { smoking }\end{array}$ & $\mathbf{0 . 0 6 2}$ \\
\hline $\begin{array}{l}4 \text { vs 5 weeks } \\
\text { smoking }\end{array}$ & $\mathbf{0 . 0 0 6 9}$ \\
\hline
\end{tabular}


Table 5.8 - 2: Dimension for fracture toughness specimen for each group

\begin{tabular}{|l|r|r|r|r|r|}
\hline group & thickness & $\mathbf{a}$ & $\mathbf{W}$ & $\mathbf{a} / \mathbf{W}$ & \multicolumn{1}{l|}{ Load } \\
\hline Control & 0.000596 & 0.003144 & 0.005514 & 0.570547 & 6.77494 \\
\hline 10.5 & 0.000572 & 0.002753 & 0.005374 & 0.512767 & 5.928689 \\
\hline 4 week Smoking & 0.000547 & 0.002928 & 0.005452 & 0.537505 & 5.94065 \\
\hline 5 week Smoking & 0.000512 & 0.002507 & 0.005323 & 0.470753 & 3.992683 \\
\hline & Standard & Standard & Standard & Standard & Standard \\
group & Deviation & Deviation & Deviation & Deviation & Deviation \\
\hline Control & 0.000087 & 0.000357 & 0.000307 & 0.05861 & 2.220938 \\
\hline & 0.000081 & 0.000367 & 0.000222 & 0.068955 & 2.236776 \\
\hline 4 week Smoking & 0.000066 & 0.00019 & 0.000137 & 0.039237 & 1.079493 \\
\hline 5 week Smoking & 0.000057 & 0.000256 & 0.00023 & 0.043073 & 0.945486 \\
\hline
\end{tabular}




\subsection{Porosity for Experiment 2}

Figure 5.9 - 1 and Table 5.9 - 1 is the porosity for values for each group. Figure

$5.9-1$ and Table 5.9 - 1 is the average pore radius for values for each group. Figure 5.9

-2 and table $5.9-2$ is for the average pore radius of each group.

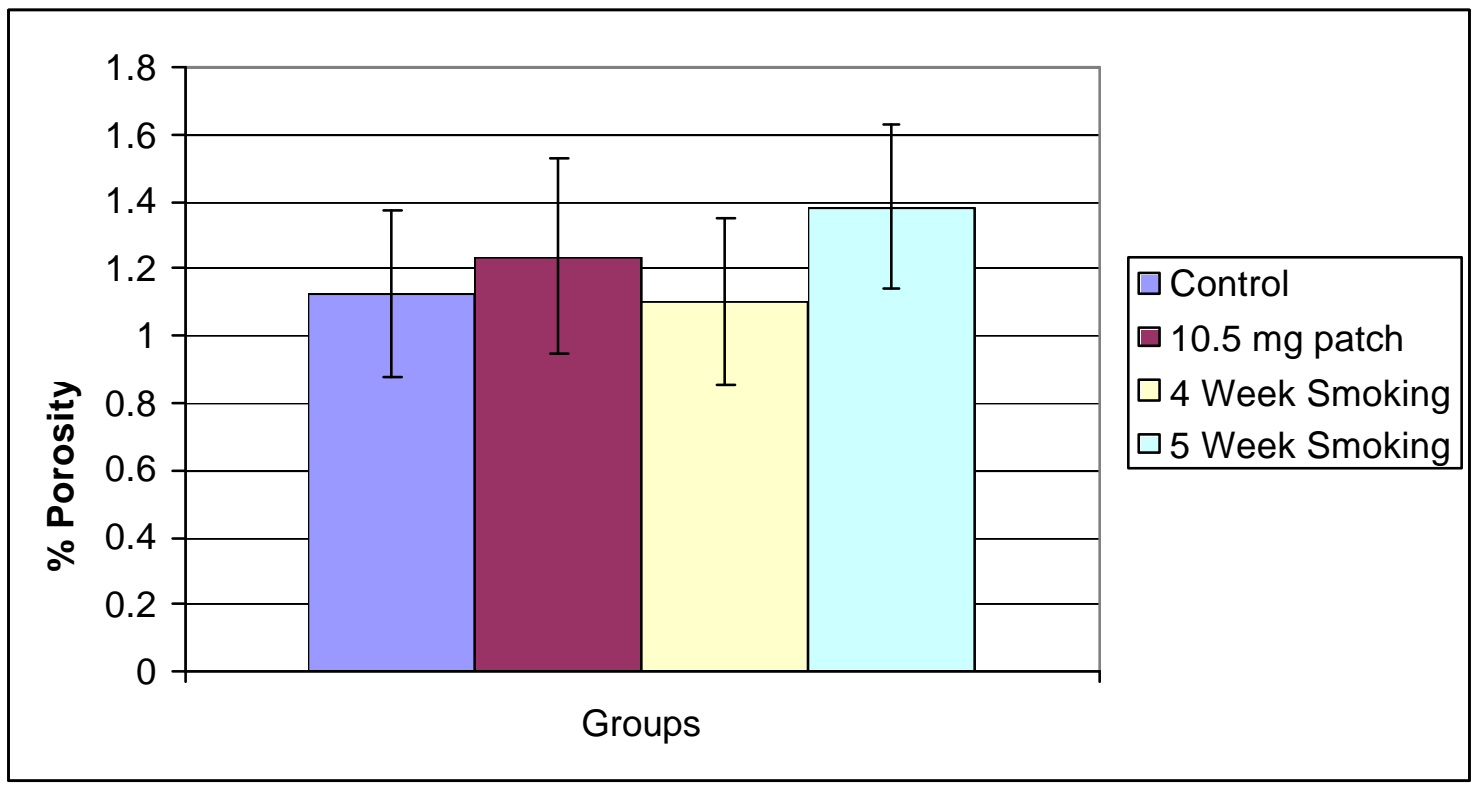

Figure 5.9 - 1: Average \% porosity for each group

Table 5.9 - 1: Values for figure 5.9 - 1 and $p$ values for each group

\begin{tabular}{|l|r|r|}
\hline Groups & \% Porosity & Standard Deviation \\
\hline Control & 1.126 & 0.2464 \\
\hline 10.5 & 1.2378 & 0.2931 \\
\hline & & \\
4 Week Smoking & 1.1033 & 0.2483 \\
\hline 5 Week Smoking & 1.3867 & 0.242 \\
\hline
\end{tabular}

\begin{tabular}{|l|r|}
\hline Groups & P values \\
\hline ALL & 0.2652 \\
\hline Control vs 10.5 & 0.4854 \\
\hline $\begin{array}{l}\text { Control vs 4 } \\
\text { weeks smoking }\end{array}$ & 0.8831 \\
\hline $\begin{array}{l}\text { Control vs 5 } \\
\text { weeks smoking }\end{array}$ & 0.1115 \\
\hline $\begin{array}{l}10.5 \text { vs 4 weeks } \\
\text { smoking }\end{array}$ & 0.3734 \\
\hline $\begin{array}{l}10.5 \text { vs 5 weeks } \\
\text { smoking }\end{array}$ & 0.3223 \\
\hline $\begin{array}{l}4 \text { vs 5 weeks } \\
\text { smoking }\end{array}$ & 0.0732 \\
\hline
\end{tabular}




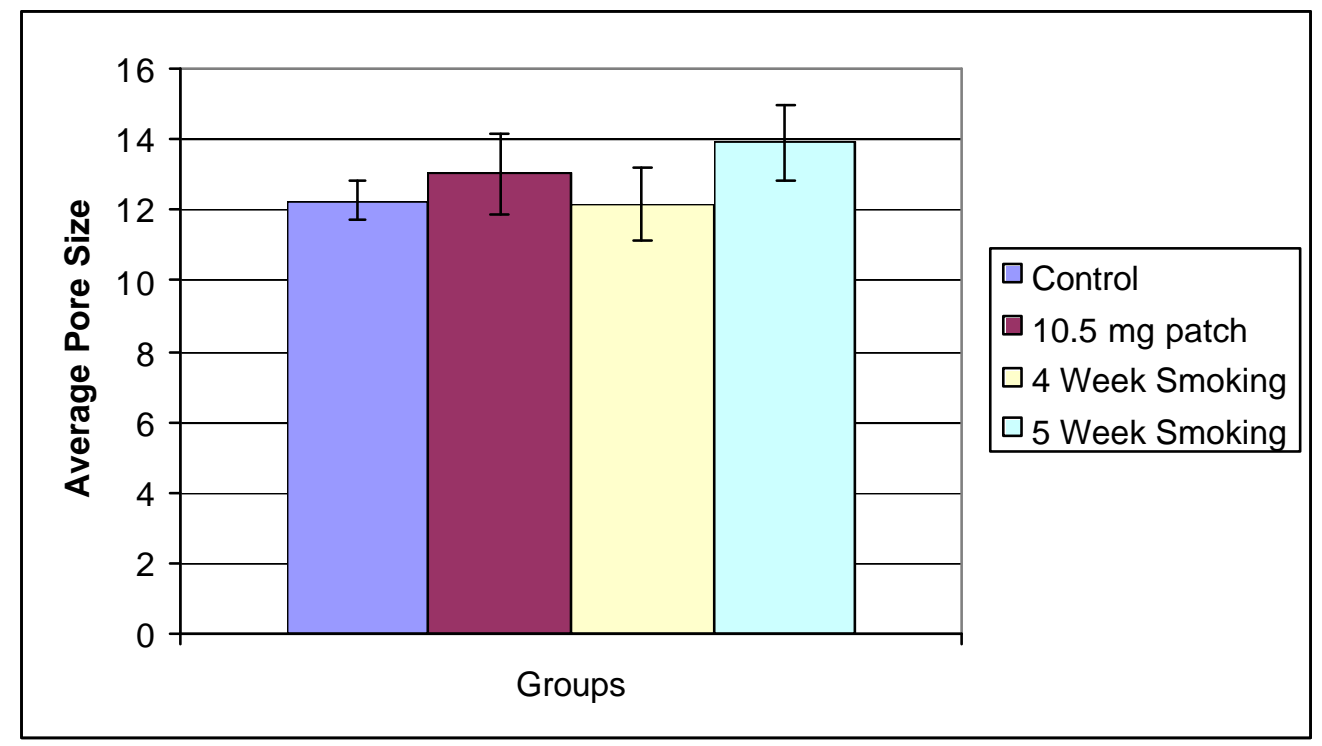

Figure 5.9 - 2: Average pore size for each group

Table 5.9 - 2: Values for figure 5.9 - 2 and $p$ values for each group

\begin{tabular}{|l|r|r|}
\hline Groups & Average Pore Size & Standard Deviation \\
\hline Control & 12.2667 & 0.570189 \\
\hline 10.5 & 13.01503 & 1.156733 \\
\hline $\begin{array}{l}\text { 4 Week } \\
\text { Smoking }\end{array}$ & 12.16335 & 0.992366 \\
\hline $\begin{array}{l}5 \text { Week } \\
\text { Smoking }\end{array}$ & 13.90523 & 1.070683 \\
\hline
\end{tabular}

\begin{tabular}{|l|r|}
\hline Groups & P values \\
\hline ALL & $\mathbf{0 . 0 2 7}$ \\
\hline Control vs 10.5 & 0.2046 \\
\hline $\begin{array}{l}\text { Control vs 4 weeks } \\
\text { smoking }\end{array}$ & 0.842 \\
\hline $\begin{array}{l}\text { Control vs 5 weeks } \\
\text { smoking }\end{array}$ & $\mathbf{0 . 0 1 3 5}$ \\
\hline $\begin{array}{l}\text { 10.5 vs 4 weeks } \\
\text { smoking }\end{array}$ & 0.1643 \\
\hline $\begin{array}{l}10.5 \text { vs 5 weeks } \\
\text { smoking }\end{array}$ & $\mathbf{0 . 0 1 5 2}$ \\
\hline $\begin{array}{l}4 \text { vs 5 weeks } \\
\text { smoking }\end{array}$ & \\
\hline
\end{tabular}




\section{Chapter 6 Discussion}

\subsection{Discussion of Results of experiment 1.}

There was significant difference seen in the nicotine levels between each group of experiment 1 . There was a close to a significance difference seen in the weight loss difference between the nicotine groups as a whole versus the control group with $\mathrm{p}=.0530$; a power analysis indicated a power of .5013 and the number of rabbits needed to determine a significant difference is 18 . A number of studies show similar results in that there was significant difference in weight loss between the nicotine groups, and control(Syversen, Nordsletten et al. 1999), but there was just as many papers showing weight gain or no significant difference between the groups (Daftari, Whitesides et al. 1994; Silcox, Daftari et al. 1995; Fung, Mendlik et al. 1998; Raikin, Landsman et al. 1998; Silcox, Boden et al. 1998; Fung, Iwaniec et al. 1999; Iwaniec, Fung et al. 2000; Iwaniec, Fung et al. 2001; Akhter, Iwaniec et al. 2003). It has been shown that people who smoke weigh less then non-smokers, and after cessation of smoking the average person gains $8 \mathrm{lbs}$ and a about 10\% gains close to 30lbs (Williamson and Madans 1991). People who weigh less have lower BMD \& increased chance of fractures(Piet 2003). Nicotine could play a part in increasing the risk of fractures by lowering the body weight and in time causing the BMD to be lower.

Rabbits administered nicotine for five weeks had no significant difference measured in any of the tests done for experiment 1 . Nicotine has been shown in other studies to have no effect on bone strength in rats for varied amounts of time, dose, age of the rat and ovariectomy or not (Fung, Mendlik et al. 1998; Fung, Iwaniec et al. 1999; Syversen, Nordsletten et al. 1999; Iwaniec, Fung et al. 2000; Iwaniec, Fung et al. 2001; 
Akhter, Iwaniec et al. 2003). In another series of tests conducted using the rabbit spine from this study, higher spine fusion results showed that $5.25 \mathrm{ng} / \mathrm{ml}$ patch had a higher fusion rate than the other groups, although the difference was not significant. The fracture toughness study showed similar, i.e. $5.25 \mathrm{ng} / \mathrm{ml}$ group had a higher, but no significant, $(\mathrm{p}=.0384)$ values compared to the control group. A power analysis indicated a power of .1226 and the number of rabbits needed to find a difference is 32 .

\subsection{Discussion of Results of Experiment 2}

The nicotine levels in experiment 2 were significantly different for each group. In the fracture toughness study, a significant difference was seen in the fracture toughness values for the 5 week smoking chamber group compared to all other groups. However, no significant difference could be found in the other groups compared to each other. There was also a close to significant difference in porosity between the control group and 5 week smoking group $(\mathrm{p}=.1115)$ and a power analysis was done on these groups and found that the power was .3514 and the number of rabbits needed in each group to determine if there is significant difference was 16 . The average pore radius was significantly different between the different groups. From this study it suggests that the nicotine has no effect on weakening bones' fracture toughness, ho wever, cigarette smoke does. Therefore something else other than nicotine may be responsible for the effect of nicotine on bone. A cigarette contains over 4,000 chemicals that maybe responsible for the smoking effect above. For example, a study done on ovariectomized rats estrogen replacement, by Lee using Polycyclic Aromatic Hydrocarbons (PAH) 7,12dimethylbenz(a)anthracene (DMBA), and Benzo-(a)pyrene (BaP) showed a decrease in both vertebral compression and three point bending test (Lee, Lee et al. 2002). 
Therefore, it is possible that PAH might be the chemical in cigarette that weakens bone. As noted previously, the 5 week smoking groups had significantly different fracture toughness value than the 4 week smoking group. The group that was exposed for 4 weeks started receiving cigarette smoke a week after the surgery and only received first and second hand smoke on the last week before sacrifice. This mean that either there is a difference between the first and second hand smoke that caused the weakening in bones or that the body recovering during the first week after the surgery absorbs more of the chemicals from cigarette smoke.

The spine fusion results have not been completed at this time. If this study shows that the 5 week smoking group has a lower fusion rate than the control and nicotine groups, then it may suggest that after a spine fusion giving the patient a nicotine patch during the first weeks of recovery may aid in the healing of the fusion and reduce the need for cigarettes at this critical time.

\subsection{Limitations and Recommendations}

There were several limitations to the project. The most significant limitation was the failure to control nicotine levels in the smoking rabbits to match those in the patch rabbits. The blood serum levels indicated significantly lower nicotine levels in the smoking group making it difficult to compare strictly on the basis of smoking versus nicotine. No measurements were made of BMD to see if the bone BMD changed in any of the nicotine or smoking groups. No histology measurements of trabecular bone were made. Also no dynamics histology was done to see if the bone-remodeling rate was affected. No other serum levels were measured in the rabbits, ie: 25 -hydroxyvitiamin D 
serum, to see if nicotine or smoking changes any of these chemical levels. In addition, no other chemical was measured for the cigarette smoking groups beside nicotine levels. Some recommendations for future studies in this field are to find out what chemical does weaken bone and investigate if there are better ways to machine fracture toughness specimens to help reduce the error due to machining. If the current spine fusion study shows that the 5 week smoking group has lower fusions rate than the controls and nicotine groups then maybe a clinical study could be completed to see if people who are given a nicotine patch after spine fusion have better fusions rate than those who are allowed to smoke right after the surgery. 


\section{Biblography}

Akhter, M. P., U. T. Iwaniec, et al. (2003). "Effects of nicotine on bone mass and strength in aged female rats." J Orthop Res 21(1): 14-9.

Albright, J. and H. Skinner (1987). The Scientific Basis of Orthopaedics. J. Albright and R. Brand. Norwalk, CT, Appleton \& Lange: 161-198.

Anderson, T. L. (1991). Fracture Mechanics. Boca Ration, CRC Press Inc.

Baron, J. A., B. Y. Farahmand, et al. (2001). "Cigarette smoking, alcohol consumption, and risk of hip fracture in women." Arch Intern Med 161(7): 983-8.

Barth, R. W., J. L. Williams, et al. (1992). "Osteon morphometry in females with femoral neck fractures." Clin Orthop(283): 178-86.

Behiri, J. C. and W. Bonfield (1989). "Orientation dependence of the fracture mechanics of cortical bone." J Biomech 22(8-9): 863-72.

Benowitz, N. L. and P. Jacob, 3rd (1984). "Daily intake of nicotine during cigarette smoking." Clin Pharmacol Ther 35(4): 499-504.

Boresi, A. P. and R. J. Schmidt (2003). Advanced Mechanics of Materials. New York, NY, John Wiley \& Sons, Inc.

Brown, C. U., Y. N. Yeni, et al. (2000). "Fracture toughness is dependent on bone location--a study of the femoral neck, femoral shaft, and the tibial shaft." $\underline{\mathbf{J}}$ Biomed Mater Res 49(3): 380-9.

Burr, D. B. and B. Martin (1989). Structure, Function, and Adaptation of Compact Bone. New York, New York, Raven Press. 
Burr, D. B., M. B. Schaffler, et al. (1988). "Composition of the cement line and its possible mechanical role as a local interface in human compact bone." $\underline{\mathrm{J} \text { Biomech }}$ 21(11): 939-45.

Cain, R. (2003). Torsional Bone Strength and Compostion of Estrogen Deficient Rabbits. Musckular Skeletal Research Center. Morgantown, West Virginia University.

Cornuz, J., D. Feskanich, et al. (1999). "Smoking, smoking cessation, and risk of hip fracture in women." Am J Med 106(3): 311-4.

Crabtree, N., N. Loveridge, et al. (2001). "Intracapsular hip fracture and the regionspecific loss of cortical bone: analysis by peripheral quantitative computed tomography." J Bone Miner Res 16(7): 1318-28.

Daftari, T. K., T. E. Whitesides, Jr., et al. (1994). "Nicotine on the revascularization of bone graft. An experimental study in rabbits." Spine 19(8): 904-11.

Daniell, H. W. (1972). "Osteoporosis and smoking." Jama 221(5): 509.

Daniell, H. W. (1976). "Osteoporosis of the slender smoker. Vertebral compression fractures and loss of metacarpal cortex in relation to postmenopausal cigarette smoking and lack of obesity." Arch Intern Med 136(3): 298-304.

Engesaeter, L. B., A. Ekeland, et al. (1978). "Methods for testing the mechanical properties of the rat femur." Acta Orthop Scand 49(6): 512-8.

France, J. and T. Norman (2002). "Intertransverse Process Arthrodesis: Efficacy of DC Stimulation in a Nicotine Exposure Model."

France, J. and T. Norman (2003). "Nicotine Delivered at Low Levels Via Patch Enhances Intertransverse Process Arthodesis." 
Friedl, K. E., J. A. Nuovo, et al. (1992). "Factors associated with stress fracture in young army women: indications for further research." Mil Med 157(7): 334-8.

Fung, Y. K., U. Iwaniec, et al. (1999). "Long-term effects of nicotine on bone and calciotropic hormones in adult female rats." Pharmacol Toxicol 85(4): 181-7.

Fung, Y. K., M. G. Mendlik, et al. (1998). "Short-term effects of nicotine on bone and calciotropic hormones in adult female rats." Pharmacol Toxicol 82(5): 243-9.

Gerdhem, P. and K. J. Obrant (2002). "Effects of cigarette-smoking on bone mass as assessed by dual-energy X- ray absorptiometry and ultrasound." Osteoporos Int 13(12): 932-6.

Heeschen, C., J. J. Jang, et al. (2001). "Nicotine stimulates angiogenesis and promotes tumor growth and atherosclerosis." Nat Med 7(7): 833-9.

Hutchison, S. and M. Reitz (1997). "Chronic Dietary L-Arginie Prevents Endothelial Dysfunction Secondary to Environmental Tobacco Smoke in Normocholestemic Rabbits." Hypertension 29: 1186-1191.

Ishikawa, S. N., G. A. Murphy, et al. (2002). "The effect of cigarette smoking on hindfoot fusions." Foot Ankle Int 23(11): 996-8.

Iwaniec, U. T., Y. K. Fung, et al. (2001). "Effects of nicotine on bone mass, turnover, and strength in adult female rats." Calcif Tissue Int 68(6): 358-64.

Iwaniec, U. T., Y. K. Fung, et al. (2000). "Effects of nicotine on bone and calciotropic hormones in growing female rats." Calcif Tissue Int 67(1): 68-74.

Lappe, J. M., M. R. Stegman, et al. (2001). "The impact of lifestyle factors on stress fractures in female Army recruits." Osteoporos Int 12(1): 35-42. 
Law, M. R. and A. K. Hackshaw (1997). "A meta-analysis of cigarette smoking, bone mineral density and risk of hip fracture: recognition of a major effect." Bmi 315(7112): 841-6.

Lee, L. L., J. S. Lee, et al. (2002). "Polycyclic aromatic hydrocarbons present in cigarette smoke cause bone loss in an ovariectomized rat model." Bone 30(6): 917-23.

Martin, B. and D. Burr (1989). Structure, Function, and Adaptation of Compact Bone. New York, NY, Raven Press.

Mow, V. C. and W. C. Hayes (1991). Basic Orthopedic Biomechanics. New York, Raven Press,Ltd.

Mukherjee, N., J. France, et al. (2003). "The Dose Dependent Effects on Nicotine on Posterior Spinal Fusion in a Rabbit Model and In Vitro Osteoblast Cell Culture."

Norman, T. (1991). "Mode I Fracture Toughness of Human Bone." Advances in Bioengineering 20: 361-364.

Ortego-Centeno, N., M. Munoz-Torres, et al. (1997). "Effect of tobacco consumption on bone mineral density in healthy young males." Calcif Tissue Int 60(6): 496-500.

Parfitt, A. M., M. K. Drezner, et al. (1987). "Bone histomorphometry: standardization of nomenclature, symbols, and units. Report of the ASBMR Histomorphometry Nomenclature Committee." J Bone Miner Res 2(6): 595-610.

Piet, G. (2003). "Falls and Fractures in Postmenopausal Women: A Review." Journal of the British Menopause Society.

Raikin, S. M., J. C. Landsman, et al. (1998). "Effect of nicotine on the rate and strength of long bone fracture healing." Clin Orthop(353): 231-7. 
Reynolds, K. L., H. A. Heckel, et al. (1994). "Cigarette smoking, physical fitness, and injuries in infantry soldiers." Am J Prev Med 10(3): 145-50.

Riebel, G. D., S. D. Boden, et al. (1995). "The effect of nicotine on incorporation of cancellous bone graft in an animal model." Spine 20(20): 2198-202.

Silcox, D. H., 3rd, S. D. Boden, et al. (1998). "Reversing the inhibitory effect of nicotine on spinal fusion using an osteoinductive protein extract." Spine 23(3): 291-6; discussion 297.

Silcox, D. H., 3rd, T. Daftari, et al. (1995). "The effect of nicotine on spinal fusion." Spine 20(14): 1549-53.

Sipe, R. V., 3rd, D. C. Buck, et al. (2000). "Nicotine administration in rabbits using Habitrol nicotine patches and nicotine nasal spray." Clin Exp Pharmacol Physiol 27(7): 480-2.

Smith, M. (2003). Bone Fracture Toughness of Estrogen Deficient Rabbits. Mechanical and Areospace Engineering. Morgantown, WV, West Virginia University: 101.

Syversen, U., L. Nordsletten, et al. (1999). "Effect of lifelong nicotine inhalation on bone mass and mechanical properties in female rat femurs." Calcif Tissue Int 65(3): 246-9.

Ueng, S. W., M. Y. Lee, et al. (1997). "Effect of intermittent cigarette smoke inhalation on tibial lengthening: experimental study on rabbits." J Trauma 42(2): 231-8.

Ueng, S. W., S. S. Lin, et al. (1999). "Bone healing of tibial lengthening is delayed by cigarette smoking: study of bone mineral density and torsional strength on rabbits." J Trauma 46(1): 110-5. 
Vashishth, D. (1991). Mode I Fracture Toughness of Human Bone. Mechanical and Areospace Engineering Department. Morgantown WV, West Virginia University.

Waldum, H. L., O. G. Nilsen, et al. (1996). "Long-term effects of inhaled nicotine." Life Sci 58(16): 1339-46.

Wang, Z. (1995). Microstructure and Microdamage of Human Bone. Mechanical and Areospace Engineering. Morgantown, WV, West Virginia University.

Ward, K. D. and R. C. Klesges (2001). "A meta-analysis of the effects of cigarette smoking on bone mineral density." Calcif Tissue Int 68(5): 259-70.

Williamson, D. F. and J. Madans (1991). "Smoking Cessation and Severity of Weight Gain in a National Cohort." The New England Journal Of Medicine 324(11): 739745.

Wing, K. J., C. G. Fisher, et al. (2000). "Stopping nicotine exposure before surgery. The effect on spinal fusion in a rabbit model." Spine 25(1): 30-4.

Wingerd, B. and G. Stein (1985). Rabbit Dissection Manual. Baltimore, MD, John Hopkins.

Yeni, Y. N. (1998). Fracture Mechanics of Human Cortical Bone: The Relationship of Geometery, Microstruc ture, and Composition with the Fracture of the Tibia, Femoral Shaft, and the Femoral Neck. Mechanical and Areospace Engineering. Morgantown, WV, West Virginia University.

Yeni, Y. N., C. U. Brown, et al. (1998). "Influence of bone composition and apparent density on fracture toughness of the human femur and tibia." Bone 22(1): 79-84.

Yeni, Y. N., C. U. Brown, et al. (1997). "The influence of bone morphology on fracture toughness of the human femur and tibia." Bone 21(5): 453-9. 
Yeni, Y. N. and T. L. Norman (2000). "Fracture toughness of human femoral neck: effect of microstructure, composition, and age." Bone 26(5): 499-504.

Zioupos, P. and J. D. Currey (1998). "Changes in the stiffness, strength, and toughness of human cortical bone with age." Bone 22(1): 57-66. 


\section{Appendix A}

Table A1-a: Weight and Nicotine measurements for every Experiment 1

\begin{tabular}{|l|r|r|l|l|}
\hline Rabbit \# & $\begin{array}{l}\text { Nicotine } \\
\text { Dose } \\
(\mathbf{m g} / \mathbf{m l})\end{array}$ & $\begin{array}{l}\text { Surugy } \\
\text { Date }\end{array}$ & $\begin{array}{l}\text { Sacurefic } \\
\text { Date }\end{array}$ & notes: \\
\hline R179 & 10.5 & $5 / 6 / 2003$ & $6 / 10 / 2003$ & paraplegia \\
\hline R181 & 10.5 & $5 / 23 / 2003$ & $6 / 27 / 2003$ & \\
\hline R187 & 10.5 & $5 / 8 / 2003$ & $6 / 12 / 2003$ & \\
\hline R188 & 10.5 & $5 / 23 / 2003$ & $6 / 27 / 2003$ & rear right leg \\
\hline R191 & 10.5 & $5 / 9 / 2003$ & $6 / 13 / 2003$ & \\
\hline R168 & 21 & $5 / 8 / 2003$ & $6 / 12 / 2003$ & \\
\hline$R 176$ & 21 & $5 / 5 / 2003$ & $6 / 10 / 2003$ & \\
\hline$R 180$ & 21 & $5 / 6 / 2003$ & $6 / 10 / 2003$ & \\
\hline$R 184$ & 21 & $5 / 7 / 2003$ & $6 / 11 / 2003$ & \\
\hline$R 192$ & 21 & $5 / 9 / 2003$ & $6 / 13 / 2003$ & \\
\hline$R 196$ & 21 & $5 / 7 / 2003$ & $6 / 11 / 2003$ & left rear leg \\
\hline$R 166$ & 5 & $5 / 22 / 2003$ & $6 / 26 / 2003$ & \\
\hline$R 174$ & 5 & $5 / 22 / 2003$ & $6 / 26 / 2003$ & \\
\hline$R 178$ & 5 & $5 / 22 / 2003$ & $6 / 26 / 2003$ & \\
\hline$R 186$ & 5 & $5 / 8 / 2003$ & $6 / 12 / 2003$ & \\
\hline$R 185$ & Control & $5 / 7 / 2003$ & $6 / 11 / 2003$ & \\
\hline$R 189$ & Control & $5 / 9 / 2003$ & $6 / 13 / 2003$ & \\
\hline$R 195$ & Control & $5 / 6 / 2003$ & $6 / 10 / 2003$ & \\
\hline
\end{tabular}


Table A1-b: Weight and Nicotine measurements for every rabbit in Experiment 1

\begin{tabular}{|l|r|r|r|r|r|r|}
\hline Rabbit \# & $\begin{array}{l}\text { Nicotine } \\
\text { Dose } \\
\text { (mg/ml) }\end{array}$ & $\begin{array}{l}\text { Starting } \\
\text { weight } \\
\text { (kg) }\end{array}$ & $\begin{array}{l}\text { Week 1 } \\
\text { weight } \\
\text { (kg) }\end{array}$ & $\begin{array}{l}\text { Week 3 } \\
\text { weight } \\
\text { (kg) }\end{array}$ & $\begin{array}{l}\text { Week 5 } \\
\text { Weight } \\
\text { (kg) }\end{array}$ & $\begin{array}{l}\text { Weight } \\
\text { Difference } \\
\text { (kg) }\end{array}$ \\
\hline R179 & 10.5 & 4.53 & 4.08 & 3.4 & 3.56 & 0.97 \\
\hline R181 & 10.5 & 4.25 & 4.08 & 3.99 & 3.85 & 0.4 \\
\hline R187 & 10.5 & 4.15 & 3.98 & 3.92 & 3.84 & 0.31 \\
\hline R188 & 10.5 & 4.51 & 4.38 & 3.91 & 3.79 & 0.72 \\
\hline R191 & 10.5 & 4.55 & 4.47 & 4.5 & 4.52 & 0.03 \\
\hline R168 & 21 & 4.04 & 3.65 & 3.4 & 3.36 & 0.68 \\
\hline R176 & 21 & 4.35 & 4.1 & 3.71 & 3.98 & 0.37 \\
\hline R180 & 21 & 4.52 & 4.49 & 4.36 & 4.26 & 0.26 \\
\hline R184 & 21 & 4.63 & 4.29 & 4.06 & 3.97 & 0.66 \\
\hline R192 & 21 & 4.24 & 4.22 & 4.1 & 3.9 & 0.34 \\
\hline R196 & 21 & 4.8 & 4.6 & 4.15 & 3.92 & 0.88 \\
\hline R166 & 5 & 3.94 & 3.9 & 3.9 & 3.77 & 0.17 \\
\hline R174 & 5 & 4.77 & 4.83 & 4.83 & 4.75 & 0.02 \\
\hline R178 & 5 & 4.37 & 4.3 & 4.12 & 4.07 & 0.3 \\
\hline R186 & 5 & 4.33 & 4.14 & 4.05 & 3.86 & 0.47 \\
\hline R185 & Control & 4.89 & & & 4.93 & -0.04 \\
\hline R189 & Control & 4.67 & & & 4.44 & 0.23 \\
\hline R195 & Control & 4.67 & 4.63 & 4.63 & 4.63 & 0.04 \\
\hline
\end{tabular}

Table A1-c: Weight and Nicotine measurements for every rabbit in Experiment 1

\begin{tabular}{|c|c|c|c|c|c|c|c|}
\hline Rabbit \# & $\begin{array}{l}\text { Nicotine } \\
\text { Dose } \\
(\mathrm{mg} / \mathrm{ml})\end{array}$ & $\begin{array}{l}\text { Nicotine } \\
\text { Full } \\
\text { (Days) }\end{array}$ & $\begin{array}{l}\text { Nicotine } \\
1 / 2 \text { one } \\
\text { patch on } \\
\text { of the } 2 \\
\text { (Days) }\end{array}$ & \begin{tabular}{|l} 
Nicotine \\
patch off \\
(days)
\end{tabular} & $\begin{array}{l}\text { Nicotine } \\
\text { Serum } \\
\text { level } 1 \\
\text { week }\end{array}$ & $\begin{array}{l}\text { Nicotine } \\
\text { Serum } \\
\text { level } 3 \\
\text { weeks }\end{array}$ & $\begin{array}{l}\text { Nicotine } \\
\text { Serum } \\
\text { level } 5 \\
\text { weeks }\end{array}$ \\
\hline $\mathrm{R} 179$ & 10.5 & 32 & 1 & 0 & 170 & 130 & 33 \\
\hline R181 & 10.5 & 34 & 1 & 0 & 94 & 140 & 57 \\
\hline R187 & 10.5 & 26 & 9 & 0 & 240 & 140 & 100 \\
\hline R188 & 10.5 & 31 & 3 & 1 & 65 & 86 & 23 \\
\hline R191 & 10.5 & 5 & 20 & 10 & 8.2 & 50 & 24 \\
\hline R168 & 21 & 26 & 7 & 2 & 170 & 160 & 70 \\
\hline $\mathrm{R} 176$ & 21 & 22 & 2 & 12 & 260 & 7.7 & 76 \\
\hline $\mathrm{R} 180$ & 21 & 28 & 3 & 0 & 190 & 290 & 110 \\
\hline R184 & 21 & 26 & 4 & 5 & 380 & 19 & 160 \\
\hline R192 & 21 & 20 & 9 & 4 & 290 & 59 & 200 \\
\hline R196 & 21 & 26 & 1 & 7 & 72 & 13 & 65 \\
\hline R166 & 5 & 6 & $x$ & 27 & 0 & 16 & 0 \\
\hline R174 & 5 & 15 & $x$ & 19 & 7 & 9.2 & 6.5 \\
\hline R178 & 5 & 16 & $x$ & 18 & 0 & 21 & 12 \\
\hline R186 & 5 & 3 & $x$ & 30 & 0 & 7.7 & 10 \\
\hline R185 & Control & $x$ & $x$ & $x$ & 0 & 0 & 0 \\
\hline R189 & Control & $x$ & $x$ & $x$ & 0 & 0 & 0 \\
\hline R195 & Control & $x$ & $x$ & $x$ & 0 & 0 & 0 \\
\hline
\end{tabular}


Table A2-a: Fracture toughness measurement and values for each rabbit in Experiment 1

\begin{tabular}{|l|r|r|r|r|r|r|}
\hline Rabbit \# & $\begin{array}{l}\text { Nicotine } \\
\text { Dose } \\
(\mathbf{m g} / \mathbf{m l})\end{array}$ & $\begin{array}{l}\text { Nicotine } \\
\text { Dose } \\
(\mathbf{m g} / \mathbf{m l})\end{array}$ & $\begin{array}{l}\text { thickness } \\
(\mathbf{m})\end{array}$ & $\mathbf{a}(\mathbf{m})$ & $\mathbf{W}(\mathbf{m})$ & $\mathbf{a} / \mathbf{W}$ \\
\hline $\mathrm{R} 179$ & 10.5 & 10.5 & 0.00054 & 0.00189 & 0.00476 & 0.397059 \\
\hline $\mathrm{R} 181$ & 10.5 & 10.5 & 0.00055 & 0.00268 & 0.0053 & 0.50566 \\
\hline $\mathrm{R} 187$ & 10.5 & 10.5 & 0.00058 & 0.0029 & 0.0048 & 0.604167 \\
\hline $\mathrm{R} 188$ & 10.5 & 10.5 & 0.00059 & 0.00252 & 0.005425 & 0.464516 \\
\hline $\mathrm{R} 191$ & 10.5 & 10.5 & 0.00076 & 0.00255 & 0.00545 & 0.46789 \\
\hline $\mathrm{R} 168$ & 21 & 21 & 0.00062 & 0.00242 & 0.0049 & 0.493878 \\
\hline $\mathrm{R} 176$ & 21 & 21 & 0.00054 & 0.0027 & 0.0055 & 0.490909 \\
\hline $\mathrm{R} 180$ & 21 & 21 & 0.00069 & 0.00263 & 0.00554 & 0.474729 \\
\hline $\mathrm{R} 184$ & 21 & 21 & 0.00042 & 0.00226 & 0.00496 & 0.455645 \\
\hline $\mathrm{R} 192$ & 21 & 21 & 0.00059 & 0.00266 & 0.005645 & 0.471213 \\
\hline $\mathrm{R} 196$ & 21 & 21 & 0.00067 & 0.00288 & 0.00565 & 0.509735 \\
\hline $\mathrm{R} 166$ & 5 & 5 & 0.00057 & 0.0025 & 0.0055 & 0.454545 \\
\hline $\mathrm{R} 174$ & 5 & 5 & 0.00047 & 0.0028 & 0.005 & 0.56 \\
\hline $\mathrm{R} 178$ & 5 & 5 & 0.00055 & 0.00265 & 0.005415 & 0.489381 \\
\hline $\mathrm{R} 186$ & 5 & 5 & 0.00054 & 0.00244 & 0.00528 & 0.462121 \\
\hline $\mathrm{R} 185$ & Control & Control & 0.00052 & 0.0026 & 0.005 & 0.52 \\
\hline $\mathrm{R} 189$ & Control & Control & 0.00069 & 0.00304 & 0.00538 & 0.565056 \\
\hline $\mathrm{R} 195$ & Control & Control & 0.00064 & 0.00246 & 0.00523 & 0.470363 \\
\hline
\end{tabular}

Table A2-b: Fracture toughness measurement and values for each rabbit in Experiment 1

\begin{tabular}{|l|r|r|r|r|r|}
\hline Rabbit \# & $\begin{array}{l}\text { Nicotine } \\
\text { Dose } \\
\text { (mg/ml) }\end{array}$ & $\mathbf{f}(\mathbf{a} / \mathbf{W})$ & $\begin{array}{l}\text { Max } \\
\text { Load } \mathbf{( N )}\end{array}$ & $\begin{array}{l}\text { Kc } \\
(\mathbf{M N m} \\
\mathbf{3} / \mathbf{2})\end{array}$ & $\begin{array}{l}\text { Complinace } \\
\text { Slope Inverse }\end{array}$ \\
\hline R179 & 10.5 & 7.270231 & 6.3468 & 1.238528 & 2.247696 \\
\hline R181 & 10.5 & 9.767915 & 6.5204 & 1.590653 & 2.51067 \\
\hline R187 & 10.5 & 13.76891 & 2.41 & 0.825787 & 4.2123 \\
\hline R188 & 10.5 & 8.674538 & 6.4935 & 1.296204 & 2.392344 \\
\hline R191 & 10.5 & 8.75609 & 6.9306 & 1.081606 & 2.423655 \\
\hline R168 & 21 & 9.430979 & 5.9247 & 1.287459 & 3.101737 \\
\hline R176 & 21 & 9.34934 & 7.54673 & 1.761833 & 2.797985 \\
\hline R180 & 21 & 8.925424 & 10.0232 & 1.741932 & 1.948938 \\
\hline R184 & 21 & 8.466053 & 4.4038 & 1.260429 & 3.462604 \\
\hline R192 & 21 & 8.837679 & 6.4785 & 1.291602 & 3.128911 \\
\hline R196 & 21 & 9.889565 & 6.1702 & 1.211651 & 2.3912 \\
\hline R166 & 5 & 8.440778 & 10.6249 & 2.121539 & 2.065262 \\
\hline R174 & 5 & 11.65799 & 3.2752 & 1.14889 & 3.648304 \\
\hline R178 & 5 & 9.307811 & 8.9603 & 2.060669 & 2.49501 \\
\hline R186 & 5 & 8.617418 & 5.4756 & 1.202536 & 2.514458 \\
\hline R185 & Control & 10.20866 & 4.5296 & 1.257593 & 3.749531 \\
\hline R189 & Control & 11.86883 & 7.0713 & 1.658315 & 2.464876 \\
\hline R195 & Control & 8.816687 & 5.0804 & 0.967771 & 2.62743 \\
\hline
\end{tabular}


Table A3-a: Bending Stress measurements for each rabbit in Experiment 1

\begin{tabular}{|l|r|r|r|r|r|r|}
\hline Rabbit \# & $\begin{array}{l}\text { Nicotine } \\
\text { Dose } \\
(\mathbf{m g} / \mathbf{m l})\end{array}$ & $\begin{array}{l}\text { max } \\
\text { load (N) }\end{array}$ & $\begin{array}{l}\text { max } \\
\text { deflections } \\
(\mathbf{m m})\end{array}$ & $\begin{array}{l}\text { bo } \\
\text { diameter } \\
\text { short } \\
\text { outside } \\
\text { mm }\end{array}$ & $\begin{array}{l}\text { bo/2 } \\
\text { radius } \\
\text { mm }\end{array}$ & $\begin{array}{l}\text { bi } \\
\text { diameter } \\
\text { short } \\
\text { inside } \\
\text { mm }\end{array}$ \\
\hline R179 & 10.5 & 370.67 & -1.3798 & 7.182 & 3.591 & 5.164 \\
\hline R181 & 10.5 & 305.91 & -0.9302 & 7.036 & 3.518 & 4.855 \\
\hline R187 & 10.5 & 310.41 & -0.8713 & 7.2 & 3.6 & 5.455 \\
\hline R188 & 10.5 & 343.22 & -1.1992 & 6.727 & 3.3635 & 4.709 \\
\hline R191 & 10.5 & 297 & -1.0108 & 6.764 & 3.382 & 4.873 \\
\hline R168 & 21 & 320.42 & -1.1914 & 6.964 & 3.482 & 4.8 \\
\hline R176 & 21 & 340.38 & -1.0116 & 6.527 & 3.2635 & 4.345 \\
\hline R180 & 21 & 333.98 & -1.5604 & 7.945 & 3.9725 & 6.327 \\
\hline R184 & 21 & 337.53 & -1.1759 & 7.291 & 3.6455 & 5.491 \\
\hline R192 & 21 & 300.46 & -1.179 & 7.073 & 3.5365 & 5.291 \\
\hline R196 & 21 & 503.93 & -1.5968 & 7.218 & 3.609 & 5 \\
\hline R166 & 5 & 377.73 & -1.3061 & 7.236 & 3.618 & 5.236 \\
\hline R174 & 5 & 429.31 & -1.2333 & 7.491 & 3.7455 & 5.436 \\
\hline R178 & 5 & 367.63 & -1.0844 & 6.745 & 3.3725 & 4.655 \\
\hline R186 & 5 & 222.24 & -0.217 & 7.327 & 3.6635 & 4.873 \\
\hline R185 & Control & 299.32 & -0.9333 & 7.509 & 3.7545 & 5.473 \\
\hline R189 & Control & 284.1 & -1.0961 & 7.618 & 3.809 & 5.855 \\
\hline R195 & Control & 413.24 & -1.0658 & 7.382 & 3.691 & 5.091 \\
\hline
\end{tabular}

Table A3-b: Bending Stress measurements for each rabbit in Experiment 1

\begin{tabular}{|c|c|c|c|c|c|c|}
\hline Rabbit \# & \begin{tabular}{|l|} 
Nicotine \\
Dose \\
$(\mathrm{mg} / \mathrm{ml})$ \\
\end{tabular} & $\begin{array}{l}\text { thickness } \\
1 \mathrm{~mm}\end{array}$ & $\begin{array}{l}\text { thickness } \\
2 \mathrm{~mm}\end{array}$ & $\begin{array}{l}\text { thickness } \\
3 \mathrm{~mm}\end{array}$ & $\begin{array}{l}\text { thickness } \\
4 \mathrm{~mm}\end{array}$ & $\begin{array}{l}\text { Average } \\
\mathrm{mm}\end{array}$ \\
\hline R179 & 10.5 & 1.255 & 1.091 & 1.255 & 0.891 & 1.123 \\
\hline R181 & 10.5 & 1.238 & 1.164 & 1.309 & 1.018 & 1.18225 \\
\hline R187 & 10.5 & 0.891 & 0.855 & 1.055 & 0.855 & 0.914 \\
\hline R188 & 10.5 & 1.491 & 1.164 & 1.091 & 0.855 & 1.15025 \\
\hline R191 & 10.5 & 1.218 & 1 & 1.073 & 0.873 & 1.041 \\
\hline R168 & 21 & 1.418 & 1.018 & 1.345 & 1.145 & 1.2315 \\
\hline R176 & 21 & 1.073 & 1 & 1.364 & 1.145 & 1.1455 \\
\hline R180 & 21 & 1.073 & 0.636 & 1.091 & 0.964 & 0.941 \\
\hline R184 & 21 & 1.018 & 0.891 & 1.236 & 0.945 & 1.0225 \\
\hline R192 & 21 & 1.127 & 0.945 & 1.127 & 0.836 & 1.00875 \\
\hline R196 & 21 & 1.327 & 1.109 & 1.2 & 1.091 & 1.18175 \\
\hline R166 & 5 & 1.036 & 1 & 1.273 & 0.982 & 1.07275 \\
\hline R174 & 5 & 1.164 & 0.982 & 1.218 & 1.055 & 1.10475 \\
\hline R178 & 5 & 1.182 & 1.109 & 1.055 & 1 & 1.0865 \\
\hline R186 & 5 & 1.364 & 1.291 & 1.127 & 1.164 & 1.2365 \\
\hline R185 & Control & 1.091 & 0.982 & 1.473 & 0.982 & 1.132 \\
\hline \begin{tabular}{|l|} 
R189 \\
\end{tabular} & Control & 1.091 & 0.764 & 1.109 & 0.927 & 0.97275 \\
\hline R195 & Control & 1.291 & 1.273 & 0.909 & 1.018 & 1.12275 \\
\hline
\end{tabular}


Table A3-c: Bending Stress measurements for each rabbit in Experiment 1

\begin{tabular}{|l|r|r|r|r|r|r|r|r|}
\hline Rabbit \# & $\begin{array}{l}\text { Nicotine } \\
\text { Dose } \\
\text { (mg/ml) }\end{array}$ & $\begin{array}{l}\text { ao } \\
\text { diameter } \\
\text { long } \\
\text { outside } \\
\text { mm }\end{array}$ & $\begin{array}{l}\text { ao/2 } \\
\text { radius } \\
\text { mm }\end{array}$ & $\begin{array}{l}\text { ai } \\
\text { diameter } \\
\text { long } \\
\text { inside } \\
\text { mm }\end{array}$ & $\begin{array}{l}\text { Moment } \\
\mathbf{N}^{*} \mathbf{m}\end{array}$ & $\begin{array}{l}\text { Moment } \\
\text { of Inerta } \\
\text { hollow } \\
\text { ellipsce } \\
\mathbf{m}^{\wedge} \mathbf{4}\end{array}$ & $\begin{array}{l}\text { Bending } \\
\text { Stress pa }\end{array}$ & $\begin{array}{l}\text { bending } \\
\text { Stress in } \\
\text { Mpa }\end{array}$ \\
\hline R179 & 10.5 & 10.255 & 5.1275 & 7.764 & 11.49077 & $5.57 \mathrm{E}-10$ & $2.96 \mathrm{E}+08$ & 296.4226 \\
\hline R181 & 10.5 & 9.012 & 4.506 & 6.555 & 9.48321 & $4.83 \mathrm{E}-10$ & $2.76 \mathrm{E}+08$ & 276.1243 \\
\hline R187 & 10.5 & 9.564 & 4.782 & 7.6 & 9.62271 & $4.65 \mathrm{E}-10$ & $2.98 \mathrm{E}+08$ & 297.7136 \\
\hline R188 & 10.5 & 9.673 & 4.8365 & 7.164 & 10.63982 & $4.53 \mathrm{E}-10$ & $3.16 \mathrm{E}+08$ & 316.2677 \\
\hline R191 & 10.5 & 9.127 & 4.5635 & 6.855 & 9.207 & $4.13 \mathrm{E}-10$ & $3.02 \mathrm{E}+08$ & 301.8623 \\
\hline R168 & 21 & 9.455 & 4.7275 & 6.673 & 9.93302 & $5.02 \mathrm{E}-10$ & $2.76 \mathrm{E}+08$ & 275.6943 \\
\hline R176 & 21 & 10.091 & 5.0455 & 7.636 & 10.55178 & $4.35 \mathrm{E}-10$ & $3.17 \mathrm{E}+08$ & 316.9927 \\
\hline R180 & 21 & 10.855 & 5.4275 & 8.673 & 10.35338 & $6.76 \mathrm{E}-10$ & $2.43 \mathrm{E}+08$ & 243.2799 \\
\hline R184 & 21 & 9.509 & 4.7545 & 7.309 & 10.46343 & $5.12 \mathrm{E}-10$ & $2.98 \mathrm{E}+08$ & 297.9684 \\
\hline R192 & 21 & 9.818 & 4.909 & 7.564 & 9.31426 & $4.84 \mathrm{E}-10$ & $2.72 \mathrm{E}+08$ & 272.1037 \\
\hline R196 & 21 & 9.982 & 4.991 & 7.527 & 15.62183 & $5.66 \mathrm{E}-10$ & $3.98 \mathrm{E}+08$ & 398.4963 \\
\hline R166 & 5 & 9.164 & 4.582 & 6.818 & 11.70963 & $5 \mathrm{E}-10$ & $3.39 \mathrm{E}+08$ & 338.962 \\
\hline R174 & 5 & 10.055 & 5.0275 & 7.746 & 13.30861 & $6.03 \mathrm{E}-10$ & $3.31 \mathrm{E}+08$ & 330.682 \\
\hline R178 & 5 & 8.727 & 4.3635 & 6.509 & 11.39653 & $4.03 \mathrm{E}-10$ & $3.82 \mathrm{E}+08$ & 381.6397 \\
\hline R186 & 5 & 9.436 & 4.718 & 6.982 & 6.88944 & $5.72 \mathrm{E}-10$ & $1.76 \mathrm{E}+08$ & 176.3703 \\
\hline R185 & Control & 10.073 & 5.0365 & 7.6 & 9.27892 & $6.16 \mathrm{E}-10$ & $2.26 \mathrm{E}+08$ & 226.1583 \\
\hline R189 & Control & 9.746 & 4.873 & 7.618 & 8.8071 & $5.66 \mathrm{E}-10$ & $2.37 \mathrm{E}+08$ & 236.8848 \\
\hline R195 & Control & 9.782 & 4.891 & 7.6 & 12.81044 & $5.72 \mathrm{E}-10$ & $3.31 \mathrm{E}+08$ & 330.5925 \\
\hline & & & & & & & & \\
\hline
\end{tabular}

Table A4-a: Femoral Neck Load for each measurement in Experiment 1

\begin{tabular}{|l|r|r|}
\hline Rabbit \# & $\begin{array}{l}\text { Nicotine } \\
\text { Dose } \\
\text { (mg/ml) }\end{array}$ & $\begin{array}{l}\text { Ultimate } \\
\text { Load (N) } \\
\text { Fx neck }\end{array}$ \\
\hline R179 & 10.5 & 762.2787 \\
\hline R181 & 10.5 & 1053.348 \\
\hline R187 & 10.5 & 1167.121 \\
\hline R188 & 10.5 & 1226.378 \\
\hline R191 & 10.5 & 1097.909 \\
\hline R168 & 21 & 1032.964 \\
\hline R176 & 21 & 1173.284 \\
\hline R180 & 21 & 1251.265 \\
\hline R184 & 21 & 1053.111 \\
\hline R192 & 21 & 1100.99 \\
\hline R196 & 21 & 1379.497 \\
\hline R166 & 5 & 1059.037 \\
\hline R174 & 5 & 1007.365 \\
\hline R178 & 5 & 1169.254 \\
\hline R186 & 5 & 938.3898 \\
\hline R185 & Control & 1046 \\
\hline R189 & Control & 989.3506 \\
\hline R195 & Control & 986.5063 \\
\hline
\end{tabular}


Table A5-a: Shear Stress Measurements for each rabbit in Experiment 1

\begin{tabular}{|l|r|l|r|r|r|r|r|}
\hline Rabbit \# & $\begin{array}{l}\text { Nicotine } \\
\text { Dose } \\
\text { (mg/ml) }\end{array}$ & $\begin{array}{l}\text { bo } \\
\text { diameter } \\
\text { short } \\
\text { outside } \\
\text { mm }\end{array}$ & bo radius & $\begin{array}{l}\text { bi } \\
\text { diameter } \\
\text { short } \\
\text { inside } \\
\text { mm }\end{array}$ & $\begin{array}{l}\text { ao } \\
\text { diameter } \\
\text { long } \\
\text { outside } \\
\text { mm }\end{array}$ & ao radius & $\begin{array}{l}\text { ai } \\
\text { diameter } \\
\text { long } \\
\text { inside } \\
\text { mm }\end{array}$ \\
\hline R179 & 10.5 & 5.203 & 2.6015 & 3.035 & 7.355 & 3.6775 & 4.802 \\
\hline R181 & 10.5 & 5.018 & 2.509 & 2.982 & 6.75 & 3.375 & 4.5 \\
\hline R187 & 10.5 & 4.875 & 2.4375 & 2.786 & 7.304 & 3.652 & 4.964 \\
\hline R188 & 10.5 & 5.571 & 2.7855 & 3.161 & 6.786 & 3.393 & 4.304 \\
\hline R191 & 10.5 & 5.036 & 2.518 & 3.321 & 6.911 & 3.4555 & 4.964 \\
\hline R168 & 21 & 5.018 & 2.509 & 2.607 & 6.982 & 3.491 & 4.5 \\
\hline R176 & 21 & 5.25 & 2.625 & 3.232 & 7.339 & 3.6695 & 5.179 \\
\hline R180 & 21 & 5.696 & 2.848 & 3.339 & 7.804 & 3.902 & 5.446 \\
\hline R184 & 21 & 5.161 & 2.5805 & 3.268 & 7.768 & 3.884 & 5.929 \\
\hline R192 & 21 & 5.054 & 2.527 & 3.018 & 7.196 & 3.598 & 4.946 \\
\hline R196 & 21 & 5.411 & 2.7055 & 2.946 & 7.143 & 3.5715 & 4.536 \\
\hline R166 & 5 & 5.63 & 2.815 & 3.256 & 7.912 & 3.956 & 4.804 \\
\hline R174 & 5 & 5.224 & 2.612 & 3.172 & 7.724 & 3.862 & 5.259 \\
\hline R178 & 5 & 5.138 & 2.569 & 3.121 & 6.983 & 3.4915 & 4.5 \\
\hline R186 & 5 & 5.086 & 2.543 & 3.564 & 7.103 & 3.5515 & 5.259 \\
\hline R185 & Control & 5.138 & 2.569 & 3.069 & 8.052 & 4.026 & 5.586 \\
\hline R189 & Control & 5.672 & 2.836 & 3.793 & 7.397 & 3.6985 & 5.293 \\
\hline R195 & Control & 5.224 & 2.612 & 3.172 & 7.207 & 3.6035 & 4.845 \\
\hline
\end{tabular}

Table A5-b: Shear Stress Measurements for each rabbit in Experiment 1

\begin{tabular}{|c|c|c|c|c|c|c|}
\hline Rabbit \# & \begin{tabular}{|l} 
Nicotine \\
Dose \\
$(\mathrm{mg} / \mathrm{ml})$ \\
\end{tabular} & \begin{tabular}{|l|} 
thickness \\
$1 \mathrm{~mm}$
\end{tabular} & $\begin{array}{l}\text { thickness } \\
2 \mathrm{~mm}\end{array}$ & \begin{tabular}{|l|} 
thickness \\
$3 \mathrm{~mm}$
\end{tabular} & \begin{tabular}{|l} 
thickness \\
$4 \mathrm{~mm}$
\end{tabular} & $\begin{array}{l}\text { Average } \\
\mathrm{mm}\end{array}$ \\
\hline R179 & 10.5 & 1.297 & 1.131 & 1.231 & 0.995 & 1.1635 \\
\hline R181 & 10.5 & 1.054 & 1 & 1.214 & 1.018 & 1.0715 \\
\hline R187 & 10.5 & 1.036 & 1.018 & 1.286 & 1 & 1.085 \\
\hline R188 & 10.5 & 1.214 & 1.089 & 1.304 & 1.25 & 1.21425 \\
\hline R191 & 10.5 & 1.036 & 0.839 & 0.964 & 0.911 & 0.9375 \\
\hline R168 & 21 & 1.232 & 1.161 & 1.286 & 1.286 & 1.24125 \\
\hline R176 & 21 & 1.268 & 1.018 & 0.929 & 0.982 & 1.04925 \\
\hline R180 & 21 & 1.161 & 1.214 & 1.25 & 1.107 & 1.183 \\
\hline R184 & 21 & 0.893 & 0.946 & 1 & 0.947 & 0.9465 \\
\hline R192 & 21 & 1.179 & 0.982 & 1.107 & 1.036 & 1.076 \\
\hline R196 & 21 & 1.304 & 1.286 & 1.357 & 1.143 & 1.2725 \\
\hline R166 & 5 & 1.643 & 1.05 & 1.488 & 1.382 & 1.39075 \\
\hline R174 & 5 & 1.172 & 1.017 & 1.31 & 1.017 & 1.129 \\
\hline R178 & 5 & 1.276 & 1.017 & 1.224 & 1.052 & 1.14225 \\
\hline R186 & 5 & 1 & 0.759 & 0.879 & 0.828 & 0.8665 \\
\hline R185 & Control & 1.224 & 1 & 1.207 & 1.103 & 1.1335 \\
\hline R189 & Control & 1.069 & 0.948 & 1.052 & 0.948 & 1.00425 \\
\hline R195 & Control & 1.14 & 0.864 & 1.053 & 0.985 & 1.0105 \\
\hline
\end{tabular}


Table A5-c: Shear Stress Measurements for each rabbit in Experiment 1

\begin{tabular}{|l|l|l|l|l|r|}
\hline Rabbit \# & $\begin{array}{l}\text { Nicotine } \\
\text { Dose } \\
(\mathbf{m g} / \mathbf{m l})\end{array}$ & $\begin{array}{l}\text { Torsion } \\
\mathbf{N}^{*} \mathbf{m}\end{array}$ & $\begin{array}{l}\text { Polar } \\
\text { Moment } \\
\text { of Inerta } \\
\text { hollow } \\
\text { ellipsce } \\
\text { (m^4) }\end{array}$ & $\begin{array}{l}\text { Shear } \\
\text { Stress } \\
\text { (pa) }\end{array}$ & $\begin{array}{l}\text { Shear } \\
\text { Stress } \\
\text { (Mpa) }\end{array}$ \\
\hline R179 & 10.5 & 2.8476 & $5.15 \mathrm{E}-10$ & 57580751 & 57.58075 \\
\hline R181 & 10.5 & 3.2201 & $3.94 \mathrm{E}-10$ & 82065987 & 82.06599 \\
\hline R187 & 10.5 & 4.4264 & $4.47 \mathrm{E}-10$ & 96481733 & 96.48173 \\
\hline R188 & 10.5 & 3.8562 & $4.95 \mathrm{E}-10$ & 86869665 & 86.86966 \\
\hline R191 & 10.5 & 3.8331 & $3.89 \mathrm{E}-10$ & 99195465 & 99.19547 \\
\hline R168 & 21 & 3.7639 & $4.49 \mathrm{E}-10$ & 84163816 & 84.16382 \\
\hline R176 & 21 & 4.2154 & $4.95 \mathrm{E}-10$ & 89466604 & 89.4666 \\
\hline R180 & 21 & 3.8859 & $6.7 \mathrm{E}-10$ & 66055913 & 66.05591 \\
\hline R184 & 21 & 3.4343 & $5.14 \mathrm{E}-10$ & 68927559 & 68.92756 \\
\hline R192 & 21 & 3.2332 & $4.55 \mathrm{E}-10$ & 71850566 & 71.85057 \\
\hline R196 & 21 & 4.3729 & $5.33 \mathrm{E}-10$ & 88711294 & 88.71129 \\
\hline R166 & 5 & 3.0783 & $7.26 \mathrm{E}-10$ & 47747727 & 47.74773 \\
\hline R174 & 5 & 3.609 & $5.66 \mathrm{E}-10$ & 66646347 & 66.64635 \\
\hline R178 & 5 & 3.7507 & $4.5 \mathrm{E}-10$ & 85660025 & 85.66003 \\
\hline R186 & 5 & 2.4521 & $4 \mathrm{E}-10$ & 62409400 & 62.4094 \\
\hline R185 & Control & 4.2814 & $6.05 \mathrm{E}-10$ & 72708872 & 72.70887 \\
\hline R189 & Control & 4.5648 & $5.51 \mathrm{E}-10$ & 93944608 & 93.94461 \\
\hline R195 & Control & 3.2992 & $4.65 \mathrm{E}-10$ & 74203707 & 74.20371 \\
\hline
\end{tabular}

Table A6-a: Volume 1 Measurements for each rabbit in Experiment 1

\begin{tabular}{|l|l|r|r|r|r|}
\hline & \multicolumn{3}{|l|}{ Volume 1 } & & \\
\hline & $\begin{array}{l}\text { Nicotine } \\
\text { Dose } \\
\text { Rabbit \# } \\
\text { (mg/ml) }\end{array}$ & W & L & H & V1 \\
\hline R179 & 10.5 & 0.54 & 2.53 & 6.53 & 7.224826 \\
\hline R181 & 10.5 & 0.5 & 2.542 & 6.79 & 7.059294 \\
\hline R187 & 10.5 & 0.5 & 2.41 & 6.68 & 6.478604 \\
\hline R188 & 10.5 & 0.58 & 2.44 & 6.75 & 7.730476 \\
\hline R191 & 10.5 & 0.83 & 2.13 & 6.6 & 9.060618 \\
\hline R168 & 21 & 0.5 & 2.52 & 6.32 & 6.392404 \\
\hline R176 & 21 & 0.49 & 2.38 & 6.81 & 6.402442 \\
\hline R180 & 21 & 0.64 & 2.55 & 6.86 & 9.184901 \\
\hline R184 & 21 & 0.58 & 2.9 & 6.75 & 9.531376 \\
\hline R192 & 21 & 0.5 & 2.46 & 6.83 & 6.830104 \\
\hline R196 & 21 & 0.64 & 2.35 & 6.66 & 8.006021 \\
\hline R166 & 5 & 0.57 & 2.62 & 6.72 & 8.24494 \\
\hline R174 & 5 & 0.51 & 2.44 & 6.23 & 6.1504 \\
\hline R178 & 5 & 0.52 & 2.35 & 6.93 & 6.834832 \\
\hline R186 & 5 & 0.6 & 2.5 & 6.59 & 8.000044 \\
\hline R185 & Control & 0.34 & 2.65 & 6.7 & 4.968558 \\
\hline R189 & Control & 0.64 & 2.44 & 6.65 & 8.374021 \\
\hline R195 & Control & 0.61 & 2.49 & 6.72 & 8.290636 \\
\hline & & & & &
\end{tabular}


Table A6-b: Volume 2 Measurements and Average Measurement for each rabbit in Experiment 1

\begin{tabular}{|c|c|c|c|c|c|c|}
\hline \multirow[b]{2}{*}{ Rabbit \# } & \multicolumn{4}{|l|}{ Volume 2} & \multirow[b]{2}{*}{ V2 } & \multirow[b]{2}{*}{ Vaverage } \\
\hline & Nicotine Dose $(\mathrm{mg} / \mathrm{ml})$ & & L2 & $\mathrm{H} 2$ & & \\
\hline R179 & 10.5 & 0.54 & 2.63 & 6.51 & 7.549042 & 7.386934 \\
\hline R181 & 10.5 & 0.53 & 2.59 & 6.79 & 7.655589 & 7.357441 \\
\hline R187 & 10.5 & 0.54 & 2.56 & 6.68 & 7.537972 & 7.008288 \\
\hline R188 & 10.5 & 0.59 & 2.44 & 6.64 & 7.705404 & 7.71794 \\
\hline R191 & 10.5 & 0.85 & 2.33 & 6.57 & 10.34153 & 9.701075 \\
\hline R168 & 21 & 0.48 & 2.5 & 6.25 & 5.992036 & 6.19222 \\
\hline R176 & 21 & 0.49 & 2.58 & 6.78 & 7.031896 & 6.717169 \\
\hline R180 & 21 & 0.68 & 2.3 & 6.86 & 8.592757 & 8.888829 \\
\hline R184 & 21 & 0.43 & 2.87 & 6.8 & 7.040995 & 8.286186 \\
\hline R192 & 21 & 0.52 & 2.62 & 6.86 & 7.712436 & 7.27127 \\
\hline R196 & 21 & 0.68 & 2.28 & 6.61 & 8.111861 & 8.058941 \\
\hline R166 & 5 & 0.55 & 2.76 & 6.69 & 8.427544 & 8.336242 \\
\hline R174 & 5 & 0.42 & 2.51 & 6.21 & 5.227113 & 5.688756 \\
\hline R178 & 5 & 0.55 & 2.21 & 6.94 & 6.707694 & 6.771263 \\
\hline R186 & 5 & 0.62 & 2.75 & 6.57 & 9.254063 & 8.627053 \\
\hline R185 & Control & 0.44 & 2.54 & 6.69 & 6.094443 & 5.531501 \\
\hline R189 & Control & 0.65 & 2.28 & 6.67 & 7.842905 & 8.108463 \\
\hline R195 & Control & 0.62 & 2.52 & 6.73 & 8.567165 & 8.428901 \\
\hline
\end{tabular}

Table A6-c: Wet Wt. Measurements for each rabbit in Experiment 1

\begin{tabular}{|c|c|c|c|c|c|}
\hline & & Wet Wt & & & \\
\hline Rabbit \# & \begin{tabular}{|l} 
Nicotine \\
Dose \\
$(\mathrm{mg} / \mathrm{ml})$ \\
\end{tabular} & 1 & 2 & 3 & average \\
\hline R179 & 10.5 & 0.016 & 0.0161 & 0.0161 & 0.016067 \\
\hline R181 & 10.5 & 0.017 & 0.0167 & 0.0168 & 0.016833 \\
\hline R187 & 10.5 & 0.0145 & 0.0146 & 0.0145 & 0.014533 \\
\hline R188 & 10.5 & 0.0178 & 0.0178 & 0.0173 & 0.017633 \\
\hline R191 & 10.5 & 0.021 & 0.0211 & 0.0212 & 0.0211 \\
\hline R168 & 21 & 0.0138 & 0.014 & 0.0142 & 0.014 \\
\hline R176 & 21 & 0.0142 & 0.0144 & 0.0141 & 0.014233 \\
\hline R180 & 21 & 0.0179 & 0.0179 & 0.0179 & 0.0179 \\
\hline R184 & 21 & 0.0168 & 0.017 & 0.0168 & 0.016867 \\
\hline R192 & 21 & 0.0145 & 0.0143 & 0.0141 & 0.0143 \\
\hline R196 & 21 & 0.0174 & 0.0175 & 0.0174 & 0.017433 \\
\hline R166 & 5 & 0.0196 & 0.0193 & 0.0193 & 0.0194 \\
\hline R174 & 5 & 0.014 & 0.014 & 0.0138 & 0.013933 \\
\hline R178 & 5 & 0.0174 & 0.0172 & 0.017 & 0.0172 \\
\hline R186 & 5 & 0.0192 & 0.0196 & 0.019 & 0.019267 \\
\hline R185 & Control & 0.0125 & 0.0122 & 0.0126 & 0.012433 \\
\hline R189 & Control & 0.0171 & 0.0173 & 0.0175 & 0.0173 \\
\hline R195 & Control & 0.0188 & 0.0188 & 0.0188 & 0.0188 \\
\hline
\end{tabular}


Table A6-d: Defatted Wt. Measurements for each rabbit in Experiment 1

\begin{tabular}{|c|c|c|c|c|c|}
\hline & & Defatted V & & & \\
\hline Rabbit \# & \begin{tabular}{|l} 
Nicotine \\
Dose \\
$(\mathrm{mg} / \mathrm{ml})$ \\
\end{tabular} & 1 & 2 & 3 & average \\
\hline R179 & 10.5 & 0.0158 & 0.0165 & 0.0161 & 0.016133 \\
\hline R181 & 10.5 & 0.0164 & 0.016 & 0.0162 & 0.0162 \\
\hline R187 & 10.5 & 0.0148 & 0.0144 & 0.014 & 0.0144 \\
\hline R188 & 10.5 & 0.0167 & 0.0163 & 0.0164 & 0.016467 \\
\hline R191 & 10.5 & 0.0205 & 0.0205 & 0.0205 & 0.0205 \\
\hline R168 & 21 & 0.0135 & 0.0134 & 0.0138 & 0.013567 \\
\hline R176 & 21 & 0.0133 & 0.0132 & 0.0139 & 0.013467 \\
\hline R180 & 21 & 0.0179 & 0.0178 & 0.0173 & 0.017667 \\
\hline R184 & 21 & 0.0163 & 0.0165 & 0.0167 & 0.0165 \\
\hline R192 & 21 & 0.0139 & 0.0137 & 0.0139 & 0.013833 \\
\hline R196 & 21 & 0.017 & 0.0168 & 0.0165 & 0.016767 \\
\hline R166 & 5 & 0.0193 & 0.019 & 0.0192 & 0.019167 \\
\hline R174 & 5 & \begin{tabular}{l|l}
0.0128 \\
\end{tabular} & 0.0131 & 0.0131 & 0.013 \\
\hline R178 & 5 & 0.0163 & 0.0167 & 0.0168 & 0.0166 \\
\hline R186 & 5 & 0.0191 & 0.0188 & 0.0185 & 0.0188 \\
\hline R185 & Control & 0.0121 & 0.0127 & 0.0121 & 0.0123 \\
\hline R189 & Control & 0.0163 & 0.0171 & 0.0171 & 0.016833 \\
\hline R195 & Control & 0.0185 & 0.0185 & 0.0188 & 0.0186 \\
\hline
\end{tabular}

Table A6-e: Dry Wt. 1 \& 2 Measurements for each rabbit in Experiment 1

\begin{tabular}{|c|c|c|c|c|c|c|}
\hline & & Dry Wt 1 & & & & Dry Wt day 2 \\
\hline Rabbit \# & $\begin{array}{l}\text { Nicotine } \\
\text { Dose } \\
(\mathrm{mg} / \mathrm{ml})\end{array}$ & 1 & 2 & 3 & average & 1 \\
\hline R179 & 10.5 & 0.0142 & 0.0148 & 0.0145 & 0.0145 & 0.0145 \\
\hline R181 & 10.5 & 0.0148 & 0.0154 & 0.0158 & 0.015333 & 0.0151 \\
\hline R187 & 10.5 & 0.0131 & 0.013 & 0.0132 & 0.0131 & 0.013 \\
\hline R188 & 10.5 & 0.0155 & 0.0157 & 0.0155 & 0.015567 & 0.0158 \\
\hline R191 & 10.5 & 0.0182 & 0.0189 & 0.0188 & 0.018633 & 0.0189 \\
\hline R168 & 21 & 0.0125 & 0.0126 & 0.0132 & 0.012767 & 0.0125 \\
\hline R176 & 21 & 0.0125 & 0.0124 & 0.0128 & 0.012567 & 0.0124 \\
\hline R180 & 21 & 0.0163 & 0.016 & 0.0164 & 0.016233 & 0.0166 \\
\hline R184 & 21 & 0.0157 & 0.0155 & 0.0159 & 0.0157 & 0.0158 \\
\hline R192 & 21 & 0.0126 & 0.013 & 0.013 & 0.012867 & 0.0134 \\
\hline R196 & 21 & 0.0154 & 0.0156 & 0.0158 & 0.0156 & 0.0156 \\
\hline $\mathrm{R} 166$ & 5 & 0.0181 & 0.0184 & 0.0184 & 0.0183 & 0.0181 \\
\hline R174 & 5 & 0.0129 & 0.0124 & 0.0131 & 0.0128 & 0.0127 \\
\hline R178 & 5 & 0.0159 & 0.0151 & 0.0159 & 0.015633 & 0.0156 \\
\hline R186 & 5 & 0.0171 & 0.0174 & 0.0177 & 0.0174 & 0.0172 \\
\hline R185 & Control & 0.0108 & 0.0115 & 0.0111 & 0.011133 & 0.0111 \\
\hline R189 & Control & 0.0158 & 0.0161 & 0.0158 & 0.0159 & 0.0157 \\
\hline R195 & Control & 0.0175 & 0.0174 & 0.017 & 0.0173 & 0.017 \\
\hline
\end{tabular}


Table A6-f: Ash Wt. Measurements for each rabbit in Experiment 1

\begin{tabular}{|l|r|r|r|r|r|}
\hline & \multicolumn{3}{|l|}{ Ash Wt } & & \\
\hline & $\begin{array}{l}\text { Nicotine } \\
\text { Dose } \\
\text { Rabbit \# }\end{array}$ & $\mathbf{m g}$ ) & $\mathbf{1}$ & $\mathbf{2}$ & $\mathbf{3}$ \\
average \\
\hline R179 & 10.5 & 0.011 & 0.0113 & 0.011 & 0.0111 \\
\hline R181 & 10.5 & 0.0108 & 0.0111 & 0.0112 & 0.011033 \\
\hline R187 & 10.5 & 0.0098 & 0.0101 & 0.0101 & 0.01 \\
\hline R188 & 10.5 & 0.0111 & 0.0117 & 0.0115 & 0.011433 \\
\hline R191 & 10.5 & 0.0137 & 0.0135 & 0.0137 & 0.013633 \\
\hline R168 & 21 & 0.0088 & 0.0091 & 0.009 & 0.008967 \\
\hline R176 & 21 & 0.0096 & 0.0093 & 0.0093 & 0.0094 \\
\hline R180 & 21 & 0.0124 & 0.0121 & 0.012 & 0.012167 \\
\hline R184 & 21 & 0.0111 & 0.0111 & 0.0113 & 0.011167 \\
\hline R192 & 21 & 0.0095 & 0.0093 & 0.0096 & 0.009467 \\
\hline R196 & 21 & 0.0116 & 0.0114 & 0.0114 & 0.011467 \\
\hline R166 & 5 & 0.0131 & 0.0134 & 0.0132 & 0.013233 \\
\hline R174 & 5 & 0.0094 & 0.0094 & 0.0094 & 0.0094 \\
\hline R178 & 5 & 0.0116 & 0.0115 & 0.0115 & 0.011533 \\
\hline R186 & 5 & 0.0124 & 0.0127 & 0.0124 & 0.0125 \\
\hline R185 & Control & 0.0078 & 0.0078 & 0.0078 & 0.0078 \\
\hline R189 & Control & 0.0117 & 0.0118 & 0.0119 & 0.0118 \\
\hline R195 & Control & 0.0123 & 0.0122 & 0.0124 & 0.0123 \\
\hline
\end{tabular}

Table A6-g: Composition. Measurements for each rabbit in Experiment 1

\begin{tabular}{|l|r|l|l|l|l|l|r|r|}
\hline $\begin{array}{l}\text { Rabbit } \\
\text { Number }\end{array}$ & $\begin{array}{l}\text { Nicotine } \\
\text { Dose } \\
(\mathbf{m g} / \mathbf{m l})\end{array}$ & $\begin{array}{l}\text { Wet } \\
\text { Density }\end{array}$ & $\begin{array}{l}\text { Dry } \\
\text { Density }\end{array}$ & \% Min & $\begin{array}{l}\% \text { Org } \\
\text { (Dry) }\end{array}$ & \%Ash & $\begin{array}{l}\% \text { Org } \\
\text { (wet) }\end{array}$ & $\%$ Water \\
\hline R179 & 10.5 & 0.00218 & 0.00196 & 76.552 & 23.448 & 69.087 & 21.162 & 9.751037 \\
\hline R181 & 10.5 & 0.00229 & 0.00208 & 71.957 & 28.043 & 65.545 & 25.545 & 8.910891 \\
\hline R187 & 10.5 & 0.00207 & 0.00187 & 76.336 & 23.664 & 68.807 & 21.33 & 9.862385 \\
\hline R188 & 10.5 & 0.00228 & 0.00202 & 73.448 & 26.552 & 64.839 & 23.44 & 11.72023 \\
\hline R191 & 10.5 & 0.00218 & 0.00192 & 73.166 & 26.834 & 64.613 & 23.697 & 11.69036 \\
\hline R168 & 21 & 0.00226 & 0.00206 & 70.235 & 29.765 & 64.048 & 27.143 & 8.809524 \\
\hline R176 & 21 & 0.00212 & 0.00187 & 74.801 & 25.199 & 66.042 & 22.248 & 11.7096 \\
\hline R180 & 21 & 0.00201 & 0.00183 & 74.949 & 25.051 & 67.97 & 22.719 & 9.310987 \\
\hline R184 & 21 & 0.00204 & 0.00189 & 71.125 & 28.875 & 66.206 & 26.877 & 6.916996 \\
\hline R192 & 21 & 0.00197 & 0.00177 & 73.575 & 26.425 & 66.2 & 23.776 & 10.02331 \\
\hline R196 & 21 & 0.00216 & 0.00194 & 73.504 & 26.496 & 65.774 & 23.709 & 10.51625 \\
\hline R166 & 5 & 0.00233 & 0.0022 & 72.313 & 27.687 & 68.213 & 26.117 & 5.670103 \\
\hline R174 & 5 & 0.00245 & 0.00225 & 73.438 & 26.563 & 67.464 & 24.402 & 8.133971 \\
\hline R178 & 5 & 0.00254 & 0.00231 & 73.774 & 26.226 & 67.054 & 23.837 & 9.108527 \\
\hline R186 & 5 & 0.00223 & 0.00202 & 71.839 & 28.161 & 64.879 & 25.433 & 9.688581 \\
\hline R185 & Control & 0.00225 & 0.00201 & 70.06 & 29.94 & 62.735 & 26.81 & 10.45576 \\
\hline R189 & Control & 0.00213 & 0.00196 & 74.214 & 25.786 & 68.208 & 23.699 & 8.092486 \\
\hline R195 & Control & 0.00223 & 0.00205 & 71.098 & 28.902 & 65.426 & 26.596 & 7.978723 \\
\hline
\end{tabular}


Table A7-a: Porosity and radius size measurement for each rabbit in Experiment 1

\begin{tabular}{|l|r|r|r|}
\hline & $\begin{array}{l}\text { Nicotine } \\
\text { Dose } \\
(\mathbf{m g} / \mathrm{ml})\end{array}$ & $\%$ Porosity & $\begin{array}{l}\text { average } \\
\text { area pore } \\
\text { size um }\end{array}$ \\
\hline R179 & 10.5 & 0.02183724 & 14.84612 \\
\hline R181 & 10.5 & 0.02341927 & 13.9448 \\
\hline R187 & 10.5 & 0.01548242 & 12.87641 \\
\hline R188 & 10.5 & 0.0093724 & 12.9025 \\
\hline R191 & 10.5 & 0.00581641 & 12.1727 \\
\hline R168 & 21 & 0.01834635 & 11.32048 \\
\hline R176 & 21 & 0.02533464 & 13.65804 \\
\hline R180 & 21 & 0.01304427 & 12.70747 \\
\hline R184 & 21 & 0.00818555 & 13.25417 \\
\hline R192 & 21 & 0.01014583 & 13.34112 \\
\hline R196 & 21 & 0.00888737 & 13.7954 \\
\hline R166 & 5 & 0.00777865 & 12.71318 \\
\hline R174 & 5 & 0.03040625 & 13.01157 \\
\hline R178 & 5 & 0.01054622 & 14.89447 \\
\hline R186 & 5 & 0.01772656 & 13.30664 \\
\hline R185 & Control & 0.01293359 & 14.04367 \\
\hline R189 & Control & 0.00805013 & 12.45012 \\
\hline R195 & Control & 0.01526172 & 15.84647 \\
\hline
\end{tabular}




\section{Appendix B}

Table B1-a: Weight and Nicotine measurements for every rabbit in Experiment 2

\begin{tabular}{|c|c|c|c|c|c|c|c|c|}
\hline Rabbit \# & Group & $\begin{array}{l}\text { Surgery } \\
\text { Date }\end{array}$ & \begin{tabular}{|l} 
Sacurfice \\
Date
\end{tabular} & $\begin{array}{l}\text { Starting } \\
\text { Weight } \\
(\mathrm{kg})\end{array}$ & \begin{tabular}{|l|} 
Week 1 \\
Weight
\end{tabular} & \begin{tabular}{|l|} 
Week 3 \\
Weight
\end{tabular} & $\begin{array}{l}\text { Week } 5 \\
\text { Weight }\end{array}$ & $\begin{array}{l}\text { Weight } \\
\text { Difference } \\
(\mathrm{kg})\end{array}$ \\
\hline 289 & Control & $2 / 16 / 2004$ & $3 / 22 / 2004$ & 3.6 & 3.5 & 3.52 & 3.57 & 0.03 \\
\hline 290 & Control & $2 / 16 / 2004$ & $3 / 22 / 2004$ & 4.4 & 4.3 & 4.27 & 4.18 & 0.22 \\
\hline 291 & Nicotine & $2 / 17 / 2004$ & $3 / 23 / 2004$ & 4.6 & 4.5 & 4.53 & 4.57 & 0.03 \\
\hline 292 & Nicotine & $2 / 17 / 2004$ & $3 / 23 / 2004$ & 3.7 & 3.54 & 3.65 & 3.54 & 0.16 \\
\hline 293 & Control & $2 / 9 / 2004$ & $3 / 15 / 2004$ & 4.5 & & 4.2 & 4.11 & 0.39 \\
\hline 294 & Nicotine & $2 / 26 / 2004$ & $4 / 1 / 2004$ & 4.2 & 4.13 & 4.32 & 4.33 & -0.13 \\
\hline 295 & Nicotine & 2/17/2004 & $3 / 23 / 2004$ & 5.2 & 4.96 & 4.92 & 4.76 & 0.44 \\
\hline 296 & Nicotine & 2/18/2004 & $3 / 24 / 2004$ & 4.5 & 4.33 & 4.13 & 4.03 & 0.47 \\
\hline 297 & Nicotine & $2 / 18 / 2004$ & $3 / 24 / 2004$ & 4.3 & 4.28 & 4.04 & 3.9 & 0.4 \\
\hline 298 & Nicotine & 2/19/2004 & $3 / 25 / 2004$ & 4.9 & 4.69 & 4.73 & 4.58 & 0.32 \\
\hline 300 & Nicotine & $2 / 19 / 2004$ & $3 / 25 / 2004$ & 4.2 & 4.01 & 3.97 & 3.74 & 0.46 \\
\hline 301 & Control & $2 / 20 / 2004$ & $3 / 26 / 2004$ & 4.4 & 4.14 & 4.05 & 4.09 & 0.31 \\
\hline 303 & Control & 2/20/2004 & $3 / 26 / 2004$ & 3.8 & 3.65 & 3.5 & 3.56 & 0.24 \\
\hline 304 & 4 Week \$ & $2 / 24 / 2004$ & $3 / 30 / 2004$ & 4.5 & 4.23 & 3.99 & 3.84 & 0.66 \\
\hline 305 & 4 Week & $2 / 24 / 2004$ & $3 / 30 / 2004$ & 4.4 & 4.36 & 4.12 & 3.98 & 0.42 \\
\hline 306 & 4 Week & $2 / 24 / 2004$ & $3 / 30 / 2004$ & 5.1 & 4.7 & 4.64 & 4.58 & 0.52 \\
\hline 307 & 4 Week & $2 / 25 / 2004$ & $3 / 31 / 2004$ & 3.93 & 3.91 & 3.56 & 3.38 & 0.55 \\
\hline 308 & 4 Week $\$$ & $2 / 25 / 2004$ & $3 / 31 / 2004$ & 4.23 & 4.17 & 3.96 & 3.77 & 0.46 \\
\hline 309 & 4 Week & $2 / 25 / 2004$ & $3 / 31 / 2004$ & 4 & 4 & 3.8 & 3.71 & 0.29 \\
\hline 310 & Nicotine & 2/26/2004 & $4 / 1 / 2004$ & 4.4 & 4.19 & 3.9 & 3.71 & 0.69 \\
\hline $\mathrm{F} 1$ & 5 Week & $4 / 12 / 2004$ & $5 / 17 / 2004$ & 3.68 & 3.44 & 3.44 & 3.45 & 0.23 \\
\hline F3 & 5 Week & $4 / 12 / 2004$ & $5 / 17 / 2004$ & 4.13 & 3.87 & 3.83 & 3.85 & 0.28 \\
\hline $\mathrm{F} 4$ & 5 Week & $4 / 12 / 2004$ & $5 / 17 / 2004$ & 4.29 & 4.13 & 3.89 & 3.83 & 0.46 \\
\hline F6 & 5 Week $\$$ & $4 / 14 / 2004$ & $5 / 19 / 2004$ & 4.32 & 4.12 & 3.97 & 3.88 & 0.44 \\
\hline F7 & 5 Week & $4 / 14 / 2004$ & $5 / 19 / 2004$ & 4.07 & 3.88 & 3.75 & 3.61 & 0.46 \\
\hline F8 & 5 Week & $4 / 14 / 2004$ & $5 / 19 / 2004$ & 4.36 & 3.91 & 3.7 & 3.68 & 0.68 \\
\hline
\end{tabular}


Table B1-b: Weight and Nicotine measurements for every rabbit in Experiment 2

\begin{tabular}{|c|c|c|c|c|c|c|c|}
\hline Rabbit \# & Group & \begin{tabular}{|l} 
Nicotine \\
Full \\
(Days)
\end{tabular} & \begin{tabular}{|l|} 
Nicotine \\
$1 / 2$ one \\
patch on \\
of the 2 \\
(Davs) \\
\end{tabular} & \begin{tabular}{|l|} 
Nicotine \\
patch off \\
(days)
\end{tabular} & \begin{tabular}{|l|} 
Nicotine \\
Serum \\
level 1 \\
week
\end{tabular} & \begin{tabular}{|l|} 
Nicotine \\
Serum \\
level 3 \\
weeks
\end{tabular} & \begin{tabular}{|l} 
Nicotine \\
Serum \\
level 5 \\
weeks
\end{tabular} \\
\hline 289 & Control & $x$ & $x$ & $\mathrm{x}$ & 0 & 0 & 0 \\
\hline 290 & Control & $x$ & $\mathrm{x}$ & $\mathrm{x}$ & 0 & 0 & $\underline{0}$ \\
\hline 291 & Nicotine & 14 & 8 & 13 & 200 & 92 & 0 \\
\hline 292 & Nicotine & 13 & 11 & 11 & 47 & 180 & 0 \\
\hline 293 & Control & $x$ & $x$ & $x$ & 0 & 0 & 0 \\
\hline 294 & Nicotine & 24 & 8 & 2 & 40 & 96 & 24 \\
\hline 295 & Nicotine & 16 & 14 & 3 & 140 & 120 & 11 \\
\hline 296 & Nicotine & 28 & 7 & 0 & 44 & 75 & 30 \\
\hline 297 & Nicotine & 29 & 6 & 0 & 18 & 99 & 82 \\
\hline 298 & Nicotine & 28 & 6 & 1 & 70 & 100 & 40 \\
\hline 300 & Nicotine & 15 & 19 & 1 & $?$ & 72 & 33 \\
\hline 301 & Control & $x$ & $x$ & $x$ & 0 & 0 & 0 \\
\hline 303 & Control & $x$ & $x$ & $x$ & 0 & 0 & 0 \\
\hline 304 & 4 Week Smoking & $x$ & $x$ & $\mathrm{x}$ & 0 & 17 & 0 \\
\hline 305 & 4 Week Smoking & $x$ & $x$ & $x$ & 0 & 20 & 5.5 \\
\hline 306 & 4 Week Smoking & $x$ & $x$ & $x$ & 0 & 21 & 5.8 \\
\hline 307 & 4 Week Smoking & $x$ & $x$ & $x$ & 0 & 35 & 6.9 \\
\hline 308 & 4 Week Smoking & $x$ & $x$ & $x$ & 0 & 19 & 6.7 \\
\hline 309 & 4 Week Smoking & $x$ & $x$ & $x$ & $?$ & $?$ & 10 \\
\hline 310 & Nicotine & 22 & 13 & 0 & 37 & 130 & 32 \\
\hline $\mathrm{F} 1$ & 5 Week Smoking & $x$ & $x$ & $x$ & 26 & 26 & 8.2 \\
\hline F3 & 5 Week Smoking & $x$ & $x$ & $x$ & 32 & 22 & 5.9 \\
\hline $\mathrm{F} 4$ & 5 Week Smoking & $x$ & $x$ & $x$ & 8.7 & 24 & 0 \\
\hline F6 & 5 Week Smoking & $x$ & $x$ & $x$ & 9 & 11 & 0 \\
\hline F7 & 5 Week Smoking & $x$ & $x$ & $x$ & 25 & 9.7 & 0 \\
\hline F8 & 5 Week Smoking & $x$ & $x$ & $x$ & $?$ & 110 & 6.8 \\
\hline
\end{tabular}


Table B1-c: Weight and Nicotine measurements for every rabbit in Experiment 2

\begin{tabular}{|c|c|c|c|c|}
\hline Rabbit \# & Group & $\begin{array}{l}\text { Average } \\
\text { nicotine } \\
\text { level }\end{array}$ & $\begin{array}{l}\text { Max } \\
\text { nicotine } \\
\text { level }\end{array}$ & $\begin{array}{l}\text { Min } \\
\text { Nicotine } \\
\text { Level }\end{array}$ \\
\hline 289 & Control & 0 & 0 & 0 \\
\hline 290 & Control & 0 & 0 & 0 \\
\hline 291 & Nicotine & 97.33333 & 200 & 0 \\
\hline 292 & Nicotine & 75.66667 & 180 & 0 \\
\hline 293 & Control & 0 & 0 & 0 \\
\hline 294 & Nicotine & 53.33333 & 96 & 24 \\
\hline 295 & Nicotine & 90.33333 & 140 & 11 \\
\hline 296 & Nicotine & 49.66667 & 75 & 30 \\
\hline 297 & Nicotine & 66.33333 & 99 & 18 \\
\hline 298 & Nicotine & 70 & 100 & 40 \\
\hline 300 & Nicotine & 35 & 72 & $\underline{0}$ \\
\hline 301 & Control & 0 & 0 & $\underline{0}$ \\
\hline 303 & Control & 0 & 0 & 0 \\
\hline 304 & 4 Week Smoking & 5.666667 & 17 & 0 \\
\hline 305 & 4 Week Smoking & 8.5 & 20 & 0 \\
\hline 306 & 4 Week Smoking & 8.933333 & 21 & 0 \\
\hline 307 & 4 Week Smoking & 13.96667 & 35 & 0 \\
\hline 308 & 4 Week Smoking & 8.566667 & 19 & 0 \\
\hline 309 & 4 Week Smoking & 3.333333 & 10 & $\underline{0}$ \\
\hline 310 & Nicotine & 66.33333 & 130 & 32 \\
\hline $\mathrm{F} 1$ & 5 Week Smoking & 20.06667 & 26 & 8.2 \\
\hline F3 & 5 Week Smoking & 19.96667 & 32 & 5.9 \\
\hline F4 & 5 Week Smoking & 10.9 & 24 & 0 \\
\hline F6 & 5 Week Smoking & 6.666667 & 11 & $\underline{0}$ \\
\hline F7 & 5 Week Smoking & 11.56667 & 25 & $\underline{0}$ \\
\hline F8 & 5 Week Smoking & 58.4 & 110 & 6.8 \\
\hline
\end{tabular}


Table B2-a: Fracture toughness measurement and values for each rabbit in Experiment 2

\begin{tabular}{|c|c|c|c|c|c|}
\hline 291 & Nicotine & 0.00057 & 0.0028 & 0.00538 & 0.51115 \\
\hline 292 & Nicotine & 0.00062 & 0.003 & 0.00543 & 0.54696 \\
\hline 293 & Control & 0.00068 & 0.0029 & 0.00585 & 0.48889 \\
\hline 294 & Nicotine & 0.00054 & 0.0029 & 0.005 & 0.57 \\
\hline 295 & Nicotine & 0.00062 & 0.0021 & 0.00541 & 0.38078 \\
\hline 296 & Nicotine & 0.00053 & 0.0028 & 0.0052 & 0.52885 \\
\hline 297 & Nicotine & 0.0005 & 0.0031 & 0.0056 & 0.55714 \\
\hline 298 & Nicotine & 0.00053 & 0.003 & 0.00576 & 0.51736 \\
\hline 300 & Nicotine & 0.00049 & 0.0022 & 0.00535 & 0.41869 \\
\hline 301 & Control & 0.0007 & 0.0037 & 0.0057 & 0.65439 \\
\hline 303 & Control & 0.00053 & 0.0032 & 0.00558 & 0.56989 \\
\hline 304 & 4 Week Sm & 0.00061 & 0.003 & 0.00569 & 0.53427 \\
\hline 305 & 4 Week Smoking & 0.00058 & 0.0027 & 0.00539 & 0.50278 \\
\hline 306 & 4 Week Smoking & 0.00045 & 0.0029 & 0.00539 & 0.53061 \\
\hline 307 & 4 Week Smoking & 0.00061 & 0.0028 & 0.00553 & 0.49729 \\
\hline 308 & 4 Week Sm & 0.00049 & 0.003 & 0.0054 & 0.55556 \\
\hline 309 & 4 Week Sm & 0.00054 & 0.0032 & 0.00531 & 0.60452 \\
\hline 310 & Nicotine & 0.00075 & 0.0031 & 0.00524 & 0.58397 \\
\hline $\mathrm{F} 1$ & 5 Week Smoking & 0.00046 & 0.0022 & 0.00507 & 0.42406 \\
\hline F3 & 5 Week Smoking & 0.0006 & 0.0026 & 0.00566 & 0.45406 \\
\hline F4 & 5 Week Smoking & 0.00052 & 0.0028 & 0.00546 & 0.50916 \\
\hline F6 & 5 Week Smoking & 0.00044 & 0.0026 & 0.00542 & 0.4834 \\
\hline $\mathrm{F} 7$ & 5 Week Smoking & 0.00053 & 0.0027 & 0.0051 & 0.52745 \\
\hline F8 & 5 Week Smoking & 0.00052 & 0.0022 & 0.00523 & 0.42639 \\
\hline
\end{tabular}


Table B2-b: Fracture toughness measurement and values for each rabbit in Experiment 2

\begin{tabular}{|c|c|c|c|c|c|c|}
\hline Rabbit \# & Group & $f(a / W)$ & $\begin{array}{l}\text { Max } \\
\operatorname{Load}(\mathrm{N})\end{array}$ & $\mathrm{Kc}\left(\mathrm{Nm}^{\wedge}-3 / 2\right)$ & $\begin{array}{l}\mathrm{Kc} \\
\left(\mathrm{MNm}^{\wedge}-\right. \\
3 / 2)\end{array}$ & $\begin{array}{l}\text { Complinace } \\
\text { Slope } \\
\text { Inverse } \\
\end{array}$ \\
\hline 289 & Control & 11.8757 & 6.6192 & 2009213 & 2.009213 & 2.6645 \\
\hline 290 & Control & 12.2754 & 4.2931 & 1381692 & 1.381692 & 3.037 \\
\hline 291 & Nicotine & 9.93253 & 5.8828 & 1397584 & 1.397584 & 2.4437 \\
\hline 292 & Nicotine & 11.1452 & 8.9424 & 2181481 & 2.181481 & 1.937 \\
\hline 293 & Control & 9.29451 & 5.787 & 1034172 & 1.034172 & 3.357 \\
\hline 294 & Nicotine & 12.082 & 3.3201 & 1050533 & 1.050533 & 5.12 \\
\hline 295 & Nicotine & 6.98519 & 9.0861 & 1391764 & 1.391764 & 2.219 \\
\hline 296 & Nicotine & 10.4993 & 4.0446 & 1111111 & 1.111111 & 3.11 \\
\hline 297 & Nicotine & 11.5419 & 5.0236 & 1549631 & 1.549631 & 3.408 \\
\hline 298 & Nicotine & 10.1248 & 6.0624 & 1525967 & 1.525967 & 2.92 \\
\hline 300 & Nicotine & 7.67883 & 3.3291 & 713262.1 & 0.713262 & 4.117 \\
\hline 301 & Control & 17.1233 & 10.3195 & 3343561 & 3.343561 & 1.85 \\
\hline 303 & Control & 12.0772 & 6.8559 & 411 & 2.09 & 2.467 \\
\hline 304 & 4 Week Smoking & 10.6852 & 6.733 & 3531 & 1.563531 & 2.212 \\
\hline 305 & 4 Week Sn & 9.68365 & 5.281 & 973 & 1.200973 & 2.789 \\
\hline 306 & 4 Week Sm & 10.5592 & 4.6673 & 722 & 1.491722 & 3.322 \\
\hline 307 & 4 Week Smoking & 9.52631 & 7.6132 & 8820 & 1.59882 & 2.78 \\
\hline 308 & 4 Week Smoking & 11.4783 & 5.3559 & 1707334 & 1.707334 & 3.201 \\
\hline 309 & 4 Week Smoking & 13.7885 & 5.9935 & 2100181 & 2.100181 & 2.256 \\
\hline 310 & Nicotine & 12.724 & 7.6671 & 1796917 & 1.796917 & 2.18 \\
\hline $\mathrm{F} 1$ & 5 Week Smoking & 7.7859 & 3.4668 & 824092 & 0.824092 & 4.31 \\
\hline F3 & 5 Week Smoking & 8.42976 & 3.347 & 625044.9 & 0.625045 & 3.606 \\
\hline $\mathrm{F} 4$ & 5 Week Smoking & 9.87216 & 5.1463 & 1322232 & 1.322232 & 2.653 \\
\hline F6 & 5 Week Smoking & 9.1482 & 3.6524 & 1031482 & 1.031482 & 3.824 \\
\hline $\mathrm{F} 7$ & 5 Week Smoking & 10.4524 & 5.2361 & 1445986 & 1.445986 & 2.426 \\
\hline F8 & 5 Week Smoking & 7.83293 & 3.1075 & 647263.5 & 0.647263 & 3.388 \\
\hline
\end{tabular}


Table B3-a: Porosity for Experiment 2

\begin{tabular}{|c|c|c|}
\hline Rabbit \# & Porosity & Radius \\
\hline 289 & 0.010210 & 12.689917 \\
\hline 290 & 0.007767 & 12.085333 \\
\hline 291 & 0.012204 & 14.102859 \\
\hline 292 & 0.015241 & 14.804247 \\
\hline 293 & 0.014126 & 12.576312 \\
\hline 294 & 0.010340 & 11.195685 \\
\hline 295 & 0.013753 & 13.860507 \\
\hline 296 & 0.009671 & 11.969880 \\
\hline 297 & 907 & 12.712015 \\
\hline 298 & 641 & 3.212694 \\
\hline 300 & 29 & 6483 \\
\hline 301 & 0.0 & 2799 \\
\hline 303 & 0.0 & 2.639387 \\
\hline 304 & 507 & 12.679905 \\
\hline 305 & 660 & 12.966466 \\
\hline 306 & 0.012391 & 11.698264 \\
\hline 307 & 0.013550 & 12.869522 \\
\hline 308 & 0.007828 & 10.363446 \\
\hline 309 & 0.008495 & 12.402669 \\
\hline 310 & 549 & 12.011041 \\
\hline $\mathrm{F} 1$ & 653 & 13.81530727 \\
\hline F3 & 0.012558 & 13.64026948 \\
\hline $\mathrm{F} 4$ & 566 & 15.84608063 \\
\hline F6 & 0.010317 & 14.20458625 \\
\hline $\mathrm{F7}$ & 654 & 12.86125989 \\
\hline F8 & 0.014527 & 13.0642382 \\
\hline
\end{tabular}

